ArgOn national laboratory

ANL-AFCl-183

\title{
Advanced Burner Reactor Preliminary NEPA Data Study
}

Nuclear Engineering Division 


\begin{abstract}
About Argonne National Laboratory
Argonne is a U.S. Department of Energy laboratory managed by UChicago Argonne, LLC under contract DE-AC02-06CH11357. The Laboratory's main facility is outside Chicago, at 9700 South Cass Avenue, Argonne, Illinois 60439. For information about Argonne, see www.anl.gov.
\end{abstract}

\title{
Availability of This Report
}

This report is available, at no cost, at http://www.osti.gov/bridge. It is also available on paper to the U.S. Department of Energy and its contractors, for a processing fee, from:

U.S. Department of Energy

Office of Scientific and Technical Information

P.O. Box 62

Oak Ridge, TN 37831-0062

phone (865) 576-8401

fax (865) 576-5728

reports@adonis.osti.gov

\begin{abstract}
Disclaimer
This report was prepared as an account of work sponsored by an agency of the United States Government. Neither the United States Government nor any agency thereof, nor UChicago Argonne, LLC, nor any of their employees or officers, makes any warranty, express or implied, or assumes any legal liability or responsibility for the accuracy, completeness, or usefulness of any information, apparatus, product, or process disclosed, or represents that its use would not infringe privately owned rights. Reference herein to any specific commercial product, process, or service by trade name, trademark, manufacturer, or otherwise, does not necessarily constitute or imply its endorsement, recommendation, or favoring by the United States Government or any agency thereof. The views and opinions of document authors expressed herein do not necessarily state or reflect those of the United States Government or any agency thereof, Argonne National Laboratory, or UChicago Argonne, LLC.
\end{abstract}




\section{Advanced Burner Reactor Preliminary NEPA Data Study}

by

L. L. Briggs, J. E. Cahalan, L. W. Deitrich, T. H. Fanning, C. Grandy, R. Kellogg, T. K. Kim, and W. S. Yang Nuclear Engineering Division, Argonne National Laboratory

September 21, 2007

work sponsored by

U. S. Department of Energy,

Office of Nuclear Energy, Science and Technology

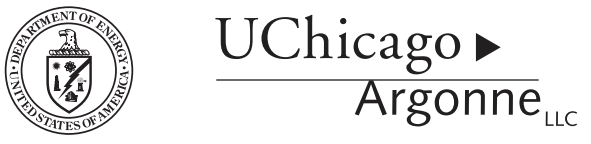





\section{Table of Contents}

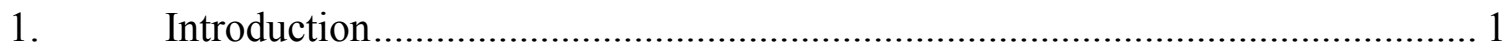

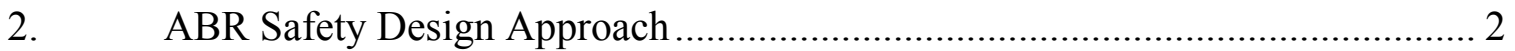

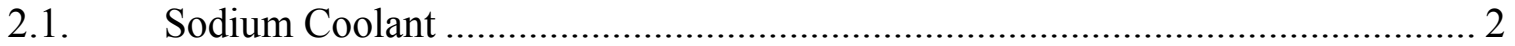

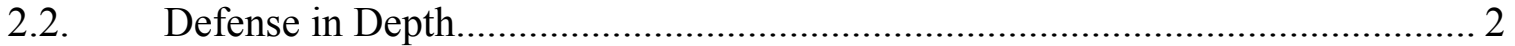

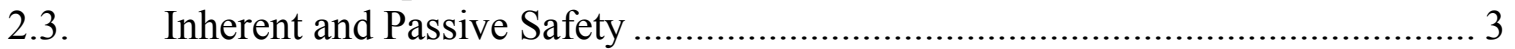

2.4. Sodium-Cooled Reactor Operating Experience.................................................. 5

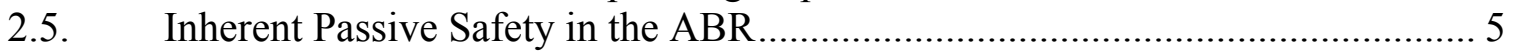

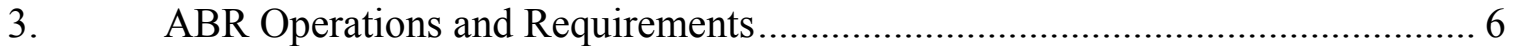

$3.1 \quad$ Fissile Material Inventory …………………............................................ 10

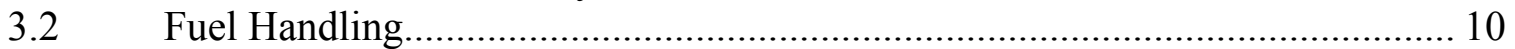

3.3 Facility Requirements .............................................................................. 13

3.3.1 Industrial Security and Safeguards ............................................................. 13

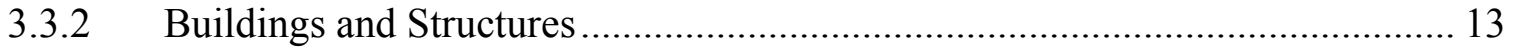

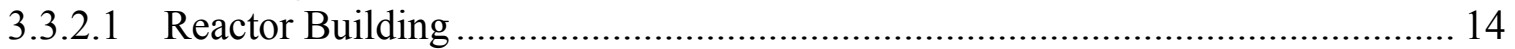

3.3.2.2 Balance of Plant Building .......................................................................... 17

3.3.2.3 Control Room and Personnel Building .......................................................... 17

3.3.2.4 Radwaste/Maintenance Building …………................................................. 17

3.3.2.5 Security Gate House .......................................................................... 18

3.3.2.6 Emergency Generator Buildings ............................................................. 18

3.3.2.7 Balance of Plant Services Building................................................................. 18

3.3.2.8 Lift Station Building and Wastewater Treatment Plant Building ...................... 18

3.3.2.9 Fuel Handling Facility Building ……………............................................. 19

3.3.2.10 Fuel Storage Facility Building ……………............................................ 19

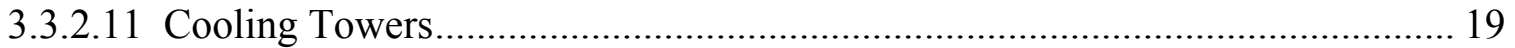

3.3.3 Radioactive and Hazardous Wastes from Operations........................................ 20

3.3.4 Non-hazardous Operations Wastes ............................................................... 21

3.3.5 Annual Operations Data............................................................................. 21

4. Summary of Nuclear Materials, Wastes, Effluents, Emissions, and Utilities during Operations and Construction .............................................................. 25

4.1 High-level Waste/Spent Nuclear Fuel ......................................................... 25

$4.2 \quad$ Effluents from Operations.......................................................................... 25

4.3 Air Emissions from Operations …………………..................................... 27

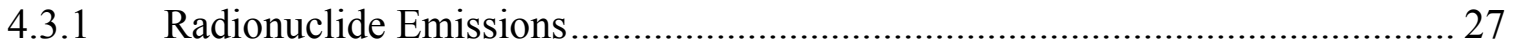

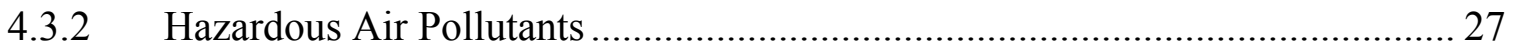

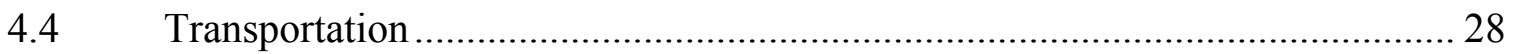

4.4.1 Transportation Data for Shipment of Wastes................................................... 28

4.4.2 Physics Data for Transportation of Spent Startup Driver Fuel .......................... 28

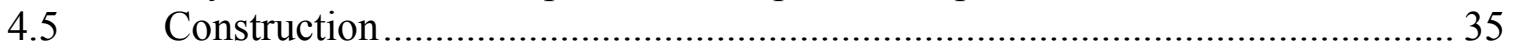

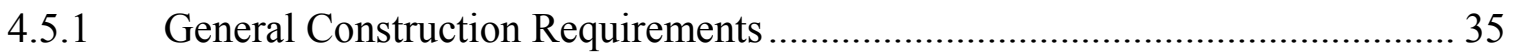

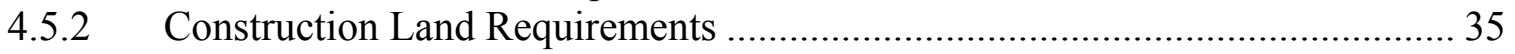

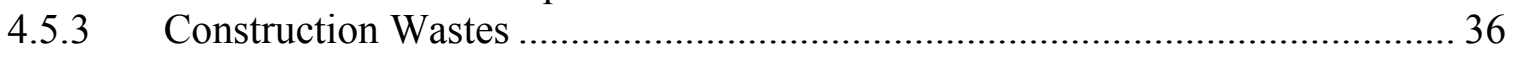

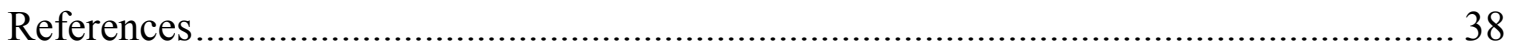

Appendix A: Bases for Data Presented........................................................................ 41 
ANL-AFCI-183, Rev. 0.5

Preliminary NEPA Data Study

Argonne

National laboratory

Appendix B: ABR Construction Wastes Spreadsheet Tables...................................... 70

Appendix C: ABR Plant Steel Requirements Spreadsheet Table ................................... 75 
1. Introduction

The Global Nuclear Energy Partnership (GNEP) is a new nuclear fuel cycle paradigm with the goals of expanding the use of nuclear power both domestically and internationally, addressing nuclear waste management concerns, and promoting nonproliferation. A key aspect of this program is fast reactor transmutation, in which transuranics recovered from light water reactor spent fuel are to be recycled to create fast reactor transmutation fuels. The benefits of these fuels are to be demonstrated in an Advanced Burner Reactor (ABR), which will provide a representative environment for recycle fuel testing, safety testing, and modern fast reactor design and safeguard features.

Because the GNEP programs will require facilities which may have an impact upon the environment within the meaning of the National Environmental Policy Act of 1969 (NEPA), preparation of a Programmatic Environmental Impact Statement (PEIS) for GNEP is being undertaken by Tetra Tech, Inc. The PEIS will include a section on the ABR. In support of the PEIS, the Nuclear Engineering Division of Argonne National Laboratory has been asked to provide a description of the ABR alternative, including graphics, plus estimates of construction and operations data for an ABR plant. The compilation of this information is presented in the remainder of this report.

Currently, DOE has started the process of engaging industry on the design of an Advanced Burner Reactor. Therefore, there is no specific, current, vendor-produced ABR design that could be used for this PEIS datacall package. In addition, candidate sites for the ABR vary widely as to available water, geography, etc. Therefore, ANL has based its estimates for construction and operations data largely on generalization of available information from existing plants and from the environmental report assembled for the Clinch River Breeder Reactor Plant (CRBRP) design [CRBRP, 1977]. The CRBRP environmental report was chosen as a resource because it thoroughly documents the extensive evaluation which was performed on the anticipated environmental impacts of that plant. This source can be referenced in the open literature and is publicly available. The CRBRP design was also of a commercial demonstration plant size - 975 MWth - which falls in the middle of the range of ABR plant sizes being considered (250 MWth to 2000 MWth). At the time the project was cancelled, the CRBRP had progressed to the point of having completed the licensing application to the Nuclear Regulatory Commission (NRC) and was in the process of receiving NRC approval. Therefore, it was felt that [CRBRP, 1977] provides some of the best available data and information as input to the GNEP PEIS work. CRBRP was not the source of all the information in this document. It is also expected that the CRBRP data will be bounding from the standpoint of commodity usage because fast reactor vendors will develop designs which will focus on commodity and footprint reduction to reduce the overall cost per kilowatt electric compared with the CRBR plant. Other sources used for this datacall information package are explained throughout this document and in Appendix A. In particular, see Table A.1 for a summary of the data sources used to generate the datacall information.

Again, all of the data gathered for environmental analysis in this EIS reflects what was available from open literature sources including that available on international fast 
reactor designs. Data on current or future international designs was either not available or not of sufficient detail for use in this datacall and EIS. It is expected that along with U.S.-based companies, foreign countries will also propose ABR designs as part of DOE's ABR solicitation, however, those design concepts are not currently available for use as part of this datacall information package. Lastly, similar to what is anticipated for advanced U.S. designs, foreign fast reactor designs, if designed to be safe and economical, will fall within the data envelope of the information contained in this datacall package.

The remaining report sections provide a summary of the safety design approach applicable to an ABR (Sec. 2), a discussion of applicable ABR operations and requirements (Sec. 3), and a summary of the various wastes and emissions generated during plant construction and operation (Sec. 4). Details regarding the data presented in tables in the body of the report are provided in Appendices A, B, and C.

2. ABR Safety Design Approach

\subsection{Sodium Coolant}

When a fission reaction occurs in nuclear reactor fuel, high-energy neutrons traveling at high speed are released in the reaction. In light water reactors, the fuel is of a type that fissions mostly when it absorbs neutrons which are moving relatively slowly, and so it is necessary to slow down the neutrons through collisions with the coolant water. The water thus serves two purposes: removing heat from the reactor core and slowing down neutrons to allow for further fission reactions.

In fast reactors, the fuel is of a type such that most of the fissions are caused by fastmoving neutrons, and so a coolant must be used which does not slow neutrons to the extent that water does. The coolant used in most fast reactors is liquid sodium because it slows fission neutrons much less than does water and it has many desirable thermal and physical properties, such as excellent heat transfer and compatibility with the metals used for reactor fuel cladding, duct walls, etc.

\subsection{Defense in Depth}

The fundamental safety goals in nuclear power reactor design and operation are to assure the health and safety of the public, to protect the plant operating staff from harm, and to prevent plant damage. Traditionally, these goals have been fulfilled by an approach that 1) minimizes risk by maximizing safety margins in design and operation, 2) reduces the likelihood of potentially harmful events by providing safety systems to deal with foreseen events, and 3) provides additional design features to mitigate the harmful consequences of low probability events. This approach is usually identified as "defense in depth."

The basic principle of defense in depth is to provide multiple levels of protection against release of radioactive material. One part of defense in depth is physical barriers, like the multiple barriers to release of radioactivity provided by the fuel cladding, the primary coolant system boundary, and the reactor containment building. Safety systems are 
provided to protect the physical barriers and prevent event sequences from proceeding. Emergency planning provides an additional layer of defense in depth, should the other barriers be threatened. In all instances, the defense-in-depth strategy depends on the independence of the protective measures, so that no single event can breech more than one protective level.

\subsection{Inherent and Passive Safety}

In the current fleet of operating light water reactors (LWRs), the safety systems generally include the reactor shutdown systems, emergency core cooling systems and decay heat removal systems. The safety systems are generally active, depending on electrical or steam power; correct valve alignment; proper performance of pumps, valves and other equipment; and proper operator action. While these systems have proven to be effective when called upon, they are complex and have high capital and maintenance costs.

Most of the modern advanced LWR designs have reduced the dependence on active safety systems in favor of a greater reliance on passive systems that depend on natural phenomena, such as gravity or natural convection flow in cooling systems. Inherent characteristics of the design, such as negative reactivity feedback and long flow coastdown, may provide an additional level of protection.

A sodium-cooled fast reactor provides a demonstrated high level of inherent and passive safety. The coolant thermo-physical properties provide superior heat removal and transport characteristics at low operating pressure with a large temperature margin to boiling. Since the system operates at low pressure, the likelihood of a loss-of-coolant accident is greatly reduced. The reactor guard vessel is designed to hold primary coolant in the event of a leak in the primary coolant system. The reactor guard vessel assures that the reactor core remains covered with sodium and cooled by the emergency heat removal system, even if the primary reactor vessel fails. If primary coolant leaks and oxidizes in the reactor building air atmosphere, or if failures of the cladding and the primary system barriers lead to release of gaseous fission products, the reactor containment building provides a final low-leakage barrier to release of radioactivity to the environment.

The normal process of safety assessment of a design considers a spectrum of design basis accidents (DBAs) as tests of the various safety systems. These DBAs generally assume single failures. Accidents within the design basis must be accommodated by the design and shown to present risks to the public that are within regulatory standards. Beyond the design basis, there exists a class of accidents of such low probability (typically, less than $10^{-6}$ per reactor year, although regulators have not yet assigned a specific probability value) that they have been termed "hypothetical." These events involve multiple failures of safety grade systems. Because of the potentially severe consequences of accidents in this class, they have received significant regulatory scrutiny in prior sodium-cooled fast reactor licensing reviews for the purpose of characterizing thermal and structural safety margins beyond the design basis.

Three beyond-design-basis accident (BDBA) sequences, each involving failure of both reactor scram systems, have received attention in past licensing safety assessments. In 
the unprotected loss-of-flow (ULOF) sequence, it is assumed that power is lost to all primary and secondary coolant pumps, and the reactor scram systems fail to activate. In the unprotected transient overpower (UTOP) sequence, it is assumed that one or more inserted control rods are withdrawn, plus the reactor scram systems fail to operate. In the unprotected loss-of-heat-sink (LOHS) accident, it is assumed that heat removal through the power conversion system is lost, and the reactor scram systems do not activate. Taken collectively, these three accident initiators encompass all the ways that an operating reactor can be perturbed, i.e. by a change in coolant flow, by a change in reactivity, or by a change in coolant inlet temperature.

A sodium-cooled fast reactor can be capable of accommodating these beyond-designbasis accident initiators without producing high temperatures and conditions that might lead to a severe accident, such as coolant boiling, cladding failures, or fuel melting. The inherent neutronic, hydraulic, and thermal performance characteristics of such a reactor provide self-protection in beyond-design-basis sequences to limit accident consequences without activation of engineered systems or operator actions. This characteristic has been termed 'inherent passive safety.'

The efficacy of such passive safety was demonstrated through two landmark tests conducted on the Experimental Breeder Reactor-II (EBR-II), namely loss-of-flow without scram and loss-of-heat-sink without scram tests. With the automated safety systems disabled, the two most demanding accident initiating events were deliberately induced with the reactor at full power, first one, then the other. Each time the reactor simply coasted to a safe, low power state without any damage at all to the fuel or any reactor component. These tests proved conclusively that passive safety design is achievable for metallic-fueled fast reactors with sodium cooling. Additional analyses have shown that inherent reactivity feedback and heat removal performance can be achieved in sodiumcooled, pool-type, metal fueled reactors of all sizes (see [Cahalan, 1990] and [Royl, 1990]).

Within the overall safety framework for ABR, passive safety will serve to provide additional margins for public protection in the event of very low probability events for which the frequency of occurrence is lower than the normal threshold for deterministic assessment. No abnormal radioactivity releases will occur in the event of beyond-designbasis accidents, and all of the multiple defense-in-depth barriers (fuel cladding, reactor vessel, containment building) for public protection will remain intact, just as for designbasis accidents. The passive safety performance of ABR will eliminate the potential for severe accident consequences in very low frequency, beyond-design-basis sequences. Consequently, for ABR, beyond-design-basis accidents need to be considered only in the context of probabilistic risk assessments, in which such events are analyzed with bestestimate scoping methods that demonstrate safety margins beyond the normal design basis without requiring the use of deterministic analyses. 


\subsection{Sodium-Cooled Reactor Operating Experience}

Safe, stable and predictable operation of sodium-cooled fast reactors has been demonstrated in many countries worldwide, resulting in a comprehensive understanding of the necessary safety requirements, design features, and operating practices for these reactors. The concept of the sodium-cooled fast reactor has been proven by operational experience in the U.S., U.K., France, Germany, Russia, and Japan. In the U.S., the EBRII and the FFTF operated safely and reliably for 40 reactor-years. While there have been incidents in sodium-cooled fast reactors, including at the Fermi-1 reactor in Michigan (a coolant flow blockage caused by a loose part leading to local fuel melting) and the MONJU reactor in Japan (a leak of non-radioactive sodium due to a piping design deficiency), in no case has there been any uncontrolled release of radioactive material, nor has there been any incident that resulted from a fundamental flaw in the concept of the sodium-cooled fast reactor.

The international community continues to develop fast reactor technology. The BN-800 power plant is under construction at Beloyarsk in Russia. China is constructing a small prototype power reactor near Beijing. India is constructing a large prototype power reactor at Kalpakkam. Construction of new, large sodium-cooled fast reactor plants has been proposed in Russia, France, Japan and the U.S.

\subsection{Inherent Passive Safety in the ABR}

The Advanced Burner Reactor safety design approach will implement the defense-indepth strategy by adopting the traditional three levels of safety. Since the ABR will be a sodium-cooled fast reactor, it will provide significant safety margin enhancements by inherent characteristics that enable passive safety responses to potential accident initiators.

At the first level of safety, the ABR will be designed to operate with a high degree of reliability, so that accident initiators are prevented from occurring. The first level of safety will be assured in part by selection of fuel, cladding, coolant, and structural materials that are stable and compatible and provide large margins between normal operating conditions and limiting failure conditions. Next, the first level of safety will be assured by adopting an arrangement of components that allows monitoring, inspection, and testing for performance changes or degradation and for repair and replacement of components necessary to assure that safety margins are not degraded.

At the second level of safety, the ABR will provide protection in the event of equipment failure or operating error. This level of protection is provided by engineered safety systems for reactor shutdown, reactor heat removal, and emergency power. Each of these safety-grade back-up systems functions in the event of failure in the corresponding operating system and are subjected to continuous monitoring and periodic testing and inspection. 
The ABR will incorporate an independently powered and instrumented secondary reactor shutdown system that operates automatically to reduce reactor power rapidly in the event that the primary shutdown system fails. For shutdown cooling, the ABR will include a safety-grade emergency heat removal system, independent from the normal heat removal system and capable of passively removing residual decay heat by natural circulation. In addition to the normal off-site power supply, the ABR will be equipped with a second, independent safety-grade on-site emergency power supply.

The third level of safety provides additional protection of the public health and safety in an extremely unlikely event that is not expected to occur in the life of the plant, or which was not foreseen at the time the plant was designed and constructed. As an example, level 3 protections for cooling assurance and containment of radioactivity are provided by the reactor guard vessel and the reactor containment building. The reactor guard vessel assures that the reactor core remains covered with sodium and cooled by the emergency heat removal system, even if the primary reactor vessel fails. Similarly, the reactor containment building provides a final low-leakage barrier to release of radioactivity to the environment in the event of a primary coolant leak or of failures of the cladding and the primary system barriers leading to release of gaseous fission products.

\section{ABR Operations and Requirements}

As described in Sec. 1, construction and operating requirements for the Advanced Burner Reactor have been derived largely from CRBRP evaluations discussed in documents available to the public. A more recent preconceptual design of a sodium-cooled fast reactor [Chang, 2006] has been identified for use in describing major plant systems. However, the description presented here is not intended to constrain future design decisions for the ABR. Where design decisions are expected to have a significant influence on environmental impact, conservative choices are made or, as in the case of fuel choice, two alternatives are presented.

The major systems of the ABR are expected to include: 1) the reactor vessel containing the reactor core and the primary sodium coolant, 2) the intermediate heat transport system, which transfers heat from the primary coolant to the secondary coolant, and 3) a power conversion system that uses heat from the secondary coolant to produce electricity. These systems are illustrated in Fig. 1. In this concept, the reactor vessel and primary and secondary heat transport systems are located below grade on a nuclear island which is seismically isolated from its foundations.

Primary system components for the ABR may be arranged in either a pool or loop configuration. Figure 2 illustrates a pool configuration, where the reactor core, primary pumps, intermediate heat exchangers (IHX), and direct reactor auxiliary cooling system heat exchangers (DRACS - not shown in Fig. 2) are contained in a pool of sodium coolant within the reactor vessel. In a pool configuration, all primary sodium coolant piping is within the sodium pool, which virtually eliminates the possibility of a loss of coolant and provides a large thermal inertia during reactor transients. In addition, the reactor vessel is a simple structure with no penetrations, surrounded by an additional 
guard vessel. In a loop configuration, primary pumps and intermediate heat exchangers are external to the reactor vessel and are interconnected by pipes. This type of configuration is illustrated in Fig. 3, which shows a diagram of one of the Fast Flux Test Facility (FFTF) loops.

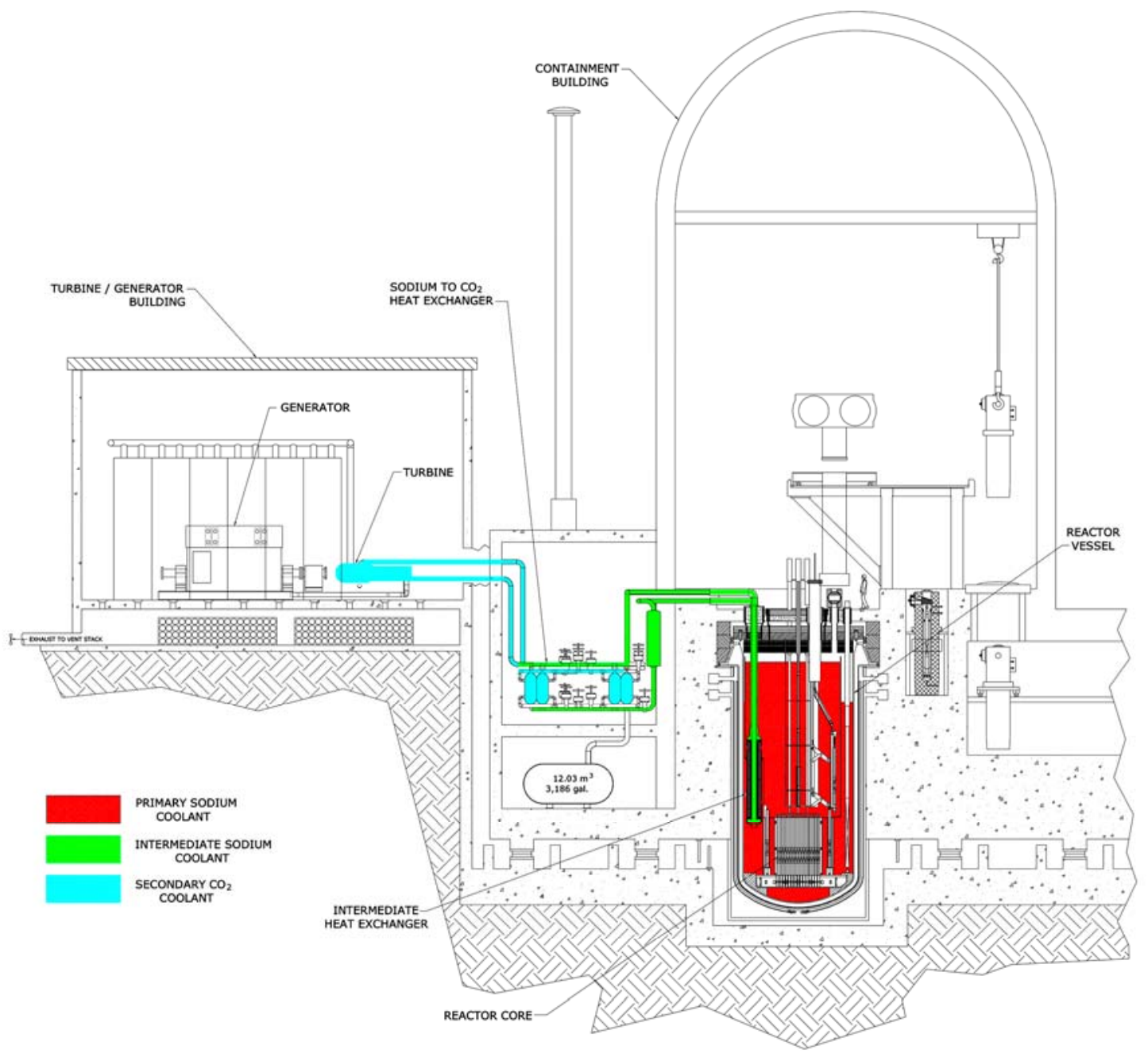

Figure 1. Elevation view shows the reactor vessel and containment secondary heat transport system and power conversion system.

The fundamental flow path for sodium is similar between pool and loop configurations. Primary pumps discharge sodium coolant into the inlet plenum of the core. The coolant is heated as it flows through the core and then exits into the outlet plenum. Heated sodium then flows through the IHXs, where it gives up its heat to the intermediate heat transport system and then returns to be drawn back into the primary pumps.

The relationship among the primary, intermediate, and secondary heat transport systems is shown in Fig. 1, where a supercritical $\mathrm{CO}_{2}$ Brayton cycle is assumed for the power conversion system, although a steam Rankine cycle can also be used. In the intermediate 


\section{Argonne}

ANL-AFCI-183, Rev. 0.5 Preliminary NEPA Data Study

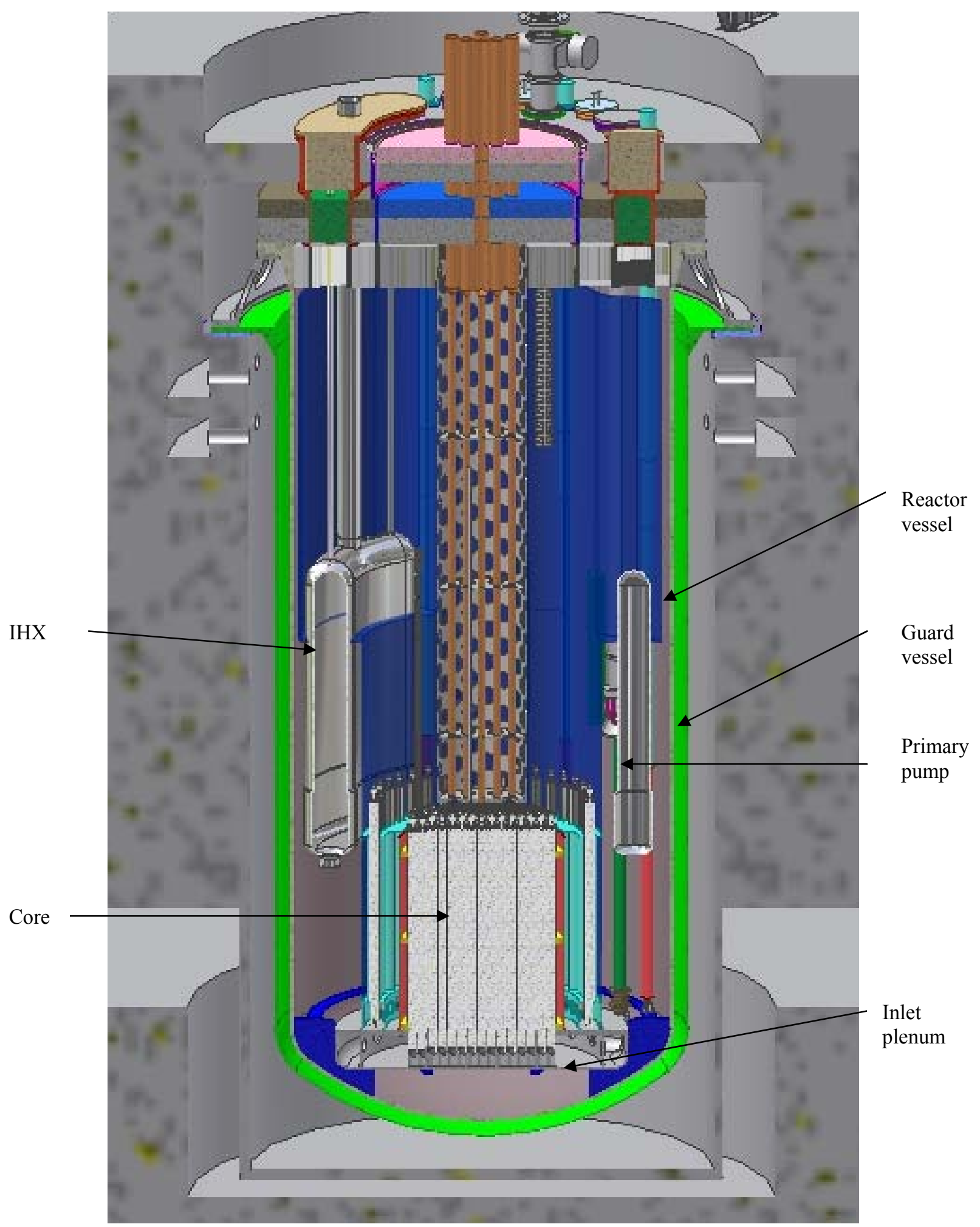

Figure 2. Cut-away view of a pool configuration shows the primary heat transport system within the reactor vessel. [Chang, 2006] 


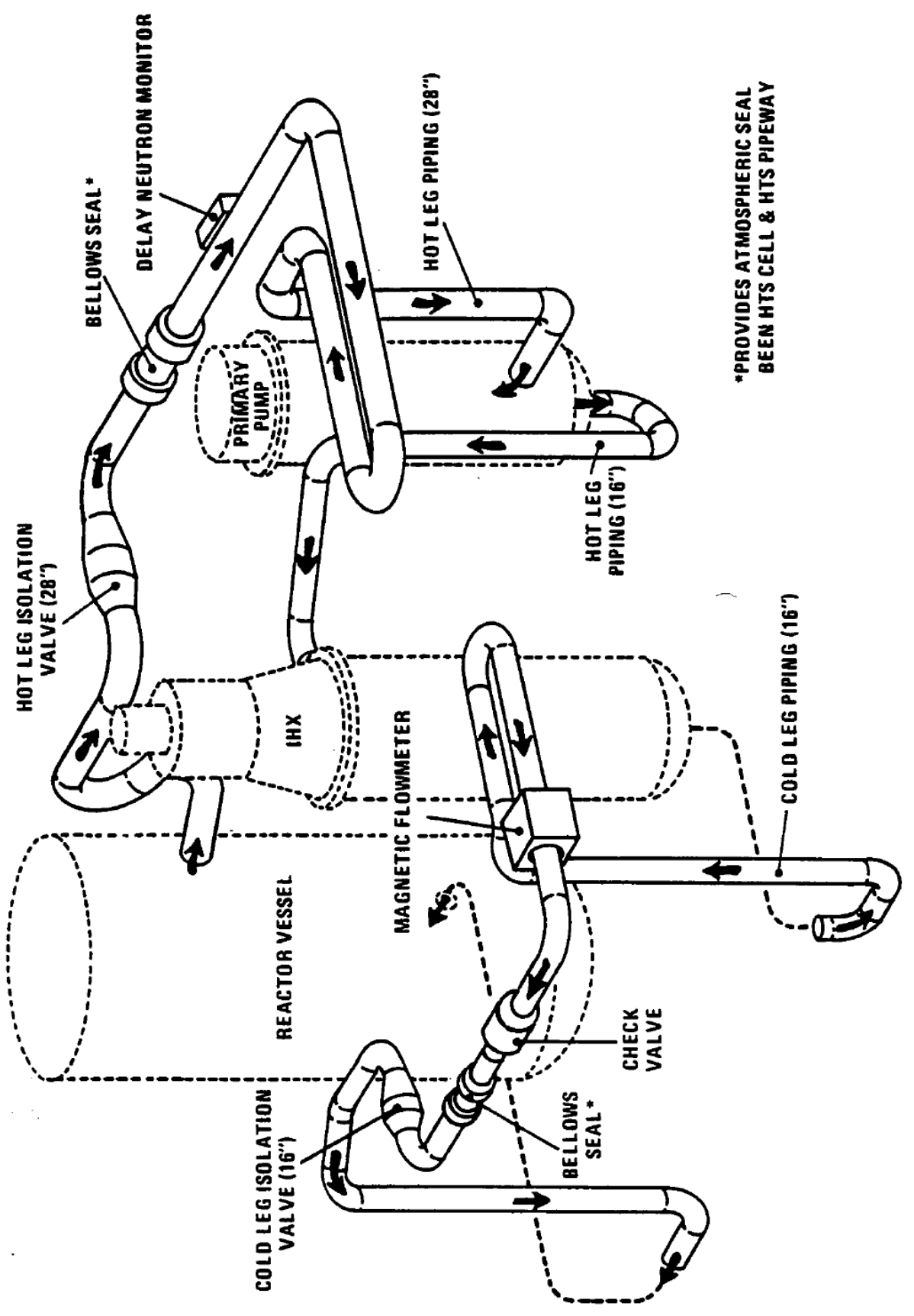

Figure 3. Diagram of the FFTF loop configuration, showing one of the loops [Cabell, 1980] 
heat transport system, pumps circulate sodium coolant through the IHXs to recover heat from the primary system. The coolant then flows through steam generators (for the Rankine cycle option) or sodium-to- $\mathrm{CO}_{2}$ heat exchangers (for the advanced supercritical $\mathrm{CO}_{2}$ Brayton cycle option) to transfer heat to the power conversion system. The power conversion system uses the thermal energy to do mechanical work on a turbine-generator and produce electricity. A schematic of a supercritical $\mathrm{CO}_{2}$ Brayton cycle power conversion system concept is presented in Fig. 4, and a schematic of a steam cycle system is diagrammed in Fig. 5.

\subsection{Fissile Material Inventory}

The power level of the ABR core has not yet been finalized but is evaluated in the range between $250 \mathrm{MWth}$ and $2000 \mathrm{MWth}$. A $250 \mathrm{MWth}$ design would, because of its size, be economical to build, yet would be large enough to serve as a small engineering scale demonstration plant. A $2000 \mathrm{MWth}$ plant, on the other hand, would provide a full-scale commercial demonstration of the ABR concept, at a higher cost. It is expected that the final ABR design will fall in between these two values. Therefore, parameters which are a function of reactor power level have been estimated in this report for a $250 \mathrm{MWth}$ core, a $1000 \mathrm{MWth}$ core, and a $2000 \mathrm{MW}$ th core, thus providing both mid-range and bounding values for these parameters. See Appendix A, Table A.2, for a summary of the methods used to scale various parameters for reactor power.

Startup fuel type has also not been finalized but will be either metal (U-Pu-Zr or U-Zr) or mixed oxide $\left(\mathrm{UO}_{2}-\mathrm{PuO}_{2}\right)$. Therefore, fuel cycle analysis results are presented for both metal and oxide candidate core designs.

Table 1 lists fissile material inventory in the reactor core at all three power levels and for both types of cores. The table also gives estimates of the maximum fissile inventory (fresh plus spent fuel) on site over sixty years of operation, assuming that the ABR is not co-located with a startup fuel reprocessing facility and that the startup fuel is stored on site indefinitely. See the discussion of Table 1 in Appendix A for details of the data calculations.

\subsection{Fuel Handling}

Fuel assemblies for the ABR will be delivered from one of two sources: either from a colocated fuel processing and fabrication facility [Chang, 2006] or from offsite fabrication facilities in DOE/DOT-approved shipping containers. In either case, new fuel assemblies enter the primary containment building through an intra-building transfer area. Major components in the fuel handling system are indicated in Fig. 6, which shows an artist's rendition of a candidate ABR concept. The intra-building tunnel will interface with a fuel staging/storage area that is either part of the ABR facility or part of a co-located fuel processing facility. 


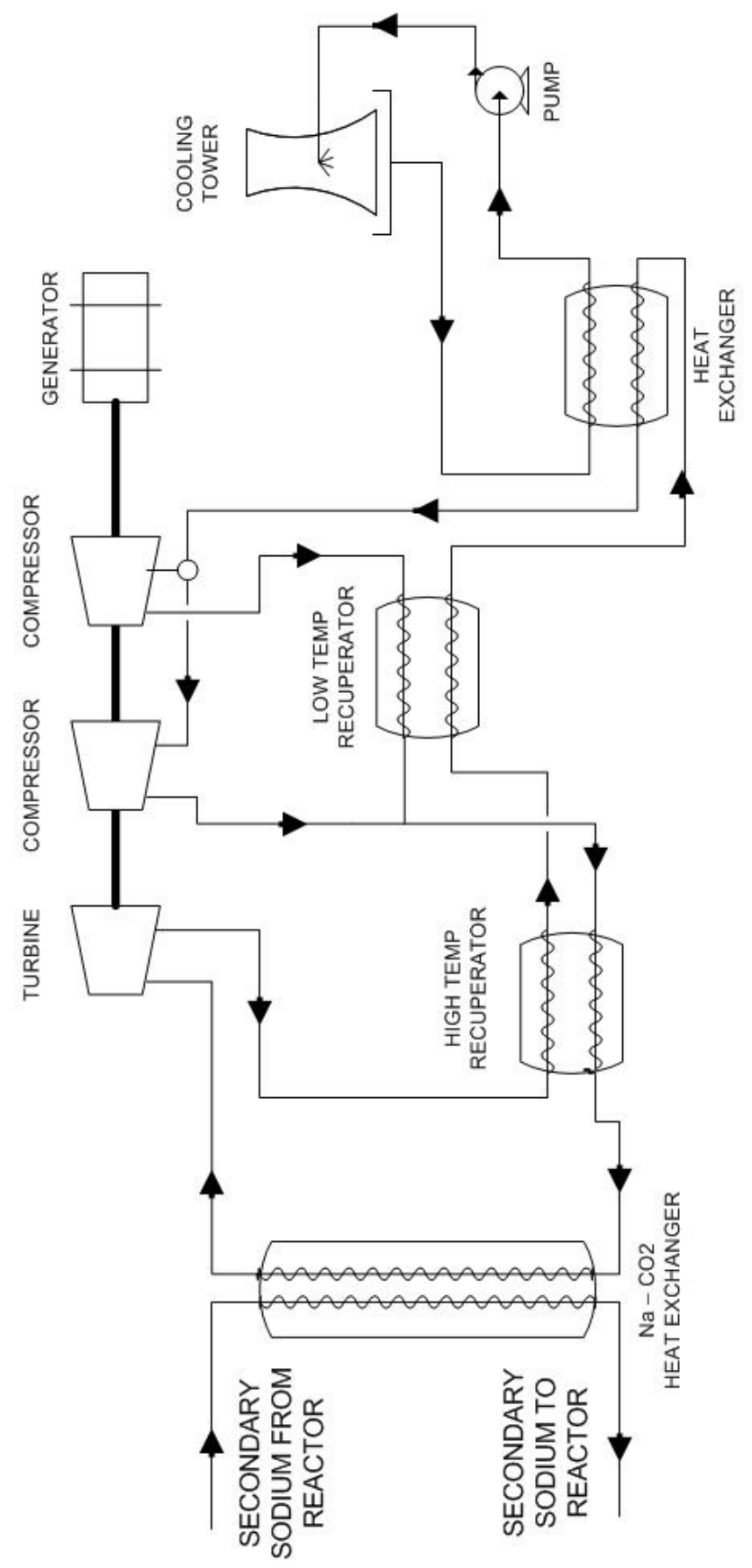

Figure 4. Candidate $\mathrm{ABR}$ supercritical $\mathrm{CO}_{2}$ Brayton cycle power conversion system 


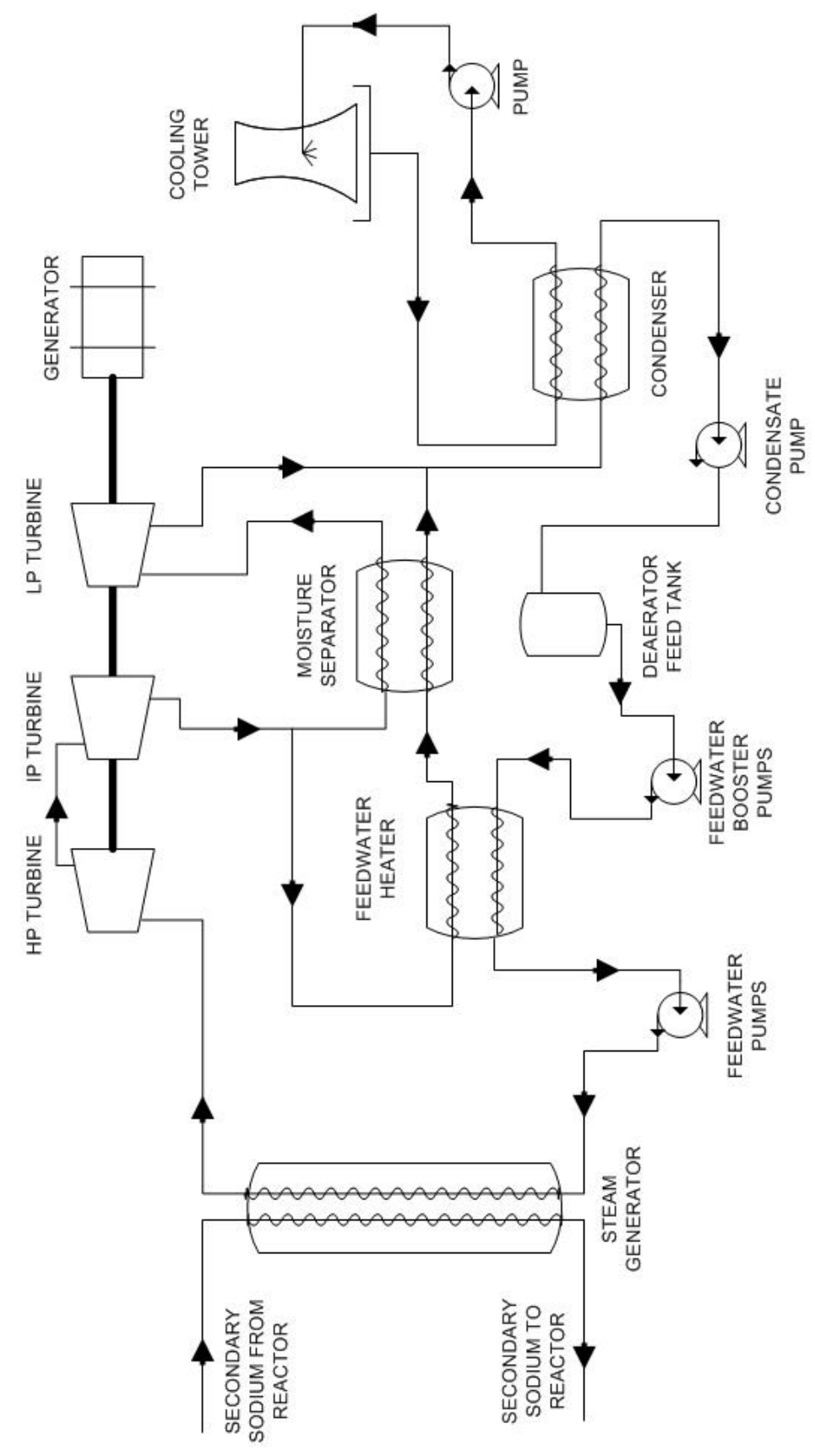

Figure 5. Candidate ABR Steam Cycle Power Conversion System 


\begin{tabular}{|l|c|c|}
\hline \multicolumn{3}{|c|}{ Table 1. ABR Fissile Inventory } \\
\hline & Metal (kg.) & Oxide $^{*}$ (kg.) \\
\hline 250 MWth, core + in-vessel storage & 550 & 580 \\
\hline 1000 MWth, core + in-vessel storage & 2260 & 2550 \\
\hline 2000 MWth, core + in-vessel storage & 4,600 & 4,770 \\
\hline 250 MWth, maximum on site & 12,500 & 13,200 \\
\hline 1000 MWth, maximum on site & 25,700 & 24,200 \\
\hline 2000 MWth, maximum on site & 60,600 & 63,400 \\
\hline
\end{tabular}

Core adjusted to the same TRU conversion ratio as the metal core

Once fuel enters the containment building, it is transferred to the fuel unloading machine for placement into the reactor vessel. An in-vessel fuel handling machine manages the movement and placement of fuel within the reactor vessel. Spent fuel that is removed from the reactor vessel by the fuel unloading machine is placed into an intra-building cask and returned to the fuel staging/storage area.

\subsection{Facility Requirements}

\subsubsection{Industrial Security and Safeguards}

The industrial security and safeguards system [Chang, 2006] is designed to protect plant equipment and personnel and to prevent the theft of special nuclear materials. The system is designed to defend against the design basis threats specified in regulations. The key requirements for the security and safeguards systems are:

- Allow plant access only to authorized personnel and material

- Prevent the theft of special nuclear materials

- Prevent the sabotage of critical plant equipment

- Deter, detect, and delay unauthorized activities and assaults on the plant

\subsubsection{Buildings and Structures}

In addition to buildings and structures to house the primary and secondary heat transport systems and the power conversion system, a number of other buildings necessary to support overall operations are part of the ABR facility. As discussed in [Chang, 2006], these include a control/personnel building as well as buildings for radwaste and maintenance, balance-of-plant services, emergency generators, and security. A site plan for the 2000 MWth design is shown in Fig. 7. A list of site buildings and structures for the ABR concept, including currently proposed dimensions, is given in Table 2 for a 250 MWth ABR design, a 1000 MWth design, and a 2000 MWth design. It should be noted that the ABR facility design will continue to evolve, and as it evolves, designs of 
particular buildings and structures may change. Therefore, dimensions and site layout of later designs may differ from those given in Table 2 and in Fig. 7.

\subsubsection{Reactor Building}

The reactor building encloses the entire primary reactor system and secondary heat transport system and is constructed on a seismically-isolated basemat structure. The building is a reinforced-concrete containment structure that contains an inner reactor containment dome and is designed for a maximum leak rate of $0.1 \%$ day at an internal

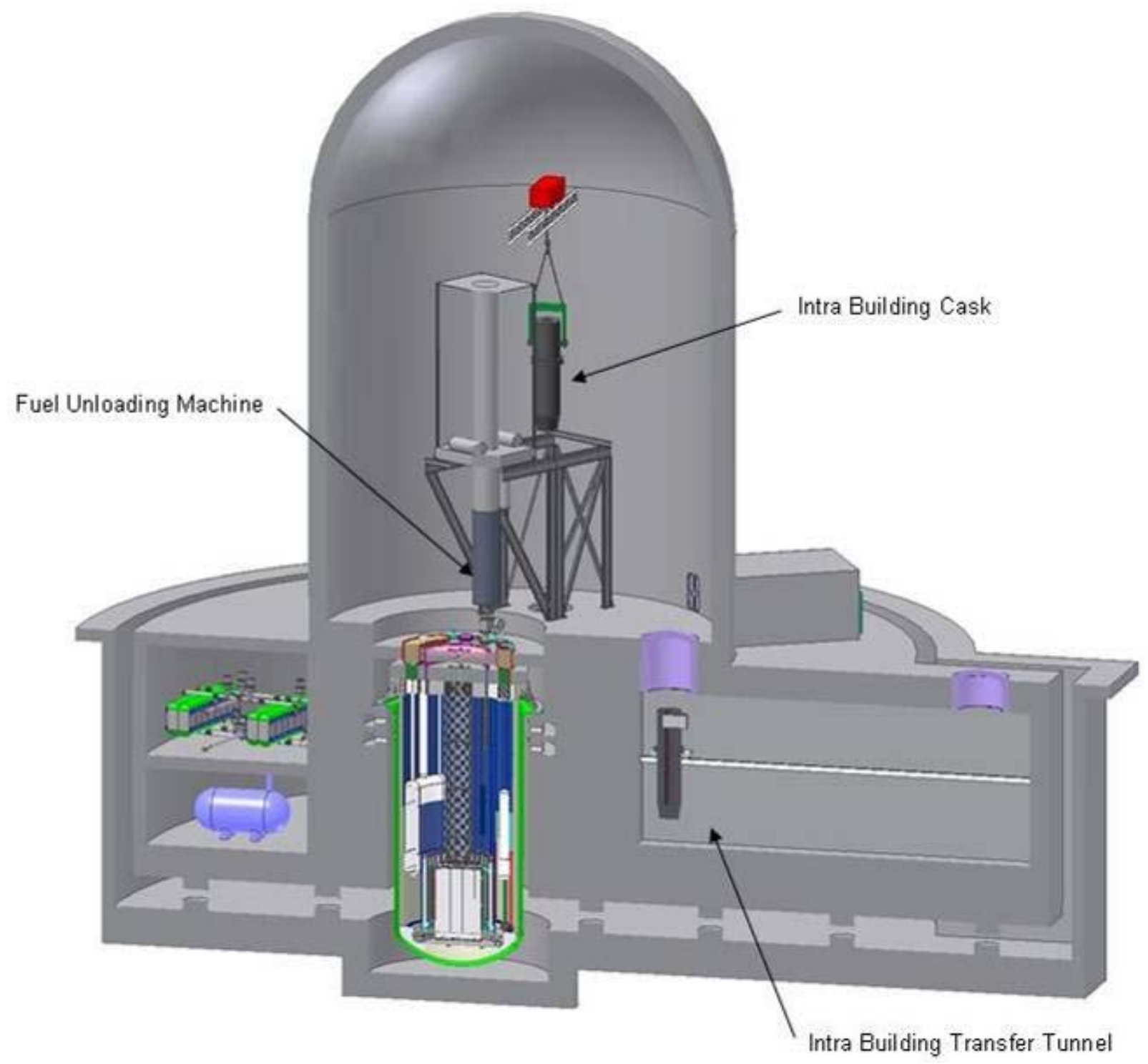

Figure 6: Major components of the fuel handling system in a candidate ABR concept.

[Chang, 2006] 


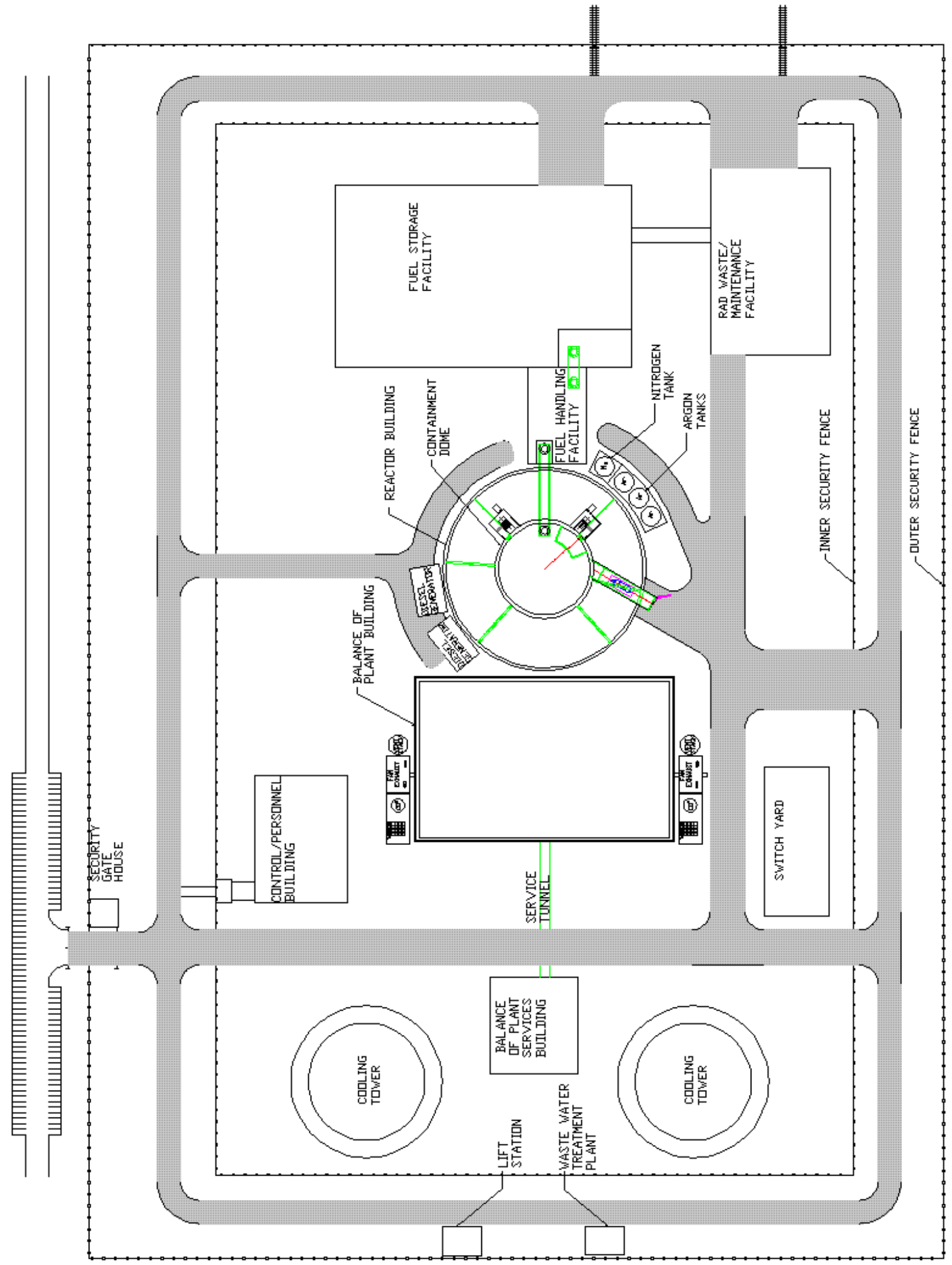

Figure 7. Site plan for the ABR. 


\begin{tabular}{|c|c|c|c|c|c|c|c|c|c|c|c|c|}
\hline \multirow[b]{2}{*}{ Building Name } & \multicolumn{3}{|c|}{ Footprint $\left(\mathrm{ft}^{2}\right)$} & \multicolumn{3}{|c|}{ Length (ft) } & \multicolumn{3}{|c|}{ Width (ft) } & \multicolumn{3}{|c|}{ Height (ft) } \\
\hline & $\begin{array}{c}250 \\
\text { MWth }\end{array}$ & $\begin{array}{l}1000 \\
\text { MWth }\end{array}$ & $\begin{array}{l}2000 \\
\text { MWth }\end{array}$ & $\begin{array}{c}250 \\
\text { MWth }\end{array}$ & $\begin{array}{c}1000 \\
\text { MWth }\end{array}$ & $\begin{array}{l}2000 \\
\text { MWth }\end{array}$ & $\begin{array}{c}250 \\
\text { MWth }\end{array}$ & $\begin{array}{l}1000 \\
\text { MWth }\end{array}$ & $\begin{array}{l}2000 \\
\text { MWth }\end{array}$ & $\begin{array}{c}250 \\
\text { MWth }\end{array}$ & $\begin{array}{c}1000 \\
\text { MWth }\end{array}$ & $\begin{array}{c}2000 \\
\text { MWth }\end{array}$ \\
\hline Reactor Building & 7,832 & 32,685 & 32,685 & 89 dia. & 204 dia & 204 dia. & - & - & - & 100 & 140 & 140 \\
\hline BOP Building & 3,336 & 41,860 & 41,860 & 72 & 260 & 260 & 46 & 161 & 161 & 49 & 75 & 75 \\
\hline $\begin{array}{l}\text { Control/ } \\
\text { Personnel Building }\end{array}$ & 6,319 & 12,600 & 12,600 & 89 & 131 & 131 & 71 & 96 & 96 & 30 & 30 & 30 \\
\hline $\begin{array}{l}\text { Radwaste/ } \\
\text { Maintenance Facility }\end{array}$ & 6,000 & 24,000 & 24,000 & 100 & 124 & 124 & 60 & 193 & 193 & $40 / 80^{*}$ & $40 / 80^{*}$ & $40 / 80^{*}$ \\
\hline Security Gate House & 900 & 900 & 900 & 30 & 30 & 30 & 30 & 30 & 30 & 16 & 16 & 16 \\
\hline $\begin{array}{l}\text { Emergency Gen. Bldg. } \\
\text { ( } 2 \text { for } 1000 \text { and } 2000 \\
\text { MWth ABR) }\end{array}$ & 375 & $\begin{array}{l}1,500 \\
\text { each }\end{array}$ & $\begin{array}{l}1,500 \\
\text { each }\end{array}$ & 25 & $\begin{array}{c}50 \\
\text { each }\end{array}$ & $\begin{array}{c}50 \\
\text { each }\end{array}$ & 15 & $\begin{array}{c}30 \\
\text { each }\end{array}$ & $\begin{array}{c}30 \\
\text { each }\end{array}$ & 12 & 12 each & 12 each \\
\hline BOP Services Building & 2,250 & 9,000 & 9,000 & 50 & 100 & 100 & 45 & 90 & 90 & 20 & 20 & 20 \\
\hline Lift Station & 1,200 & 1,200 & 1,200 & 40 & 40 & 40 & 30 & 30 & 30 & 16 & 16 & 16 \\
\hline $\begin{array}{l}\text { Wastewater Treatment } \\
\text { Plant }\end{array}$ & 1,200 & 4,800 & 9350 & 40 & 80 & 110 & 30 & 60 & 85 & 16 & 16 & 16 \\
\hline Fuel Handling Facility & 6,000 & 6,000 & 6,000 & 100 & 100 & 100 & 60 & 60 & 60 & 16 & 16 & 16 \\
\hline Fuel Storage Facility & 31,250 & 57,400 & 57,400 & 250 & 307 & 307 & 125 & 187 & 187 & 16 & 16 & 16 \\
\hline Cooling Towers (each) ${ }^{* *}$ & 2,352 & 19,300 & 19,300 & 48 & 156 dia. & 156 dia. & 48 & - & - & 33 & 220 & 220 \\
\hline $\begin{array}{l}\text { Interior Security } \\
\text { Perimeter Fence }\end{array}$ & $1.1 \times 10^{5}$ & $7.1 \times 10^{5}$ & $7.1 \times 10^{5}$ & 435 & 1,085 & 1,085 & 244 & 660 & 660 & - & - & - \\
\hline $\begin{array}{l}\text { Exterior Security } \\
\text { Perimeter Fence }\end{array}$ & $2.4 \times 10^{5}$ & $1.1 \times 10^{6}$ & $1.1 \times 10^{6}$ & 616 & 1,253 & 1,253 & 394 & 885 & 885 & - & - & - \\
\hline
\end{tabular}

* $80 \mathrm{ft}$. high bay for maintaining tall components, $40 \mathrm{ft}$. low bay for other maintenance, waste management, etc.

${ }^{* *}$ Dimensions in Table 2 are for wet cooling towers. 
pressure of 10 psig. The reactor building is a conventional reactor containment structure with the reactor vessel assembly located below grade. All of the primary radioactive systems are located below grade within the reactor building.

\subsubsection{Balance of Plant Building}

The balance of plant building contains the power conversion systems, which will be based on either a steam Rankine cycle or a super-critical $\mathrm{CO}_{2}$ Brayton cycle. Future design considerations for the ABR will determine the type of power conversion system to use. Regardless of choice, the ABR will have nearly identical operating conditions for the primary and secondary systems, and overall plant efficiency will be similar.

In the preconceptual design discussed in [Chang, 2006], the balance of plant building houses a supercritical $\mathrm{CO}_{2}$ Brayton cycle and consists of upper and lower levels. The building heating and air conditioning system maintains an ambient temperature for the enclosed equipment and maintains a slightly negative atmospheric pressure relative to the outside so that minor $\mathrm{CO}_{2}$ leaks would be contained within the structure. All ventilation equipment is located adjacent to the building to deliver air for cooling of the generator and ambient temperature control for the building.

The lower level is located below grade. The lower level is open to the upper floor, so that, in the event of a leak, the $\mathrm{CO}_{2}$ will sink and collect in the lower level. The lower level also contains the inventory control tanks and the letdown tanks which are part of the Brayton cycle system on the upper level. Access to this lower level will be for inspection of the tanks or maintenance purposes only.

If a Rankine cycle is used instead for the power conversion system, the Brayton cycle equipment in the balance of plant building will be replaced by the feedwater and condensate systems equipment, such as the deaerator, condenser, feedwater pumps, etc.

\subsubsection{Control Room and Personnel Building}

The reactor control building is a multi-story building adjoining the reactor building. This concrete and steel tornado-hardened, Seismic Category 1 structure houses the control room, technical support center, and the central computers for the overall plant. It also includes space for switchgears; cable routing rooms; motor-generator sets; heating, ventilating, and air conditioning equipment; compressed air; and other auxiliary systems. Fire protection/suppression systems are also provided.

\subsubsection{Radwaste/Maintenance Building}

The radwaste/maintenance building is a slab-on-grade sheet metal high bay structure that provides two areas: a waste management area and a maintenance area. The waste management area is sized and designed to handle the collection, treatment, staging and shipment for disposal of all regulated wastes generated at the site. Waste will be generated from on-going and periodic maintenance work during the life of the plant. 


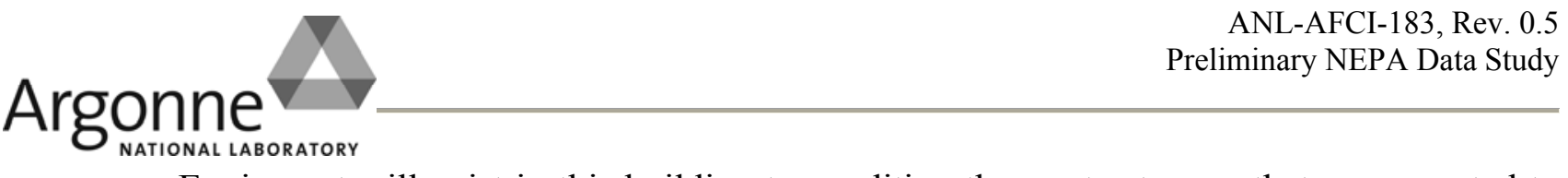

Equipment will exist in this building to condition the waste streams that are expected to be generated from the plant.

The maintenance side of the building provides space and equipment for the routine and planned maintenance of the facility and equipment. The maintenance building also has a location in the structure where large components will be assembled prior to installation in the reactor building. A rail spur provides easy access and delivery of components such as the reactor vessel module, primary pumps, intermediate heat exchangers, and balance-ofplant system equipment to the maintenance area during installation and checkout of the primary and secondary systems. After the facility has been constructed, the maintenance building will then have space and equipment for performing routine and non-routine maintenance of the reactor primary and secondary systems.

\subsubsection{Security Gate House}

The security gate house is a single-story reinforced concrete non-seismic category structure with a reinforced concrete slab located at grade. The windows are made from bullet-proof glass.

The security gate house provides a controlled means of access to the plant site to prevent inadvertent access, industrial sabotage or the theft of nuclear materials. All personnel must pass through this building and be checked by the associated security systems for ingress and egress to sensitive plant structures/areas, or areas where radioactive materials are stored. The plant security system is monitored and operated from this building. A truck trap is located adjacent to this building that allows for security force control and containment of trucks requiring access to the site for deliveries or pickups.

\subsubsection{Emergency Generator Buildings}

Gas or diesel generator buildings are located adjacent to the reactor control building. The $250 \mathrm{MWth}$ plant has one building housing two modular $1 \mathrm{MWe}$ generators that provide emergency power to the primary and secondary systems upon demand. The $1000 \mathrm{MWth}$ plant has two buildings housing one 3 MWe generator each, while the $2000 \mathrm{MWth}$ plant has two buildings housing two 3 MWe generators each. The emergency generator buildings are shipped as single integrated units that can be quickly installed at the site and made operable to support the construction activities during the facility construction, emergency power during reactor operations, and as an alternative source of power during reactor decommissioning.

\subsubsection{Balance of Plant Services Building}

The balance of plant services building provides space for equipment that supports the balance of plant building, cooling towers, and other services. This includes recirculation pumps, water conditioning equipment, air compressors, electrical switchgears, motor control centers, plant heating systems, and other support equipment.

\subsubsection{Lift Station Building and Wastewater Treatment Plant Building}


The lift station building provides pumps and filtration system to pump water from the river (or other suitable cooling water source) to the plant for use in cooling and domestic water services. The lift station footprint should be about the same for all three candidate plants, since pump footprint does not increase much as pump flow increases within the range of the plants, plus, if additional pumps are needed, the pumps can be stacked vertically. All wastewaters go through the wastewater treatment plant, where the water is treated prior to being discharged. Assuming the wastewater treatment function is approximately proportional to the surface area of ponds, tanks, etc. and that the surface area of these components should scale approximately linearly with reactor power, the wastewater treatment plant building footprint should scale approximately linearly with reactor power, as shown in Table 2 . The slight deviation from linear scaling between the $1000 \mathrm{MWth}$ and $2000 \mathrm{MWth}$ footprints comes from having restricted the building length and width to whole numbers which would give approximate linear increases with power in the building area.

\subsubsection{Fuel Handling Facility Building}

The fuel handling facility houses the fuel receiving, storage, and shipping system. It also contains the instrumentation and control system that is used to operate 1) the fuel receiving, storage, and shipping system and 2) the fuel handling system. New core assemblies enter the fuel handling facility and are unloaded from the shipping containers and inspected. They are then temporarily stored in the air cell, from which they are transferred by the inter-building coffin to the reactor building prior to core loading. A spent fuel assembly is removed by the pantograph fuel handling machine from storage around the core barrel and transferred to the fuel unloading machine, which places the assembly in the inter-building coffin and transfers it back to the air cell in the fuel handling facility.

\subsubsection{Fuel Storage Facility Building}

The fuel storage facility provides long-term storage for spent ABR fuel. The building can be used simply for spent fuel storage, or it can house a fuel cycle facility for processing spent fuel. Fuel is transferred from the fuel handling facility to the fuel storage facility via an inter-building coffin.

\subsubsection{Cooling Towers}

Four open-evaporative, forced-air counter flow wet cooling towers are used in the 250 MWth design to reject heat to the atmosphere. Each tower has an induced draft, axial fan at the tower outlet. The 1000 and 2000 MWth plant designs operate with natural draft wet cooling towers (one for the $1000 \mathrm{MWth}$ plant, two for the $2000 \mathrm{MWth}$ plant). Forced convection towers are more cost effective for lower heat loads and so are suitable for the $250 \mathrm{MWth}$ design. The large natural draft towers are more efficient for larger heat loads and are therefore used for the 1000 and 2000 MWth plants. Figure 8 shows an example of forced convection cooling towers similar to those proposed for the $250 \mathrm{MWth} A \mathrm{AR}$ 
plant design. Dry cooling towers could be used with any of the three plants if indicated by local conditions.

\subsubsection{Radioactive and Hazardous Wastes from Operations}

Estimates of annual low-level, mixed low-level, and hazardous wastes in both liquid and solid form are shown in Table 3. Liquid low-level waste is generated from decontaminating radioactive systems and is assumed to scale approximately linearly with reactor power. Solid low-level waste is a mixture of items, some of which do not scale with power. Transuranics will appear only in miniscule amounts in the liquid waste effluent, and so there will be no transuranic waste requiring separate disposal. Hazardous liquid waste comes from the chemical waste treatment system and may include, if a steam Rankine cycle is used in the power conversion system, clarifier blowdown, backwashes, and regenerant wastes and will also include rinse water from the process water treatment systems and non-radioactive building floor drainage. Hazardous solid

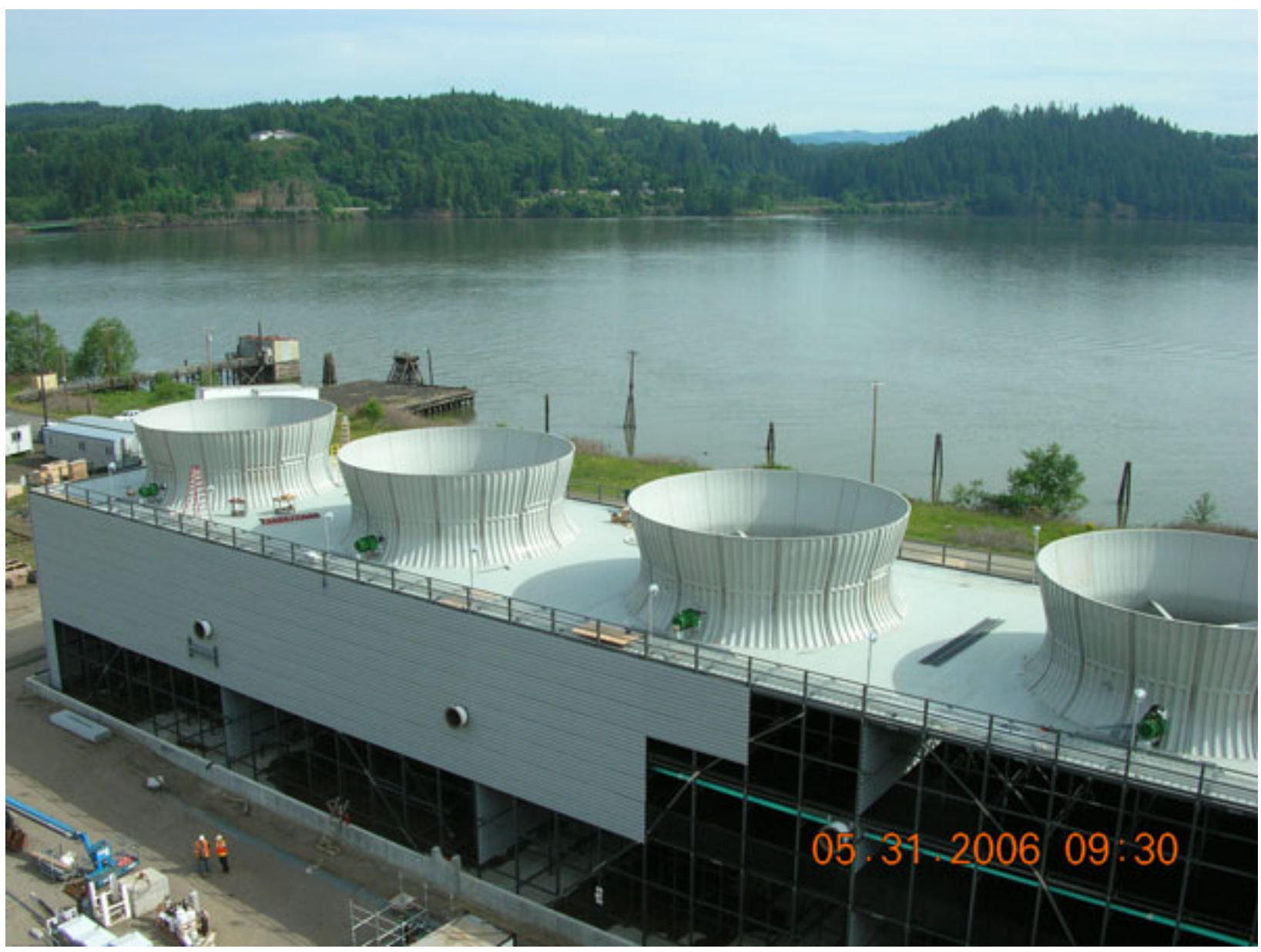

Figure 8. Example of forced convection cooling towers. 
waste is the result of processing solid wastes from the balance of plant system.

The bases for the values given in Table 3 are detailed in the discussion of Table 3 in Appendix A.

\subsubsection{Non-hazardous Operations Wastes}

Table 4 provides data on non-hazardous wastes from plant operations. Sanitary waste is assumed to be processed on site by a sanitary waste system. Water effluent from the waste system will be returned to a local body of water, similar to practices in most municipalities. Sludge from the processing of sanitary waste will be transported off site. See the discussion of Table 4 in Appendix A for details of the data calculations.

All other non-hazardous waste is expected to be ordinary trash, which would be transported off site.

\begin{tabular}{|c|c|c|c|c|c|c|}
\hline \multirow{2}{*}{$\begin{array}{l}\text { ABR Power } \\
\text { Capacity }\end{array}$} & \multicolumn{2}{|c|}{250 MWth } & \multicolumn{2}{|c|}{1000 MWth } & \multicolumn{2}{|c|}{2000 MWth } \\
\hline & Liquid & Solid & Liquid & $\underline{\text { Solid }}$ & Liquid & $\underline{\text { Solid }}$ \\
\hline Low-Level & $7.9 \times 10^{4}$ gal. & $\overline{55 \mathrm{yd}^{3}}$ & $3.2 \times 10^{5}$ gal. & $82 \mathrm{yd}^{3}$ & $6.3 \times 10^{5}$ gal. & $\overline{119 \mathrm{yd}^{3}}$ \\
\hline Mixed Low-Level & negligible & $4.3 \mathrm{yd}^{3}$ & negligible & $11.4 \mathrm{yd}^{3}$ & negligible & 19.6 yd. $^{3}$ \\
\hline Hazardous & $4.6 \times 10^{6}$ gal. & $\begin{array}{c}9.1 \times 10^{4} \mathrm{lb} . \\
\text { max. }\end{array}$ & $1.84 \times 10^{7}$ gal. & $\begin{array}{c}3.65 \times 10^{5} \mathrm{lb} \\
\max .\end{array}$ & $3.7 \times 10^{7}$ gal. & $\begin{array}{c}7.3 \times 10^{5} \mathrm{lb} . \\
\text { max. }\end{array}$ \\
\hline
\end{tabular}

\begin{tabular}{|l|c|c|c|c|c|c|}
\hline \multicolumn{7}{|c|}{ Table 4. Estimated Annual Non-hazardous Operations Wastes } \\
\hline & \multicolumn{2}{|c|}{ 250 MWth } & \multicolumn{2}{c|}{$\mathbf{1 0 0 0}$ MWth } & \multicolumn{2}{c|}{ 2000 MWth } \\
\hline & Liquid (gal.) & Solid $\left(\mathrm{yd}^{3}\right)$ & $\underline{\text { Liquid }(\mathrm{gal} .)}$ & $\underline{\text { Solid }\left(\mathrm{yd}^{3}\right)}$ & $\underline{\text { Liquid }(\mathrm{gal} .)}$ & $\underline{\text { Solid }\left(\mathrm{yd}^{3}\right)}$ \\
\hline Sanitary & $1.9 \times 10^{6}$ & $3.5 \mathrm{yd}^{3}$ & $2.2 \times 10^{6}$ & 4.0 & $2.4 \times 10^{6}$ & 4.5 \\
\hline Other & negligible & 1150 & negligible & 1300 & negligible & 1450 \\
\hline
\end{tabular}

\subsubsection{Annual Operations Data}

Estimates of plant electrical requirements are summarized in Table 5. Appendix A provides details on how these estimates were calculated. The majority of the electrical energy demand is from the motors on the primary and intermediate sodium pumps, the water recirculation pumps, and, if a Brayton cycle is used for power conversion, the $\mathrm{CO}_{2}$ compressors, if the compressors are powered by electric motors (option 2), rather than being driven directly by the turbine (option 1). If a Rankine cycle is used instead, the electrical demand of the power conversion system will come from the feedwater and the condensate pumps [Lomperski, 2007]. 


\begin{tabular}{|c|c|c|c|c|}
\hline \multicolumn{5}{|c|}{ Table 5. ABR Estimated Annual Electrical Requirements } \\
\hline \multirow{19}{*}{$\begin{array}{l}\text { Electrical } \\
\text { Energy }\end{array}$} & \multicolumn{3}{|c|}{ Plant Specifications } & \multirow{2}{*}{$\begin{array}{r}\text { Consumption/Use } \\
5.09 \times 10^{4} \mathrm{MWh}\end{array}$} \\
\hline & \multirow{6}{*}{$\begin{array}{l}250 \\
\text { MWth }\end{array}$} & \multirow{2}{*}{ Brayton option 1} & Centrifugal pumps & \\
\hline & & & Electromagnetic pumps & $6.04 \times 10^{4} \mathrm{MWh}$ \\
\hline & & \multirow{2}{*}{ Rankine } & Centrifugal pumps & $7.20 \times 10^{5} \mathrm{MWh}$ \\
\hline & & & Electromagnetic pumps & $8.15 \times 10^{5} \mathrm{MWh}$ \\
\hline & & \multirow[b]{2}{*}{ Brayton option 2} & Centrifugal pumps & $5.33 \times 10^{5} \mathrm{MWh}$ \\
\hline & & & Electromagnetic pumps & $5.42 \times 10^{5} \mathrm{MWh}$ \\
\hline & \multirow{6}{*}{$\begin{array}{l}1000 \\
\text { MWth }\end{array}$} & \multirow{2}{*}{ Brayton option 1} & Centrifugal pumps & $1.22 \times 10^{5} \mathrm{MWh}$ \\
\hline & & & Electromagnetic pumps & $1.59 \times 10^{5} \mathrm{MWh}$ \\
\hline & & \multirow{2}{*}{ Rankine } & Centrifugal pumps & $2.07 \times 10^{5} \mathrm{MWh}$ \\
\hline & & & Electromagnetic pumps & $2.44 \times 10^{5} \mathrm{MWh}$ \\
\hline & & \multirow{2}{*}{ Brayton option 2} & Centrifugal pumps & $2.05 \times 10^{6} \mathrm{MWh}$ \\
\hline & & & Electromagnetic pumps & $2.45 \times 10^{6} \mathrm{MWh}$ \\
\hline & \multirow{6}{*}{$\begin{array}{l}2000 \\
\text { MWth }\end{array}$} & \multirow{2}{*}{ Brayton option 1} & Centrifugal pumps & $2.17 \times 10^{5} \mathrm{MWh}$ \\
\hline & & & Electromagnetic pumps & $2.93 \times 10^{5} \mathrm{MWh}$ \\
\hline & & \multirow{2}{*}{ Rankine } & Centrifugal pumps & $3.86 \times 10^{5} \mathrm{MWh}$ \\
\hline & & & Electromagnetic pumps & $4.62 \times 10^{5} \mathrm{MWh}$ \\
\hline & & \multirow{2}{*}{ Brayton option 2} & Centrifugal pumps & $4.07 \times 10^{6} \mathrm{MWh}$ \\
\hline & & & Electromagnetic pumps & $4.15 \times 10^{6} \mathrm{MWh}$ \\
\hline \multirow{18}{*}{$\begin{array}{l}\text { Peak } \\
\text { Electrical } \\
\text { Demand }\end{array}$} & \multirow{6}{*}{$\begin{array}{l}250 \\
\text { MWth }\end{array}$} & \multirow{2}{*}{ Brayton option 1} & Centrifugal pumps & $5.8 \mathrm{MWe}$ \\
\hline & & & Electromagnetic pumps & $6.9 \mathrm{MWe}$ \\
\hline & & \multirow{2}{*}{ Rankine } & Centrifugal pumps & $8.2 \mathrm{MWe}$ \\
\hline & & & Electromagnetic pumps & $9.3 \mathrm{MWe}$ \\
\hline & & \multirow{2}{*}{ Brayton option 2} & Centrifugal pumps & $60.8 \mathrm{MWe}$ \\
\hline & & & Electromagnetic pumps & $61.9 \mathrm{MWe}$ \\
\hline & \multirow{6}{*}{$\begin{array}{l}1000 \\
\text { MWth }\end{array}$} & \multirow{2}{*}{ Brayton option 1} & Centrifugal pumps & 13.9 MWe \\
\hline & & & Electromagnetic pumps & $18.2 \mathrm{MWe}$ \\
\hline & & \multirow{2}{*}{ Rankine } & Centrifugal pumps & $23.6 \mathrm{MWe}$ \\
\hline & & & Electromagnetic pumps & $27.9 \mathrm{MWe}$ \\
\hline & & \multirow{2}{*}{ Brayton option 2} & Centrifugal pumps & $234 \mathrm{MWe}$ \\
\hline & & & Electromagnetic pumps & $238 \mathrm{MWe}$ \\
\hline & \multirow{6}{*}{$\begin{array}{l}2000 \\
\text { MWth }\end{array}$} & \multirow{2}{*}{ Brayton option 1} & Centrifugal pumps & $24.8 \mathrm{MWe}$ \\
\hline & & & Electromagnetic pumps & $33.4 \mathrm{MWe}$ \\
\hline & & \multirow{2}{*}{ Rankine } & Centrifugal pumps & $44.1 \mathrm{MWe}$ \\
\hline & & & Electromagnetic pumps & $52.7 \mathrm{MWe}$ \\
\hline & & Bravton o & Centrifugal pumps & $465 \mathrm{MWe}$ \\
\hline & & Dia) & Electromagnetic pumps & $473 \mathrm{MWe}$ \\
\hline
\end{tabular}

Brayton cycle option 2 [Sienicki, 2007] is the bounding case of several possible options for driving the compressors. This case has a 156.4 MW turbine (for the $250 \mathrm{MW}$ th plant) driving a larger size generator than would be the case if the compressors are driven directly by the turbine. Assuming a $1.5 \%$ efficiency loss, the generator output is 154 MWe versus 95.9 MWe for the best estimate single-shaft case (Option 1). The excess plant electrical output essentially goes to energizing the motors that drive the compressors. Thus, while the compressors draw AC power from the grid, the larger generator outputs that power to the grid. The net electrical power leaving the plant is still close to but slightly less than the 95.9 MWe value for the single-shaft case. For the 1000 MWth plant, these power values increase by a factor of four, and for the 2000 MWth plant, they increase by a factor of eight. 
ANL-AFCI-183, Rev. 0.5

Preliminary NEPA Data Study

Other ABR plant annual operational data estimates are presented in Table 6, with a detailed discussion available in Appendix A. Fossil fuel usage is from grounds maintenance, from monthly testing and potential emergency operation of the emergency

\begin{tabular}{|c|c|c|c|}
\hline \multicolumn{4}{|c|}{ Table 6. ABR Estimated Annual Operations Data } \\
\hline \multirow[t]{2}{*}{ Data } & \multicolumn{3}{|c|}{ ABR Power Capacity } \\
\hline & 250 MWth & 1000 MWth & 2000 MWth \\
\hline $\begin{array}{l}\text { Diesel fuel (No. } 2 \text { oil) for backup generator } \\
\text { testing (gal/yr) }\end{array}$ & 200 & 600 & 1200 \\
\hline Diesel fuel for grounds maintenance (gal/yr) & 3350 & 4200 & 5000 \\
\hline Water & See Table 7 & See Table 7 & See Table 7 \\
\hline \multicolumn{4}{|c|}{ Process gases. } \\
\hline Argon & \multicolumn{3}{|c|}{$\begin{array}{l}\text { Used in closed system, expected consumption } \\
\text { less than } 10 \mathrm{scf} / \mathrm{hr} \text {. }\end{array}$} \\
\hline Nitrogen (scf) & 7300 & 29,000 & 58,000 \\
\hline Hydrogen (liquid, $\mathrm{ft}^{3}$ ) & - & $\begin{array}{l}325, \text { total per yr. } \\
70 \text { stored, if } \\
\text { shipped in. } \\
5 \text { stored, if gen- } \\
\text { erated on-site. }\end{array}$ & $\begin{array}{l}650, \text { total per yr. } \\
150 \text { stored, if } \\
\text { shipped in. } \\
10 \text { stored, if gen- } \\
\text { erated on-site. }\end{array}$ \\
\hline Carbon dioxide $-\mathrm{CO}_{2}$ (kg.) - Brayton cycle only & 54,000 & 216,000 & 432,000 \\
\hline \multicolumn{4}{|c|}{ Chemical use } \\
\hline Sodium hypochlorite - $\mathrm{NaOCl}$ (lb/day, max) & 160 & 630 & 1260 \\
\hline Sulfuric acid $-\mathrm{H}_{2} \mathrm{SO}_{4}(\mathrm{lb} /$ day, $\max )$ & 850 & 3400 & 6800 \\
\hline Sodium hydroxide - $\mathrm{NaOH}$ (lb/day max) & 550 & 2200 & 4400 \\
\hline \multicolumn{4}{|c|}{ If a Rankine steam cycle is used: } \\
\hline Steam $-\mathrm{H}_{2} \mathrm{O}$ & \multicolumn{3}{|c|}{$\begin{array}{l}\text { Used in closed loop steam generators, } \\
\text { minimal consumption }\end{array}$} \\
\hline Hydrazine $-\mathrm{N}_{2} \mathrm{H}_{4}$ (gal.) & $\begin{array}{l}550 \text { annually } \\
200 \text { max. stored }\end{array}$ & $\begin{array}{l}2,200 \text { annually } \\
750 \text { max. stored }\end{array}$ & \begin{tabular}{|l|}
4,400 annually \\
1,500 max. stored \\
\end{tabular} \\
\hline Monoethanolamine (gal.) & $\begin{array}{l}1300 \text { annually } \\
200 \text { max. stored }\end{array}$ & $\begin{array}{l}5,100 \text { annually } \\
650 \text { max. stored }\end{array}$ & $\begin{array}{l}10,200 \text { annually } \\
1300 \text { max. stored }\end{array}$ \\
\hline \multicolumn{4}{|l|}{ Operational Employment } \\
\hline Workers on site during normal operations & 110 & 125 & 140 \\
\hline Workers on site during service shutdown & 185 & 210 & 235 \\
\hline Total workers on payroll (all shifts) & 300 & 344 & 385 \\
\hline Total RAD trained workers & 220 & 250 & 280 \\
\hline Average annual dose to workers & \multicolumn{3}{|c|}{ To be provided by Tetra Tech } \\
\hline Maximum worker dose & \multicolumn{3}{|c|}{ To be provided by Tetra Tech } \\
\hline
\end{tabular}


diesel generators, and possibly from a diesel fire pump, if it is determined that one is needed.

In general, the main process gases used are argon and hydrogen, plus $\mathrm{CO}_{2}$ if a Brayton cycle is used, or nitrogen if a Rankine cycle is used [Chang, 2006]. Argon is used as a cover gas in the reactor, the intermediate heat transport system (IHTS), the IHTS cold traps, and for steam plant applications. Argon is also used for inerting the annular space between the reactor vessel and the guard vessel. Data from [Cutforth, 1971] indicate very low loss of argon from the system is expected. Nitrogen gas is used for steam generator water-side purging. For the 1000 and $2000 \mathrm{MWth}$ plant designs, hydrogen gas is used to cool the main generator stator core and rotating field during operation, whereas the 250 MWth generator is small enough to be air-cooled. Two options are considered for providing hydrogen: having hydrogen delivered by an outside supplier and stored for use, or installing a hydrogen generator on-site and generating hydrogen continuously, with a 6-day reserve in storage. Argon, nitrogen, and $\mathrm{CO}_{2}$ are all stored in tanks in liquid form and vaporized for use. Hydrogen is stored as a liquid in the hydrogen system.

If wet cooling towers are used, the makeup water required dwarfs the makeup required for process water treatment, as indicated in Table 7. If dry cooling towers are used, makeup water requirements are very low, but dry cooling towers would be much larger than wet cooling towers. Details of the data calculations are given in the discussion of Table 7 in Appendix A.

\begin{tabular}{|c|c|c|c|c|c|c|c|c|}
\hline \multicolumn{9}{|c|}{ Table 7. Estimated Annual Makeup Water Usage } \\
\hline & & & & & \multicolumn{2}{|c|}{ Total } & \multicolumn{2}{|c|}{$\begin{array}{l}\text { Waste Water } \\
\text { (blowdown plus } \\
\text { process water) }\end{array}$} \\
\hline $\begin{array}{c}\text { ABR } \\
\text { Power } \\
\text { (MWth) }\end{array}$ & $\begin{array}{c}\text { Cooling } \\
\text { Tower } \\
\text { Evaporation } \\
\text { (gal.) }\end{array}$ & $\begin{array}{l}\text { Cooling } \\
\text { Tower } \\
\text { Drift } \\
\text { (gal.) }\end{array}$ & $\begin{array}{l}\text { Cooling } \\
\text { Tower } \\
\text { Blowdown } \\
\text { (gal.) }\end{array}$ & $\begin{array}{l}\text { Max. } \\
\text { Process } \\
\text { Water } \\
\text { (gal.) }\end{array}$ & $\begin{array}{c}\text { Wet } \\
\text { Cooling } \\
\text { (gal.) }\end{array}$ & $\begin{array}{c}\text { Dry } \\
\text { Cooling } \\
\text { (gal.) }\end{array}$ & $\begin{array}{c}\text { Wet } \\
\text { Cooling } \\
\text { (gal.) }\end{array}$ & $\begin{array}{c}\text { Dry } \\
\text { Cooling } \\
\text { (gal.) }\end{array}$ \\
\hline 250 & $5.57 \times 10^{8}$ & $1.47 \times 10^{7}$ & $3.55 \times 10^{8}$ & $1.64 \times 10^{7}$ & $9.43 \times 10^{8}$ & $1.64 \times 10^{7}$ & $3.71 \times 10^{8}$ & $1.64 \times 10^{7}$ \\
\hline 1000 & $2.23 \times 10^{9}$ & $5.78 \times 10^{7}$ & $1.42 \times 10^{9}$ & $6.57 \times 10^{7}$ & $3.77 \times 10^{9}$ & $6.57 \times 10^{7}$ & $1.49 \times 10^{9}$ & $6.57 \times 10^{7}$ \\
\hline 2000 & $4.46 \times 10^{9}$ & $1.16 \times 10^{8}$ & $2.84 \times 10^{9}$ & $1.31 \times 10^{8}$ & $7.55 \times 10^{9}$ & $1.31 \times 10^{8}$ & $2.97 \times 10^{9}$ & $1.31 \times 10^{8}$ \\
\hline
\end{tabular}

Sodium hypochlorite is injected intermittently for bio-fouling control in the cooling tower and groundwater intake, plus minor amounts to the sanitary system discharge. Sulfuric acid is added occasionally to the cooling tower water and the chemical waste treatment system to control high $\mathrm{pH}$. Sodium hydroxide pellets are added intermittently to the chemical waste treatment system. If a Rankine cycle is used, hydrazine is added to the feedwater as an oxygen scavenger, and monoethanolamine is added to control $\mathrm{pH}$. 
4. Summary of Nuclear Materials, Wastes, Effluents, Emissions, and Utilities during Operations and Construction

4.1 High-level Waste/Spent Nuclear Fuel

On average, one-third of the core is replaced each year. Table 8 lists the annual discharge for both fuel types and for the high and low candidate powers. See Appendix A for further details. The cycle length, or time elapsed between stoppages for refueling, is one year for the 1000 and 2000 MWth ABR designs, two months for the $250 \mathrm{MWth}$ ABR. The $250 \mathrm{MWth}$ ABR has a much shorter cycle length because a core this small has only limited room for control rods and so cannot accommodate a large reactivity swing. In the 1000 and 2000 MWth ABR candidate core designs, the cycle length was targeted at one year in order to increase the capacity factor. The longer cycle length results in a large reactivity swing, which can be handled by including a large number of control rods, since the core designs have sufficient space for many control rods.

Spent nuclear startup fuel will be stored on-site for eventual reprocessing

\begin{tabular}{|c|c|c|c|c|}
\hline \multicolumn{5}{|c|}{ Table 8. Annual Spent Fuel Discharge from the ABR } \\
\hline \multirow[b]{2}{*}{$\begin{array}{c}\text { ABR Power } \\
\text { (MWth) }\end{array}$} & \multicolumn{2}{|c|}{ Metal Fuel } & \multicolumn{2}{|c|}{ Oxide Fuel } \\
\hline & $\begin{array}{c}\text { Heavy Metal } \\
\text { (kg.) }\end{array}$ & Assemblies & $\begin{array}{c}\text { Heavy Metal } \\
\text { (kg.) }\end{array}$ & Assemblies \\
\hline 250 & 850 & 24 & 890 & 24 \\
\hline 1000 & 3100 & 45 & 2500 & 36 \\
\hline 2000 & 5560 & 110 & 5760 & 110 \\
\hline
\end{tabular}

\subsection{Effluents from Operations}

Table 9 provides estimated activities of significant radionuclides in the liquid radioactive waste effluent. Liquid radioactive waste comes from rinses to clean radioactivity and residual sodium from components removed from the primary and intermediate systems, plus liquid from floor drains, shower drains, and laboratory drains. The concentrations given in Table 9 assume that, after distillation and demineralization, a decontamination factor of $10^{5}$ is achieved. Effluent radioactivity is assumed to scale approximately linearly with reactor power. This estimate is based upon the CRBRP evaluation of concentration of radionuclides in the effluent from the liquid radwaste systems ([CRBRP, 1977], Table 3.5-3), which assumed the effluent would be diluted by mixing with the blowdown from the wet cooling tower. If a dry cooling tower is used instead for the ABR plant, radioactive effluent will either need to be diluted by some other means or will need to be transported off-site for dilution and release. 


\begin{tabular}{|c|c|c|c|}
\hline Isotope & $\begin{array}{c}250 \text { MWth ABR } \\
(\mu \mathrm{Ci} / \mathrm{cc})\end{array}$ & $\begin{array}{c}1000 \text { MWth ABR } \\
(\mu \mathrm{Ci} / \mathrm{cc})\end{array}$ & $\begin{array}{c}2000 \text { MWth ABR } \\
(\mu \mathrm{Ci} / \mathrm{cc})\end{array}$ \\
\hline H-3 & $2.06 \times 10^{-9}$ & $8.24 \times 10^{-9}$ & $1.65 \times 10^{-8}$ \\
\hline $\mathrm{Na}-22$ & $1.77 \times 10^{-14}$ & $7.09 \times 10^{-14}$ & $1.42 \times 10^{-13}$ \\
\hline $\mathrm{Na}-24$ & $5.05 \times 10^{-15}$ & $2.02 \times 10^{-14}$ & $4.04 \times 10^{-14}$ \\
\hline $\mathrm{Cr}-51$ & $1.42 \times 10^{-13}$ & $5.68 \times 10^{-13}$ & $1.14 \times 10^{-12}$ \\
\hline Mn-54 & $1.00 \times 10^{-12}$ & $4.00 \times 10^{-12}$ & $8.00 \times 10^{-12}$ \\
\hline Co-58 & $6.15 \times 10^{-13}$ & $2.46 \times 10^{-12}$ & $4.92 \times 10^{-12}$ \\
\hline $\mathrm{Fe}-59$ & $4.93 \times 10^{-15}$ & $1.97 \times 10^{-14}$ & $3.94 \times 10^{-14}$ \\
\hline Co-60 & $9.83 \times 10^{-13}$ & $3.93 \times 10^{-12}$ & $7.86 \times 10^{-12}$ \\
\hline Sr-89 & $1.13 \times 10^{-13}$ & $4.51 \times 10^{-13}$ & $9.02 \times 10^{-13}$ \\
\hline $\mathrm{Y}-89 \mathrm{~m}$ & $1.13 \times 10^{-13}$ & $4.51 \times 10^{-13}$ & $9.02 \times 10^{-13}$ \\
\hline Sr-90 & $8.10 \times 10^{-14}$ & $3.24 \times 10^{-13}$ & $6.48 \times 10^{-13}$ \\
\hline$Y-90$ & $8.10 \times 10^{-14}$ & $3.24 \times 10^{-13}$ & $6.48 \times 10^{-13}$ \\
\hline$Y-91$ & $1.66 \times 10^{-13}$ & $6.63 \times 10^{-13}$ & $1.33 \times 10^{-12}$ \\
\hline Zr-95 & $3.13 \times 10^{-13}$ & $1.25 \times 10^{-12}$ & $2.50 \times 10^{-12}$ \\
\hline $\mathrm{Nb}-95$ & $3.13 \times 10^{-13}$ & $1.25 \times 10^{-12}$ & $2.50 \times 10^{-12}$ \\
\hline Mo-99 & $3.53 \times 10^{-14}$ & $1.41 \times 10^{-13}$ & $2.82 \times 10^{-13}$ \\
\hline Ru-103 & $4.33 \times 10^{-13}$ & $1.73 \times 10^{-12}$ & $3.46 \times 10^{-12}$ \\
\hline Ru-106 & $3.35 \times 10^{-13}$ & $1.34 \times 10^{-12}$ & $2.68 \times 10^{-12}$ \\
\hline Rh-106 & $3.35 \times 10^{-13}$ & $1.34 \times 10^{-12}$ & $2.68 \times 10^{-12}$ \\
\hline Ag-111 & $1.15 \times 10^{-14}$ & $4.58 \times 10^{-14}$ & $9.16 \times 10^{-14}$ \\
\hline Sb-125 & $4.68 \times 10^{-16}$ & $1.87 \times 10^{-15}$ & $3.74 \times 10^{-15}$ \\
\hline Te-129m & $5.73 \times 10^{-16}$ & $2.29 \times 10^{-15}$ & $4.58 \times 10^{-15}$ \\
\hline Te-129 & $5.73 \times 10^{-16}$ & $2.29 \times 10^{-15}$ & $4.58 \times 10^{-15}$ \\
\hline $\mathrm{I}-131$ & $2.17 \times 10^{-14}$ & $8.68 \times 10^{-14}$ & $1.74 \times 10^{-13}$ \\
\hline Te-132 & $3.88 \times 10^{-15}$ & $1.55 \times 10^{-14}$ & $3.10 \times 10^{-14}$ \\
\hline $\mathrm{I}-132$ & $3.88 \times 10^{-15}$ & $1.55 \times 10^{-14}$ & $3.10 \times 10^{-14}$ \\
\hline Cs-134 & $2.20 \times 10^{-15}$ & $8.78 \times 10^{-15}$ & $1.76 \times 10^{-14}$ \\
\hline Cs-136 & $9.88 \times 10^{-15}$ & $3.95 \times 10^{-14}$ & $7.90 \times 10^{-14}$ \\
\hline Cs-137 & $3.93 \times 10^{-14}$ & $1.57 \times 10^{-13}$ & $3.14 \times 10^{-13}$ \\
\hline $\mathrm{Ba}-140$ & $2.27 \times 10^{-13}$ & $9.07 \times 10^{-13}$ & $1.81 \times 10^{-12}$ \\
\hline La-140 & $2.27 \times 10^{-13}$ & $9.07 \times 10^{-13}$ & $1.81 \times 10^{-12}$ \\
\hline $\mathrm{Ce}-141$ & $3.73 \times 10^{-13}$ & $1.49 \times 10^{-12}$ & $2.98 \times 10^{-12}$ \\
\hline Pr-143 & $1.96 \times 10^{-13}$ & $7.83 \times 10^{-13}$ & $1.57 \times 10^{-12}$ \\
\hline $\mathrm{Ce}-144$ & $2.65 \times 10^{-13}$ & $1.06 \times 10^{-12}$ & $2.12 \times 10^{-12}$ \\
\hline Pr-144 & $2.65 \times 10^{-13}$ & $1.06 \times 10^{-12}$ & $2.12 \times 10^{-12}$ \\
\hline $\mathrm{Nd}-147$ & $8.20 \times 10^{-14}$ & $3.28 \times 10^{-13}$ & $6.56 \times 10^{-13}$ \\
\hline Pm-147 & $1.52 \times 10^{-13}$ & $6.06 \times 10^{-13}$ & $1.21 \times 10^{-12}$ \\
\hline Eu-155 & $1.50 \times 10^{-14}$ & $5.99 \times 10^{-14}$ & $1.20 \times 10^{-13}$ \\
\hline Ta-182 & $1.18 \times 10^{-13}$ & $4.7 \times 10^{-13}$ & $9.4 \times 10^{-13}$ \\
\hline $\mathrm{Pu}-239$ & $2.09 \times 10^{-16}$ & $8.35 \times 10^{-16}$ & $1.67 \times 10^{-15}$ \\
\hline $\mathrm{Pu}-240$ & $2.73 \times 10^{-16}$ & $1.09 \times 10^{-15}$ & $2.18 \times 10^{-15}$ \\
\hline $\mathrm{Pu}-241$ & $2.29 \times 10^{-14}$ & $9.14 \times 10^{-14}$ & $1.83 \times 10^{-13}$ \\
\hline $\mathrm{Pu}-242$ & $5.80 \times 10^{-19}$ & $2.32 \times 10^{-18}$ & $4.64 \times 10^{-18}$ \\
\hline
\end{tabular}


4.3 Air Emissions from Operations

\subsubsection{Radionuclide Emissions}

Table 10 gives estimated annual gaseous emissions for significant radionuclides, based on expected annual releases calculated for CRBR ([CRBRP, 1977], Table 3.5-8). Releases are assumed to scale approximately linearly with reactor power.

\subsubsection{Hazardous Air Pollutants}

The only air pollutants emitted from the plant result from testing or emergency operation of the emergency generators and use of diesel-powered equipment for grounds maintenance. Releases from monthly testing are presented in Table 11, assuming the generators are diesel. Appendix A provides details of how the pollutant quantities were estimated. All pollutants are covered by the National Ambient Air Quality Standards of the U.S. Environmental Protection Agency.

\begin{tabular}{|l|l|l|l|}
\hline \multicolumn{5}{|c|}{ Table 10. Estimated Annual Gaseous Radionuclide Emissions from the ABR } \\
\hline Radionuclide & $\begin{array}{c}\text { Total Release from } \\
\text { 250 MWth ABR, Ci }\end{array}$ & $\begin{array}{c}\text { Total Release from } \\
\text { 1000 MWth ABR, Ci }\end{array}$ & $\begin{array}{c}\text { Total Release from } \\
\text { 2000 MWth ABR, Ci }\end{array}$ \\
\hline Xe-131 m & $1.28 \times 10^{-3}$ & $5.1 \times 10^{-3}$ & $1.02 \times 10^{-2}$ \\
\hline $\mathrm{Xe}-133 \mathrm{~m}$ & $8.0 \times 10^{-3}$ & $3.2 \times 10^{-2}$ & $6.4 \times 10^{-2}$ \\
\hline $\mathrm{Xe}-133$ & 0.145 & 0.58 & 1.16 \\
\hline $\mathrm{Xe}-135 \mathrm{~m}$ & 0.01 & 0.04 & 0.08 \\
\hline $\mathrm{Xe}-135$ & 0.6 & 2.4 & 4.8 \\
\hline $\mathrm{Xe}-138$ & 0.017 & 0.066 & 0.132 \\
\hline $\mathrm{Kr}-83 \mathrm{~m}$ & 0.017 & 0.066 & 0.132 \\
\hline $\mathrm{Kr}-85 \mathrm{~m}$ & 0.045 & 0.18 & 0.36 \\
\hline $\mathrm{Kr}-85$ & $5.75 \times 10^{-4}$ & $2.3 \times 10^{-3}$ & $4.6 \times 10^{-3}$ \\
\hline $\mathrm{Kr}-87$ & 0.0375 & 0.15 & 0.3 \\
\hline $\mathrm{Kr}-88$ & 0.08 & 0.32 & 0.64 \\
\hline $\mathrm{Ar}-39^{*}$ & 0.3 & 1.2 & 2.4 \\
\hline $\mathrm{Ar}-41^{*}$ & 0.011 & 0.044 & 0.088 \\
\hline $\mathrm{Ne}-23^{*}$ & $4.75 \times 10^{-3}$ & $1.9 \times 10^{-2}$ & $3.8 \times 10^{-2}$ \\
\hline $\mathrm{H}-3^{*}$ & 0.17 & 0.66 & 1.32 \\
\hline Total & 1.5 & 5.8 & 11.6 \\
\hline$*$ & & \\
\hline
\end{tabular}

${ }^{*}$ Release rate independent of failed fuel fraction

\begin{tabular}{|c|c|c|c|}
\hline \multicolumn{3}{|c|}{ Table 11. ABR Estimated Annual Release of Hazardous Air Pollutants } \\
\hline \multirow{2}{*}{ Pollutant } & \multicolumn{3}{|c|}{ Annual Release (tons) } \\
\cline { 2 - 4 } & 250 MWth & 1000 MWth & 2000 MWth \\
\hline $\mathrm{SO}_{2}$ & 4.1 & 5.5 & 7.1 \\
\hline Hydrocarbons & 4.1 & 5.5 & 7.1 \\
\hline $\mathrm{NO}_{\mathrm{x}}$ & 41 & 45 & 71 \\
\hline $\mathrm{CO}$ & 8.2 & 11.0 & 14.1 \\
\hline
\end{tabular}


4.4 Transportation

\subsubsection{Transportation Data for Shipment of Wastes}

Estimated numbers of 55-gallon drums of solid radioactive waste which would be generated annually are provided in Table 12, based upon estimates for CRBR [CRBRP, 1977]. These quantities are consistent with the waste volumes discussed in Table 3. See Appendix A for calculation details.

Control rod assemblies, control rod assembly lines (cut to fit in the shipping cask), and radial shield assemblies can probably be shipped in any of several currently licensed shipping casks for radioactive materials.

Sanitary waste sludge and non-hazardous solid waste would be transported off site to commercial processing and/or disposal facilities.

\subsubsection{Physics Data for Transportation of Spent Startup Driver Fuel}

Several options for spent startup driver fuel from the ABR are currently being considered. These include 1) storing the spent fuel in the ABR Fuel Storage Facility indefinitely, 2) reprocessing the fuel in an on-site reprocessing facility, or 3) shipping the spent fuel off site for processing. If the fuel is shipped off site for processing periodically, the decay heat and isotopic composition of the spent fuel as a function of time after discharge must be evaluated against the heat and radiation limits of the spent fuel shipping casks. Table 13. lists decay heat per assembly as a function of time for both metal and oxide fuels at peak discharge burnup from the $250 \mathrm{MWth}, 1000 \mathrm{MWth}$, and $2000 \mathrm{MWth}$ cores. [Kim, 2007a] Tables 14 through 25 display, for each of the six candidate cores, isotopic mass per assembly of heavy metal nuclides and of fission products which are the dominant contributors to decay heat over the first ten years of post-irradiation cooling. [Kim, 2007a]

\begin{tabular}{|c|c|c|c|}
\hline \multicolumn{4}{|c|}{ Table 12. Annual Estimated Low-Level Waste from the ABR } \\
\hline \multirow{2}{*}{ Waste Type } & \multicolumn{3}{|c|}{ Number of 55-Gallon Drums } \\
\cline { 2 - 4 } & $\mathbf{2 5 0}$ MWth & $\mathbf{1 0 0 0}$ MWth & $\mathbf{2 0 0 0}$ MWth \\
\hline Compactible solids & 28 & 28 & 28 \\
\hline Non-compactible solids & 155 & 155 & 155 \\
\hline Solidified liquid radwaste & 35 & 140 & 280 \\
\hline
\end{tabular}


ANL-AFCI-183, Rev. 0.5

Argonne

Preliminary NEPA Data Study

\begin{tabular}{|c|c|c|c|c|c|c|}
\hline \multirow[t]{3}{*}{ Time } & \multicolumn{6}{|c|}{ Decay Heat (kW) } \\
\hline & \multicolumn{2}{|c|}{$250 \mathrm{MW}$ th ABR } & \multicolumn{2}{|c|}{1000 MWth ABR } & \multicolumn{2}{|c|}{2000 MWth ABR } \\
\hline & Metal & Oxide & Metal & Oxide & Metal & Oxide \\
\hline discharge & 227.4 & 227.1 & 300.6 & 281.4 & 334.1 & 329.3 \\
\hline 30 days & 10.5 & 10.6 & 9.3 & 8.6 & 10.0 & 10.1 \\
\hline 1 year & 2.9 & 3.0 & 5.9 & 5.5 & 2.6 & 2.6 \\
\hline 2 years & 1.4 & 1.5 & 2.6 & 2.4 & 1.3 & 1.4 \\
\hline 3 years & 1.0 & 1.0 & 1.4 & 1.3 & 0.8 & 0.8 \\
\hline 5 years & 0.7 & 0.7 & 0.8 & 0.8 & 0.4 & 0.4 \\
\hline 10 years & 0.6 & 0.6 & 0.4 & 0.5 & 0.2 & 0.2 \\
\hline 15 years & 0.5 & 0.6 & 0.3 & 0.3 & 0.2 & 0.2 \\
\hline 20 years & 0.5 & 0.6 & 0.2 & 0.3 & 0.2 & 0.2 \\
\hline
\end{tabular}

\begin{tabular}{|c|c|c|c|c|c|c|c|c|c|}
\hline \multirow[t]{2}{*}{ Isotope } & \multicolumn{9}{|c|}{ Mass per Assembly (g.) } \\
\hline & discharge & 30 days & $1 \mathrm{yr}$. & $2 \mathrm{yr}$. & $3 \mathrm{yr}$. & $5 \mathrm{yr}$. & $10 \mathrm{yr}$. & $15 \mathrm{yr}$. & $20 \mathrm{yr}$. \\
\hline U-234 & 6.51 & 6.77 & 9.76 & 13.10 & 16.44 & 23.05 & 39.14 & 54.63 & 69.53 \\
\hline U-235 & 21.57 & 21.58 & 21.73 & 21.89 & 22.06 & 22.38 & 23.19 & 24.01 & 24.82 \\
\hline U-236 & 4.25 & 4.28 & 4.63 & 5.01 & 5.39 & 6.16 & 8.06 & 9.97 & 11.88 \\
\hline U-237 & 0.08 & $3.8 \mathrm{E}-03$ & $2.5 \mathrm{E}-05$ & $2.4 \mathrm{E}-05$ & $2.3 \mathrm{E}-05$ & $2.1 \mathrm{E}-05$ & $1.6 \mathrm{E}-05$ & $1.3 \mathrm{E}-05$ & $1.0 \mathrm{E}-05$ \\
\hline U-238 & 17077.25 & 17077.25 & 17077.25 & 17077.25 & 17077.25 & 17077.25 & 17077.25 & 17077.25 & 17077.25 \\
\hline Np-237 & 486.14 & 486.49 & 487.18 & 488.56 & 489.60 & 492.02 & 498.94 & 506.89 & 515.53 \\
\hline Np-239 & 3.77 & $6.9 \mathrm{E}-04$ & $1.4 \mathrm{E}-04$ & $1.4 \mathrm{E}-04$ & $1.4 \mathrm{E}-04$ & $1.4 \mathrm{E}-04$ & $1.4 \mathrm{E}-04$ & $1.4 \mathrm{E}-04$ & $1.4 \mathrm{E}-04$ \\
\hline $\mathrm{Pu}-238$ & 402.81 & 407.31 & 427.71 & 430.48 & 428.40 & 422.18 & 406.62 & 391.40 & 376.88 \\
\hline $\mathrm{Pu}-239$ & 5743.13 & 5746.59 & 5746.59 & 5746.59 & 5746.59 & 5746.59 & 5743.13 & 5743.13 & 5743.13 \\
\hline $\mathrm{Pu}-240$ & 7.80 & 3647.80 & 3647.80 & 3651.26 & 3651.26 & 3654.72 & 3661.63 & 3665.09 & 3668.55 \\
\hline $\mathrm{Pu}-241$ & 2.97 & 839.51 & 803.21 & 765.52 & 729.56 & 662.48 & 520.72 & 409.38 & 321.87 \\
\hline $\mathrm{Pu}-242$ & 755.84 & 755.84 & 755.84 & 755.84 & 755.84 & 755.84 & 756.18 & 756.18 & 756.18 \\
\hline Am-241 & 642.08 & 645.54 & 680.81 & 717.46 & 752.04 & 816.69 & 951.19 & 1054.58 & 1133.41 \\
\hline Am-242m & 32.73 & 32.72 & 32.58 & 32.43 & 32.28 & 31.99 & 31.27 & 30.57 & 29.88 \\
\hline Am-243 & 162.27 & 162.27 & 162.27 & 162.23 & 162.23 & 162.20 & 162.13 & 162.06 & 161.96 \\
\hline $\mathrm{Cm}-242$ & 35.86 & 31.71 & 7.69 & 1.69 & 0.42 & 0.09 & 0.08 & 0.07 & 0.07 \\
\hline $\mathrm{Cm}-243$ & 1.37 & 1.36 & 1.33 & 1.30 & 1.27 & 1.21 & 1.07 & 0.95 & 0.84 \\
\hline $\mathrm{Cm}-244$ & 52.56 & 52.42 & 50.62 & 48.72 & 46.89 & 43.43 & 35.86 & 29.61 & 24.46 \\
\hline $\mathrm{Cm}-245$ & 6.17 & 6.17 & 6.17 & 6.17 & 6.16 & 6.16 & 6.16 & 6.16 & 6.16 \\
\hline
\end{tabular}


ANL-AFCI-183, Rev. 0.5

Preliminary NEPA Data Study

Argonne

Table 15. Fission Product Isotopic Masses at Peak Discharge Burnup of 250 MWth ABR Spent Metal Fuel

\begin{tabular}{|l|r|r|r|r|r|r|r|r|r|}
\hline Isotope & \multicolumn{10}{|c|}{ Mass per Assembly (g.) } \\
\hline & discharge & 30 days & \multicolumn{1}{|c|}{1 yr. } & 2 yr. & \multicolumn{1}{|c|}{ yr. } & \multicolumn{1}{c|}{5 yr. } & \multicolumn{1}{c|}{10 yr. } & \multicolumn{1}{c|}{15 yr. } & \multicolumn{1}{c|}{20 yr. } \\
\hline Kr-85 & 1.97 & 1.96 & 1.84 & 1.73 & 1.62 & 1.42 & 1.03 & 0.75 & 0.54 \\
\hline Y-90 & $9.5 \mathrm{E}-03$ & $8.8 \mathrm{E}-03$ & $8.6 \mathrm{E}-03$ & $8.4 \mathrm{E}-03$ & $8.2 \mathrm{E}-03$ & $7.8 \mathrm{E}-03$ & $7.0 \mathrm{E}-03$ & $6.2 \mathrm{E}-03$ & $5.5 \mathrm{E}-03$ \\
\hline Sr-90 & 35.20 & 35.13 & 34.39 & 33.58 & 32.79 & 31.26 & 27.75 & 24.64 & 21.88 \\
\hline Rh-106 & $3.7 \mathrm{E}-05$ & $3.5 \mathrm{E}-05$ & $1.9 \mathrm{E}-05$ & $9.4 \mathrm{E}-06$ & $4.7 \mathrm{E}-06$ & $1.2 \mathrm{E}-06$ & $3.8 \mathrm{E}-08$ & $1.2 \mathrm{E}-09$ & $3.9 \mathrm{E}-11$ \\
\hline Ag-108m & $5.7 \mathrm{E}-07$ & $5.7 \mathrm{E}-07$ & $5.6 \mathrm{E}-07$ & $5.6 \mathrm{E}-07$ & $5.6 \mathrm{E}-07$ & $5.5 \mathrm{E}-07$ & $5.4 \mathrm{E}-07$ & $5.2 \mathrm{E}-07$ & $5.1 \mathrm{E}-07$ \\
\hline Sb-125 & 3.26 & 3.21 & 2.56 & 1.99 & 1.55 & 0.94 & 0.27 & 0.08 & 0.02 \\
\hline Te-125m & 0.04 & 0.04 & 0.04 & 0.03 & 0.02 & $1.3 \mathrm{E}-02$ & $3.8 \mathrm{E}-03$ & $1.1 \mathrm{E}-03$ & $3.1 \mathrm{E}-04$ \\
\hline Cs-134 & 7.02 & 6.83 & 5.02 & 3.59 & 2.56 & 1.31 & 0.24 & 0.05 & 0.01 \\
\hline Cs-137 & 159.92 & 159.60 & 156.25 & 152.69 & 149.20 & 142.45 & 126.93 & 113.06 & 100.76 \\
\hline Ba-137m & $2.5 \mathrm{E}-05$ & $2.4 \mathrm{E}-05$ & $2.4 \mathrm{E}-05$ & $2.3 \mathrm{E}-05$ & $2.3 \mathrm{E}-05$ & $2.2 \mathrm{E}-05$ & $1.9 \mathrm{E}-05$ & $1.7 \mathrm{E}-05$ & $1.5 \mathrm{E}-05$ \\
\hline Pr-144 & $1.5 \mathrm{E}-03$ & $1.4 \mathrm{E}-03$ & $6.2 \mathrm{E}-04$ & $2.5 \mathrm{E}-04$ & $1.0 \mathrm{E}-04$ & $1.8 \mathrm{E}-05$ & $2.0 \mathrm{E}-07$ & $2.4 \mathrm{E}-09$ & $2.8 \mathrm{E}-11$ \\
\hline Sm-147 & 14.57 & 15.27 & 22.18 & 28.03 & 32.52 & 38.62 & 45.02 & 46.75 & 47.20 \\
\hline Pm-147 & 31.88 & 31.96 & 25.19 & 19.34 & 14.85 & 8.75 & 2.34 & 0.62 & 0.17 \\
\hline Sm-151 & 19.86 & 19.88 & 19.75 & 19.59 & 19.45 & 19.15 & 18.42 & 17.73 & 17.06 \\
\hline Eu-154 & 2.16 & 2.15 & 2.00 & 1.84 & 1.70 & 1.45 & 0.97 & 0.65 & 0.43 \\
\hline Eu-155 & 4.60 & 4.54 & 4.00 & 3.47 & 3.02 & 2.28 & 1.14 & 0.56 & 0.28 \\
\hline
\end{tabular}

\begin{tabular}{|c|c|c|c|c|c|c|c|c|c|}
\hline \multicolumn{10}{|c|}{$\begin{array}{l}\text { Table 16. Actinide Isotopic Masses at Peak Discharge Burnup of } 250 \text { MWth ABR Spent Oxide } \\
\text { Fuel }\end{array}$} \\
\hline \multirow[t]{2}{*}{ Isotope } & \multicolumn{9}{|c|}{ Mass per Assembly (g.) } \\
\hline & discharge & 30 days & $1 \mathrm{yr}$. & $2 \mathrm{yr}$. & $3 \mathrm{yr}$. & $5 \mathrm{yr}$. & $10 \mathrm{yr}$. & $15 \mathrm{yr}$. & $20 \mathrm{yr}$. \\
\hline U-234 & 7.28 & 7.57 & 10.90 & 14.61 & 18.32 & 25.66 & 43.52 & 60.73 & 77.30 \\
\hline U-235 & 23.47 & 23.49 & 23 & 23 & 23 & 24.34 & & 26.07 & 26.93 \\
\hline U-236 & 5.00 & 5.04 & 5.41 & 5.82 & 6.22 & 7.04 & 9.07 & 11.12 & 13.16 \\
\hline $\mathrm{U}-237$ & $8.6 \mathrm{E}-02$ & $4.0 \mathrm{E}-03$ & 2.7E-05 & $2.5 \mathrm{E}-05$ & $2.4 \mathrm{E}-05$ & $2.2 \mathrm{E}-05$ & $1.7 \mathrm{E}-05$ & $1.4 \mathrm{E}-05$ & $1.1 \mathrm{E}-05$ \\
\hline $\mathrm{U}-238$ & 18932.27 & 18932.27 & 18932.27 & 18932.27 & 18932.27 & 18932.27 & 18932.27 & 18932.27 & 18932.27 \\
\hline Np-237 & 490.85 & 490.85 & 491.97 & 493.09 & 494.21 & 496.82 & 504.29 & 512.50 & 521.46 \\
\hline Np-239 & 4.35 & $7.9 \mathrm{E}-04$ & $1.5 \mathrm{E}-04$ & $1.5 \mathrm{E}-04$ & $1.5 \mathrm{E}-04$ & $1.5 \mathrm{E}-04$ & $1.5 \mathrm{E}-04$ & $1.5 \mathrm{E}-04$ & $1.5 \mathrm{E}-04$ \\
\hline $\mathrm{Pu}-238$ & 447.92 & 452.78 & 475.55 & 478.16 & 475.92 & 469.20 & 451.66 & 434.86 & 418.44 \\
\hline $\mathrm{Pu}-239$ & 6099.24 & 610 & 6102.97 & 6102.97 & 61 & 61 & 6099.24 & 6099.24 & 6099.24 \\
\hline $\mathrm{Pu}-240$ & 3896.94 & 3896.94 & 3900.68 & 3900.68 & 3900.68 & 3904.41 & 391 & 3915.61 & 3919.34 \\
\hline $\mathrm{Pu}-241$ & 902.19 & 898.84 & 860.01 & 819.33 & 780.88 & 709.21 & 557 & 438.22 & 344.53 \\
\hline $\mathrm{Pu}-242$ & 799.55 & 799.55 & 799.55 & 799.55 & 799.55 & 799.92 & 799.92 & 799.92 & 800.29 \\
\hline Am-241 & 658.45 & 661.81 & 699.88 & 739.08 & 776.40 & 845.46 & 989.54 & 1100.40 & 1185.13 \\
\hline Am-242m & 35.63 & 35.61 & 35.47 & 35.30 & 35.14 & 34.83 & 34.04 & 33.27 & 32.52 \\
\hline Am-243 & 173.57 & 173.61 & 173.57 & 173.57 & 173.53 & 173.50 & 173.42 & 173.35 & 173.27 \\
\hline Cm-242 & 39.23 & 34.69 & 8.42 & 1.85 & 0.46 & 0.10 & 0.08 & 0.08 & 0.08 \\
\hline $\mathrm{Cm}-243$ & 1.84 & 1.84 & 1.79 & 1.75 & 1.71 & 1.63 & 1.44 & 1.28 & 1.13 \\
\hline $\mathrm{Cm}-244$ & 59.69 & 59.54 & 57.48 & 55.32 & 53.23 & 49.31 & 40.72 & 33.64 & 27.78 \\
\hline $\mathrm{Cm}-245$ & 7.33 & 7.33 & 7.32 & 7.32 & 7.32 & 7.32 & 7.32 & 7.32 & 7.31 \\
\hline
\end{tabular}


ANL-AFCI-183, Rev. 0.5

Preliminary NEPA Data Study

Argonne

Table 17. Fission Product Isotopic Masses at Peak Discharge Burnup of 250 MWth ABR Spent Oxide Fuel

\begin{tabular}{|c|c|c|c|c|c|c|c|c|c|}
\hline Isotope & \multicolumn{9}{|c|}{ Mass per Assembly (g.) } \\
\hline & discharge & 30 days & $1 \mathrm{yr}$. & $2 \mathrm{yr}$ & 3 yr. & $5 \mathrm{yr}$. & $10 \mathrm{yr}$. & $15 \mathrm{yr}$. & $20 \mathrm{yr}$. \\
\hline $\mathrm{Kr}-85$ & 2.00 & 1.99 & 1.87 & 1.76 & 1.65 & 1.45 & 1.05 & 0.76 & 0.55 \\
\hline Y-90 & $9.6 \mathrm{E}-03$ & $9.0 \mathrm{E}-03$ & $8.8 \mathrm{E}-03$ & $8.6 \mathrm{E}-03$ & $8.4 \mathrm{E}-03$ & $8.0 \mathrm{E}-03$ & $7.1 \mathrm{E}-03$ & $6.3 \mathrm{E}-03$ & $5.6 \mathrm{E}-03$ \\
\hline $\mathrm{Sr}-90$ & 35.89 & 35.82 & 35.05 & 34.23 & 33.42 & 31.87 & 28.29 & 25.12 & 22.30 \\
\hline Rh-106 & $3.7 \mathrm{E}-05$ & $3.5 \mathrm{E}-05$ & $1.9 \mathrm{E}-05$ & 9.4E-06 & 4.7E-06 & $1.2 \mathrm{E}-06$ & $3.9 \mathrm{E}-08$ & $1.2 \mathrm{E}-09$ & 4.0E-11 \\
\hline $\mathrm{Ag}-108 \mathrm{~m}$ & $5.7 \mathrm{E}-07$ & $5.7 \mathrm{E}-07$ & $5.7 \mathrm{E}-07$ & $5.7 \mathrm{E}-07$ & $5.6 \mathrm{E}-07$ & $5.6 \mathrm{E}-07$ & $5.4 \mathrm{E}-07$ & $5.3 \mathrm{E}-07$ & $5.1 \mathrm{E}-07$ \\
\hline Sb-125 & 3.32 & 3.27 & 2.60 & 2.02 & 1.58 & 0.96 & 0.27 & 0.08 & 0.02 \\
\hline Te-125m & 0.04 & 0.04 & 0.04 & 0.03 & 0.02 & $1.3 \mathrm{E}-02$ & $3.8 \mathrm{E}-03$ & $1.1 \mathrm{E}-03$ & $3.1 \mathrm{E}-04$ \\
\hline Cs-134 & 6.72 & 6.54 & 4.80 & 3.43 & 2.45 & 1.25 & 0.23 & 0.04 & 0.01 \\
\hline Cs-137 & 163.04 & 162.75 & 159.35 & 155.69 & 152.15 & 145.28 & 129.41 & 115.30 & 102.72 \\
\hline Ba-137m & $2.5 \mathrm{E}-05$ & $2.5 \mathrm{E}-05$ & $2.4 \mathrm{E}-05$ & $2.4 \mathrm{E}-05$ & $2.3 \mathrm{E}-05$ & $2.2 \mathrm{E}-05$ & $2.0 \mathrm{E}-05$ & $1.8 \mathrm{E}-05$ & $1.6 \mathrm{E}-05$ \\
\hline Pr-144 & $1.5 \mathrm{E}-03$ & $1.4 \mathrm{E}-03$ & $6.2 \mathrm{E}-04$ & $2.5 \mathrm{E}-04$ & $1.0 \mathrm{E}-04$ & $1.8 \mathrm{E}-05$ & $2.1 \mathrm{E}-07$ & $2.4 \mathrm{E}-09$ & $2.8 \mathrm{E}-11$ \\
\hline Sm-147 & 15.32 & 16.04 & 23.15 & 29.17 & 33.79 & 40.05 & 46.66 & 48.45 & 48.90 \\
\hline Pm-147 & 32.84 & 32.90 & 25.92 & 19.91 & 15.28 & 9.01 & 2.40 & 0.64 & 0.17 \\
\hline Sm-151 & 20.48 & 20.51 & 20.37 & 20.21 & 20.06 & 19.75 & 19.00 & 18.28 & 17.59 \\
\hline Eu-154 & 2.11 & 2.09 & 1.95 & 1.79 & 1.66 & 1.41 & 0.94 & 0.63 & 0.42 \\
\hline Eu-155 & 4.69 & 4.64 & 4.08 & 3.55 & 3.08 & 2.33 & 1.16 & 0.58 & 0.29 \\
\hline
\end{tabular}

Table 18. Actinide Isotopic Masses at Peak Discharge Burnup of 1000 MWth ABR Spent Metal Fuel

\begin{tabular}{|c|c|c|c|c|c|c|c|c|c|}
\hline Isotope & \multicolumn{9}{|c|}{ Mass per Assembly (g.) } \\
\hline & discharge & 30 days & $1 \mathrm{yr}$. & $2 \mathrm{yr}$. & $3 \mathrm{yr}$. & $5 \mathrm{yr}$. & $10 \mathrm{yr}$. & $15 \mathrm{yr}$. & $20 \mathrm{yr}$. \\
\hline U-234 & 0.23 & 0.24 & 0.34 & 0.46 & 0.57 & 0.80 & 1.35 & 1.88 & 2.39 \\
\hline U-235 & 40.61 & 40.62 & 40.84 & 41.06 & 41.29 & 41.74 & 42.87 & 44.00 & 45.14 \\
\hline U-236 & 16.13 & 16.14 & 16.32 & 16.51 & 16.71 & 17.09 & 18.05 & 19.01 & 19.96 \\
\hline U-237 & 0.27 & $1.3 \mathrm{E}-02$ & $5.2 \mathrm{E}-06$ & $4.9 \mathrm{E}-06$ & $4.7 \mathrm{E}-06$ & $4.3 \mathrm{E}-06$ & $3.4 \mathrm{E}-06$ & $2.6 \mathrm{E}-06$ & $2.1 \mathrm{E}-06$ \\
\hline $\mathrm{U}-238$ & 54912.55 & 54912.55 & 54912.55 & 54912.55 & 54912.55 & 54912.55 & 54912.55 & 54912.55 & 54912.55 \\
\hline $\mathrm{Np}-237$ & 33.48 & 33.74 & 33.78 & 33.83 & 33.89 & 34.05 & 34.61 & 35.36 & 36.28 \\
\hline $\mathrm{Np}-239$ & 13.21 & $1.9 \mathrm{E}-03$ & $1.4 \mathrm{E}-06$ & $1.4 \mathrm{E}-06$ & $1.4 \mathrm{E}-06$ & $1.4 \mathrm{E}-06$ & $1.4 \mathrm{E}-06$ & $1.4 \mathrm{E}-06$ & $1.4 \mathrm{E}-06$ \\
\hline Pu-238 & 13.99 & 14.14 & 14.68 & 14.74 & 14.65 & 14.44 & 13.89 & 13.37 & 12.86 \\
\hline Pu-239 & 7992.70 & 8003.58 & 8003.58 & 8003.58 & 8003.25 & 8003.25 & 8002.59 & 8002.26 & 8001.94 \\
\hline Pu-240 & 1839.94 & 1839.94 & 1839.61 & 1839.61 & 1839.18 & 1839.18 & 1838.09 & 1836.90 & 1836.14 \\
\hline Pu-241 & 175.64 & 174.96 & 167.41 & 159.57 & 152.06 & 138.08 & 108.55 & 85.32 & 67.08 \\
\hline $\mathrm{Pu}-242$ & 21.44 & 21.44 & 21.44 & 21.45 & 21.45 & 21.45 & 21.45 & 21.45 & 21.45 \\
\hline Am-241 & 18.37 & 19.06 & 26.58 & 34.40 & 41.84 & 55.64 & 84.62 & 107.05 & 124.37 \\
\hline Am-242m & 0.70 & 0.70 & 0.70 & 0.69 & 0.69 & 0.69 & 0.67 & 0.65 & 0.64 \\
\hline Am-243 & 1.62 & 1.62 & 1.62 & 1.62 & 1.62 & 1.62 & 1.62 & 1.62 & 1.62 \\
\hline Cm-242 & 0.98 & 0.87 & 0.21 & 0.05 & $1.1 \mathrm{E}-02$ & $2.1 \mathrm{E}-03$ & $1.6 \mathrm{E}-03$ & $1.6 \mathrm{E}-03$ & $1.5 \mathrm{E}-03$ \\
\hline $\mathrm{Cm}-243$ & 0.03 & 0.03 & 0.03 & 0.03 & 0.03 & 0.03 & 0.03 & 0.02 & $2.0 \mathrm{E}-02$ \\
\hline Cm-244 & 0.28 & 0.28 & 0.27 & 0.26 & 0.25 & 0.23 & 0.19 & 0.16 & 0.13 \\
\hline $\mathrm{Cm}-245$ & 0.02 & 0.02 & 0.02 & 0.02 & 0.02 & 0.02 & 0.02 & 0.02 & $2.4 \mathrm{E}-02$ \\
\hline
\end{tabular}




\begin{tabular}{|l|r|r|r|r|r|r|r|r|r|r|}
\hline Table 19. Fission Product Isotopic Masses at Peak Discharge Burnup of 1000 MWth ABR \\
Spent Metal Fuel \\
\hline Isotope & \multicolumn{10}{|c|}{ Mass per Assembly $(\mathrm{g})}$. \\
\hline & discharge & 30 days & 1 yr. & 2 yr. & 3 yr. & \multicolumn{1}{|c|}{ yr. } & 10 yr. & 15 yr. & 20 yr. \\
\hline Kr-85 & 4.80 & 4.77 & 4.50 & 4.22 & 3.95 & 3.47 & 2.51 & 1.82 & 1.32 \\
\hline Y-90 & $2.4 \mathrm{E}-02$ & $2.2 \mathrm{E}-02$ & $2.1 \mathrm{E}-02$ & $2.1 \mathrm{E}-02$ & $2.0 \mathrm{E}-02$ & $1.9 \mathrm{E}-02$ & $1.7 \mathrm{E}-02$ & $1.5 \mathrm{E}-02$ & $1.4 \mathrm{E}-02$ \\
\hline Sr-90 & 87.02 & 86.83 & 84.99 & 82.99 & 80.99 & 77.28 & 68.59 & 60.90 & 54.07 \\
\hline Rh-106 & $5.1 \mathrm{E}-05$ & $4.8 \mathrm{E}-05$ & $2.5 \mathrm{E}-05$ & $1.3 \mathrm{E}-05$ & $6.4 \mathrm{E}-06$ & $1.6 \mathrm{E}-06$ & $5.2 \mathrm{E}-08$ & $1.7 \mathrm{E}-09$ & $5.4 \mathrm{E}-11$ \\
\hline Ag-108m & $1.4 \mathrm{E}-06$ & $1.4 \mathrm{E}-06$ & $1.4 \mathrm{E}-06$ & $1.4 \mathrm{E}-06$ & $1.4 \mathrm{E}-06$ & $1.4 \mathrm{E}-06$ & $1.3 \mathrm{E}-06$ & $1.3 \mathrm{E}-06$ & $1.2 \mathrm{E}-06$ \\
\hline Sb-125 & 0.03 & $3.4 \mathrm{E}-03$ & $1.2 \mathrm{E}-13$ & $4.6 \mathrm{E}-25$ & $1.8 \mathrm{E}-36$ & 0.00 & 0.00 & 0.00 & 0.00 \\
\hline Te-125m & 0.09 & 0.09 & 0.08 & 0.06 & 0.05 & 0.03 & $7.9 \mathrm{E}-03$ & $2.3 \mathrm{E}-03$ & $6.5 \mathrm{E}-04$ \\
\hline Cs-134 & 27.35 & 26.61 & 19.54 & 13.96 & 9.98 & 5.09 & 0.95 & 0.18 & 0.03 \\
\hline Cs-137 & 362.72 & 362.00 & 354.42 & 346.33 & 338.40 & 323.14 & 287.89 & 256.49 & 228.48 \\
\hline Ba-137m & $5.6 \mathrm{E}-05$ & $5.5 \mathrm{E}-05$ & $5.4 \mathrm{E}-05$ & $5.3 \mathrm{E}-05$ & $5.2 \mathrm{E}-05$ & $4.9 \mathrm{E}-05$ & $4.4 \mathrm{E}-05$ & $3.9 \mathrm{E}-05$ & $3.5 \mathrm{E}-05$ \\
\hline Pr-144 & $2.1 \mathrm{E}-03$ & $2.0 \mathrm{E}-03$ & $8.7 \mathrm{E}-04$ & $3.6 \mathrm{E}-04$ & $1.5 \mathrm{E}-04$ & $2.5 \mathrm{E}-05$ & $2.9 \mathrm{E}-07$ & $3.3 \mathrm{E}-09$ & $3.9 \mathrm{E}-11$ \\
\hline Sm-147 & 41.90 & 42.98 & 53.65 & 62.67 & 69.60 & 79.01 & 88.91 & 91.54 & 92.25 \\
\hline Pm-147 & 49.41 & 49.35 & 38.87 & 29.85 & 22.92 & 13.51 & 3.61 & 0.96 & 0.26 \\
\hline Sm-151 & 38.83 & 38.85 & 38.58 & 38.29 & 37.99 & 37.41 & 36.00 & 34.64 & 33.33 \\
\hline Eu-154 & 7.66 & 7.61 & 7.07 & 6.52 & 6.02 & 5.12 & 3.42 & 2.29 & 1.53 \\
\hline Eu-155 & 9.33 & 9.23 & 8.12 & 7.06 & 6.14 & 4.64 & 2.31 & 1.15 & 0.57 \\
\hline
\end{tabular}

\begin{tabular}{|c|c|c|c|c|c|c|c|c|c|}
\hline able 2 & $\begin{array}{l}\text { ctinide } \\
\text { uel }\end{array}$ & opic & ses a & $\mathrm{k} \mathbf{D i}$ & rge $B$ & ip of & MW & $3 \mathrm{R} \mathrm{S}_{\mathrm{I}}$ & Oxide \\
\hline Isotope & & & & Mass & r Assem & ly (g.) & & & \\
\hline & discharge & 30 days & $1 \mathrm{yr}$. & $2 \mathrm{yr}$. & $3 \mathrm{yr}$. & $5 \mathrm{yr}$. & $10 \mathrm{yr}$. & $15 \mathrm{yr}$. & $20 \mathrm{yr}$. \\
\hline U-234 & 0.35 & 0.37 & 0.51 & 0.67 & 0.83 & 1.15 & 1.92 & 2.66 & 3.38 \\
\hline U-235 & 35.49 & 35.51 & 35.75 & 36.01 & 36.26 & 36.78 & 38.07 & 39.36 & 40.65 \\
\hline U-236 & 18.62 & 18.64 & 18.91 & 19.19 & 19.48 & 20.06 & 21.49 & 22.93 & 24.36 \\
\hline U-237 & 0.22 & $1.0 \mathrm{E}-02$ & $9.2 \mathrm{E}-06$ & $8.7 \mathrm{E}-06$ & $8.3 \mathrm{E}-06$ & 7.6E-06 & $6.0 \mathrm{E}-06$ & 4.7E-06 & $3.7 \mathrm{E}-06$ \\
\hline U-238 & 53121.47 & 53121.47 & 53121.47 & 53121.47 & 53121.47 & 53121.47 & 53121.47 & 53121.47 & 53121.47 \\
\hline $\mathrm{Np}-237$ & 29.88 & 30.10 & 30.17 & 30.27 & 30.38 & 30.67 & 31.69 & 33.06 & 34.72 \\
\hline Np-239 & 12.90 & $1.9 \mathrm{E}-03$ & 3.3E-06 & 3.3E-06 & 3.3E-06 & 3.3E-06 & 3.3E-06 & 3.3E-06 & $3.3 \mathrm{E}-06$ \\
\hline $\mathrm{Pu}-238$ & 19.05 & 19.31 & 20.48 & 20.65 & 20.56 & 20.27 & 19.52 & 18.79 & 18.09 \\
\hline $\mathrm{Pu}-239$ & 9100.22 & 9115.84 & 9115.84 & 9115.84 & 9115.84 & 9115.84 & 9112.46 & 9108.03 & 9108.03 \\
\hline $\mathrm{Pu}-240$ & 2757.29 & 2757.29 & 2756.85 & 2756.85 & 2756.85 & 2756.07 & 2754.51 & 2753.28 & 2751.72 \\
\hline $\mathrm{Pu}-241$ & 311.15 & 309.92 & 296.55 & 282.58 & 269.28 & 244.59 & 192.27 & 151.12 & 118.80 \\
\hline $\mathrm{Pu}-242$ & 43.93 & 43.93 & 43.93 & 43.93 & 43.93 & 43.94 & 43.94 & 43.95 & 43.95 \\
\hline Am-241 & 36.65 & 37.87 & 51.21 & 65.05 & 78.21 & 102.63 & 153.93 & 193.66 & 224.28 \\
\hline $\mathrm{Am}-242 \mathrm{~m}$ & 1.51 & 1.51 & 1.50 & 1.49 & 1.49 & 1.47 & 1.44 & 1.41 & 1.37 \\
\hline Am-243 & 3.79 & 3.80 & 3.80 & 3.79 & 3.79 & 3.79 & 3.79 & 3.79 & 3.79 \\
\hline $\mathrm{Cm}-242$ & 1.99 & 1.76 & 0.43 & 0.09 & 0.02 & $4.4 \mathrm{E}-03$ & $3.5 \mathrm{E}-03$ & $3.4 \mathrm{E}-03$ & $3.3 \mathrm{E}-03$ \\
\hline $\mathrm{Cm}-243$ & 0.10 & 0.10 & 0.09 & 0.09 & 0.09 & 0.08 & 0.07 & 0.07 & 0.06 \\
\hline $\mathrm{Cm}-244$ & 0.81 & 0.81 & 0.78 & 0.75 & 0.72 & 0.67 & 0.55 & 0.46 & 0.38 \\
\hline $\mathrm{Cm}-245$ & 0.08 & 0.08 & 0.08 & 0.08 & 0.08 & 0.08 & 0.08 & 0.08 & 0.08 \\
\hline
\end{tabular}




\begin{tabular}{|c|c|c|c|c|c|c|c|c|c|}
\hline \multirow[t]{2}{*}{ Isotope } & \multicolumn{9}{|c|}{ Mass per Assembly (g.) } \\
\hline & discharge & 30 days & $1 \mathrm{yr}$. & $2 \mathrm{yr}$. & $3 \mathrm{yr}$. & $5 \mathrm{yr}$. & $10 \mathrm{yr}$. & $15 \mathrm{yr}$. & $20 \mathrm{yr}$. \\
\hline $\mathrm{Kr}-85$ & 5.27 & 5.24 & 4.94 & 4.63 & 4.34 & 3.81 & 2.76 & 2.00 & 1.45 \\
\hline $\mathrm{Y}-90$ & $2.6 \mathrm{E}-02$ & $2.5 \mathrm{E}-02$ & $2.4 \mathrm{E}-02$ & 2.3E-02 & $2.3 \mathrm{E}-02$ & $2.2 \mathrm{E}-02$ & $1.9 \mathrm{E}-02$ & $1.7 \mathrm{E}-02$ & $1.5 \mathrm{E}-02$ \\
\hline Sr-90 & 98.06 & 97.90 & 95.78 & 93.54 & 91.30 & 87.10 & 77.32 & 68.63 & 60.93 \\
\hline Rh-106 & $4.9 \mathrm{E}-05$ & 4.6E-05 & $2.4 \mathrm{E}-05$ & $1.2 \mathrm{E}-05$ & $6.2 \mathrm{E}-06$ & $1.6 \mathrm{E}-06$ & $5.0 \mathrm{E}-08$ & $1.6 \mathrm{E}-09$ & $5.2 \mathrm{E}-11$ \\
\hline Ag-108m & $1.6 \mathrm{E}-06$ & $1.6 \mathrm{E}-06$ & $1.6 \mathrm{E}-06$ & $1.6 \mathrm{E}-06$ & $1.6 \mathrm{E}-06$ & $1.6 \mathrm{E}-06$ & $1.6 \mathrm{E}-06$ & $1.5 \mathrm{E}-06$ & $1.5 \mathrm{E}-06$ \\
\hline $\mathrm{Sb}-125$ & 6.87 & 6.75 & 5.37 & 4.18 & 3.26 & 1.97 & 0.56 & 0.16 & 0.05 \\
\hline Te-125m & 0.09 & 0.09 & 0.08 & 0.06 & 0.05 & 0.03 & $7.9 \mathrm{E}-03$ & $2.3 \mathrm{E}-03$ & $6.5 \mathrm{E}-04$ \\
\hline Cs-134 & 27.02 & 26.29 & 19.31 & 13.79 & 9.86 & 5.03 & 0.94 & 0.17 & 0.03 \\
\hline Cs-137 & 415.08 & 414.26 & 405.60 & 396.28 & 387.28 & 369.74 & 329.43 & 293.48 & 261.48 \\
\hline Ba-137m & $6.4 \mathrm{E}-05$ & $6.3 \mathrm{E}-05$ & $6.2 \mathrm{E}-05$ & $6.1 \mathrm{E}-05$ & $5.9 \mathrm{E}-05$ & $5.7 \mathrm{E}-05$ & $5.0 \mathrm{E}-05$ & $4.5 \mathrm{E}-05$ & 4.0E-05 \\
\hline Pr-144 & $2.0 \mathrm{E}-03$ & $1.8 \mathrm{E}-03$ & $8.1 \mathrm{E}-04$ & 3.3E-04 & $1.4 \mathrm{E}-04$ & $2.3 \mathrm{E}-05$ & 2.7E-07 & $3.1 \mathrm{E}-09$ & 3.6E-11 \\
\hline Sm-147 & 57.94 & 59.09 & 70.52 & 80.20 & 87.60 & 97.68 & 108.32 & 111.11 & 111.86 \\
\hline Pm-147 & 53.07 & 52.88 & 41.63 & 31.96 & 24.54 & 14.47 & 3.86 & 1.03 & 0.27 \\
\hline Sm-151 & 45.64 & 45.66 & 45.34 & 44.99 & 44.65 & 43.97 & 42.31 & 40.71 & 39.17 \\
\hline Eu-154 & 8.37 & 8.31 & 7.72 & 7.12 & 6.57 & 5.59 & 3.74 & 2.50 & 1.67 \\
\hline Eu-155 & 10.14 & 10.02 & 8.82 & 7.67 & 6.67 & 5.04 & 2.51 & 1.25 & 0.62 \\
\hline
\end{tabular}

\begin{tabular}{|c|c|c|c|c|c|c|c|c|c|}
\hline \multirow[t]{2}{*}{ Isotope } & \multicolumn{9}{|c|}{ Mass per Assembly (g.) } \\
\hline & discharge & 30 days & $1 \mathrm{yr}$. & $2 \mathrm{yr}$ & $3 \mathrm{yr}$. & $5 \mathrm{yr}$. & $10 \mathrm{yr}$. & $15 \mathrm{yr}$. & $20 \mathrm{yr}$. \\
\hline U-234 & 0.10 & 0.10 & 0.11 & 0.16 & 0.23 & 0.30 & 0.44 & 0.77 & 1.08 \\
\hline U-235 & 31.78 & 31.80 & 31.83 & 31.99 & 32.21 & 32.43 & 32.85 & 33.93 & 35.01 \\
\hline U-236 & 11.31 & 11.33 & 11.37 & 11.52 & 11.73 & 11.94 & 12.36 & 13.42 & 14.46 \\
\hline U-237 & 0.19 & $8.9 \mathrm{E}-03$ & $2.5 \mathrm{E}-05$ & $6.2 \mathrm{E}-06$ & $5.9 \mathrm{E}-06$ & $5.6 \mathrm{E}-06$ & $5.1 \mathrm{E}-06$ & 4.0E-06 & $3.2 \mathrm{E}-06$ \\
\hline U-238 & 38106.10 & 38106.10 & 38106.10 & 38106.10 & 38106.10 & 38106.10 & 38106.10 & 38106.10 & 38106.10 \\
\hline Np-237 & 15.53 & 15.72 & 15.73 & 15.75 & 15.80 & 15.86 & 16.02 & 16.64 & 17.49 \\
\hline $\mathrm{Np}-239$ & 12.95 & $1.9 \mathrm{E}-03$ & $1.6 \mathrm{E}-06$ & $1.6 \mathrm{E}-06$ & $1.6 \mathrm{E}-06$ & $1.6 \mathrm{E}-06$ & $1.6 \mathrm{E}-06$ & $1.6 \mathrm{E}-06$ & $1.6 \mathrm{E}-06$ \\
\hline $\mathrm{Pu}-238$ & 7.89 & 8.04 & 8.24 & 8.70 & 8.82 & 8.79 & 8.66 & 8.34 & 8.03 \\
\hline $\mathrm{Pu}-239$ & 7589.82 & 7603.81 & 7603.81 & 7603.81 & 7603.81 & 7603.81 & 7603.81 & 7601.96 & 7601.96 \\
\hline $\mathrm{Pu}-240$ & 2017.40 & 2017.40 & 2017.21 & 2017.21 & 2016.83 & 2016.65 & 2016.27 & 2015.52 & 2014.39 \\
\hline $\mathrm{Pu}-241$ & 209.86 & 209.03 & 207.39 & 200.02 & 190.60 & 181.63 & 164.97 & 129.69 & 101.95 \\
\hline $\mathrm{Pu}-242$ & 24.96 & 24.96 & 24.96 & 24.96 & 24.96 & 24.96 & 24.96 & 24.97 & 24.97 \\
\hline Am-241 & 15.17 & 16.00 & 17.64 & 25.01 & 34.36 & 43.25 & 59.75 & 94.42 & 121.31 \\
\hline Am-242m & 0.58 & 0.58 & 0.58 & 0.58 & 0.58 & 0.58 & 0.57 & 0.56 & 0.55 \\
\hline Am-243 & 1.88 & 1.88 & 1.88 & 1.88 & 1.88 & 1.88 & 1.88 & 1.88 & 1.87 \\
\hline $\mathrm{Cm}-242$ & 1.09 & 0.97 & 0.75 & 0.23 & 0.05 & $1.2 \mathrm{E}-02$ & $1.9 \mathrm{E}-03$ & $1.4 \mathrm{E}-03$ & $1.3 \mathrm{E}-03$ \\
\hline $\mathrm{Cm}-243$ & 0.04 & 0.04 & 0.04 & 0.04 & 0.04 & 0.04 & 0.04 & 0.03 & 0.03 \\
\hline $\mathrm{Cm}-244$ & 0.34 & 0.34 & 0.34 & 0.33 & 0.32 & 0.31 & 0.28 & 0.23 & 0.19 \\
\hline $\mathrm{Cm}-245$ & 0.03 & 0.03 & 0.03 & 0.03 & 0.03 & 0.03 & 0.03 & 0.03 & 0.03 \\
\hline
\end{tabular}




\begin{tabular}{|c|c|c|c|c|c|c|c|c|c|}
\hline \multirow[t]{2}{*}{ Isotope } & \multicolumn{9}{|c|}{ Mass per Assembly (g.) } \\
\hline & discharge & 30 days & $1 \mathrm{yr}$. & $2 \mathrm{yr}$. & $3 \mathrm{yr}$. & $5 \mathrm{yr}$. & $10 \mathrm{yr}$. & $15 \mathrm{yr}$. & $20 \mathrm{yr}$. \\
\hline $\mathrm{Kr}-85$ & 3.82 & 3.80 & 3.76 & 3.59 & 3.36 & 3.15 & 2.77 & 2.00 & 1.45 \\
\hline Y-90 & $1.9 \mathrm{E}-02$ & 1.7E-02 & 1.7E-02 & 1.7E-02 & 1.6E-02 & 1.6E-02 & $1.5 \mathrm{E}-02$ & 1.3E-02 & $1.2 \mathrm{E}-02$ \\
\hline Sr-90 & 67.58 & 7.46 & 67.19 & 65.99 & 64.43 & 62.93 & 60.00 & 53.27 & 47.29 \\
\hline Rh-106 & $5.5 \mathrm{E}-05$ & $5.2 \mathrm{E}-05$ & 4.7E-05 & $2.8 \mathrm{E}-05$ & $1.4 \mathrm{E}-05$ & $7.0 \mathrm{E}-06$ & $1.8 \mathrm{E}-06$ & $5.7 \mathrm{E}-08$ & $1.8 \mathrm{E}-09$ \\
\hline Ag-108m & $1.1 \mathrm{E}-06$ & $1.1 \mathrm{E}-06$ & $1.1 \mathrm{E}-06$ & $1.1 \mathrm{E}-06$ & $1.1 \mathrm{E}-06$ & $1.1 \mathrm{E}-06$ & $1.1 \mathrm{E}-06$ & $1.1 \mathrm{E}-06$ & $1.0 \mathrm{E}-06$ \\
\hline $\mathrm{Sb}-125$ & 5.87 & 5.78 & 5.55 & 4.60 & 3.58 & 2.79 & 1.69 & 0.48 & 0.14 \\
\hline $\mathrm{Te}-125 \mathrm{~m}$ & 0.07 & 0.08 & 0.07 & 0.06 & 0.05 & 0.04 & 0.02 & 0.01 & $1.9 \mathrm{E}-03$ \\
\hline Cs- 134 & 20.71 & 20.14 & 19.06 & 14.79 & 10.57 & 7.55 & 3.86 & 0.72 & 0.13 \\
\hline Cs-137 & 291.08 & 290.55 & 289.44 & 284.44 & 277.95 & 271.59 & 259.31 & 231.03 & 205.83 \\
\hline Ba-137m & $4.5 \mathrm{E}-05$ & 4.4E-05 & 4.4E-05 & 4.4E-05 & 4.3E-05 & 4.2E-05 & $4.0 \mathrm{E}-05$ & $3.5 \mathrm{E}-05$ & $3.1 \mathrm{E}-05$ \\
\hline Pr-144 & 2.3E-03 & 2.2E-03 & $1.9 \mathrm{E}-03$ & $9.5 \mathrm{E}-04$ & $3.9 \mathrm{E}-04$ & $1.6 \mathrm{E}-04$ & $2.7 \mathrm{E}-05$ & $3.1 \mathrm{E}-07$ & $3.7 \mathrm{E}-09$ \\
\hline Sm-147 & 27.15 & 28.17 & 30.17 & 38.31 & 46.90 & 53.50 & 62.44 & 71.87 & 74.36 \\
\hline Pm-147 & 46.81 & 46.92 & 45.12 & 36.98 & 28.39 & 21.80 & 12.85 & 3.43 & 0.92 \\
\hline Sm-151 & 32.13 & 32.18 & 32.14 & 31.95 & 31.70 & 31.46 & 30.98 & 29.81 & 28.68 \\
\hline Eu-154 & 5.54 & 5.50 & 5.43 & 5.11 & 4.71 & 4.35 & 3.70 & 2.47 & 1.65 \\
\hline Eu-155 & 7.90 & 7.81 & 7.64 & 6.87 & 5.98 & 5.20 & 3.93 & 1.95 & 0.97 \\
\hline
\end{tabular}

\begin{tabular}{|c|c|c|c|c|c|c|c|c|c|}
\hline \multirow[t]{2}{*}{ Isotope } & \multicolumn{9}{|c|}{ Mass per Assembly (g.) } \\
\hline & discharge & 30 days & $1 \mathrm{yr}$. & $2 \mathrm{yr}$. & $3 \mathrm{yr}$. & $5 \mathrm{yr}$. & $10 \mathrm{yr}$. & $15 \mathrm{yr}$. & $20 \mathrm{yr}$. \\
\hline U-234 & 0.11 & 0.12 & 0.13 & 0.19 & 0.27 & 0.35 & 0.53 & 0.95 & 1.34 \\
\hline $\mathrm{U}-235$ & 23.17 & 23.19 & 23.23 & 23.39 & 23.62 & 23.83 & 24.28 & 25.39 & 26.50 \\
\hline U-236 & 10.65 & 10.67 & 10.72 & 10.93 & 11.22 & 11.50 & 12.06 & 13.46 & 14.87 \\
\hline U-237 & 0.19 & $8.75 \mathrm{E}-03$ & $2.84 \mathrm{E}-05$ & $9.69 \mathrm{E}-06$ & $9.22 \mathrm{E}-06$ & $8.75 \mathrm{E}-06$ & $8.04 \mathrm{E}-06$ & $6.26 \mathrm{E}-06$ & $4.96 \mathrm{E}-06$ \\
\hline U-238 & 31310.54 & 31310.54 & 31310.54 & 31310.54 & 31310.54 & 31310.54 & 31310.54 & 31310.54 & 31310.54 \\
\hline Np-237 & 13.12 & 13.31 & 13.32 & 13.36 & 13.43 & 13.52 & 13.77 & 14.70 & 16.03 \\
\hline Np-239 & 13.26 & $2.01 \mathrm{E}-03$ & $3.31 \mathrm{E}-06$ & $3.31 \mathrm{E}-06$ & $3.31 \mathrm{E}-06$ & $3.31 \mathrm{E}-06$ & $3.31 \mathrm{E}-06$ & $3.31 \mathrm{E}-06$ & $3.31 \mathrm{E}-06$ \\
\hline $\mathrm{Pu}-238$ & 9.31 & 9.57 & 9.94 & 10.78 & 11.02 & 10.99 & 10.85 & 10.45 & 10.06 \\
\hline $\mathrm{Pu}-239$ & 7835.27 & 7848.22 & 7848.22 & 7848.22 & 7848.22 & 7848.22 & 7848.22 & 7848.22 & 7845.74 \\
\hline $\mathrm{Pu}-240$ & 2698.41 & 2698.41 & 2698.23 & 2698.23 & 2697.88 & 2697.71 & 2697.18 & 2695.79 & 2694.57 \\
\hline $\mathrm{Pu}-241$ & 328.56 & 327.27 & 324.70 & 313.12 & 298.42 & 284.38 & 258.28 & 203.03 & 159.61 \\
\hline $\mathrm{Pu}-242$ & 45.14 & 45.14 & 45.14 & 45.14 & 45.14 & 45.14 & 45.14 & 45.14 & 45.14 \\
\hline Am-241 & 21.19 & 22.49 & 25.06 & 36.59 & 51.24 & 65.16 & 91.03 & 145.30 & 187.39 \\
\hline Am-242m & 0.92 & 0.92 & 0.92 & 0.91 & 0.91 & 0.91 & 0.90 & 0.87 & 0.85 \\
\hline Am-243 & 3.88 & 3.88 & 3.88 & 3.88 & 3.88 & 3.88 & 3.88 & 3.88 & 3.88 \\
\hline $\mathrm{Cm}-242$ & 1.93 & 1.71 & 1.32 & 0.41 & 0.09 & 0.02 & $2.96 \mathrm{E}-03$ & $2.13 \mathrm{E}-03$ & $2.13 \mathrm{E}-03$ \\
\hline $\mathrm{Cm}-243$ & 0.09 & 0.09 & 0.09 & 0.09 & 0.09 & 0.09 & 0.08 & 0.07 & 0.07 \\
\hline $\mathrm{Cm}-244$ & 0.85 & 0.85 & 0.84 & 0.82 & 0.79 & 0.76 & 0.70 & 0.58 & 0.48 \\
\hline $\mathrm{Cm}-245$ & 0.08 & 0.08 & 0.08 & 0.08 & 0.08 & 0.08 & 0.08 & 0.08 & 0.08 \\
\hline
\end{tabular}




\begin{tabular}{|c|c|c|c|c|c|c|c|c|c|}
\hline \multirow[t]{2}{*}{ Isotope } & \multicolumn{9}{|c|}{ Mass per Assembly (g.) } \\
\hline & discharge & 30 days & $1 \mathrm{yr}$. & 2 yr. & $3 \mathrm{yr}$. & $5 \mathrm{yr}$. & $10 \mathrm{yr}$. & $15 \mathrm{yr}$. & $20 \mathrm{yr}$. \\
\hline $\mathrm{Kr}-85$ & 4.48 & 4.46 & 4.41 & 4.20 & 3.94 & 3.69 & 3.24 & 2.34 & 1.70 \\
\hline Y-90 & $2.2 \mathrm{E}-02$ & $2.0 \mathrm{E}-02$ & $2.0 \mathrm{E}-02$ & $1.9 \mathrm{E}-02$ & $1.9 \mathrm{E}-02$ & $1.9 \mathrm{E}-02$ & $1.8 \mathrm{E}-02$ & $1.5 \mathrm{E}-02$ & $1.4 \mathrm{E}-02$ \\
\hline $\operatorname{Sr}-90$ & 78.79 & 78.64 & 78.33 & 76.96 & 75.14 & 73.38 & 69.96 & 62.10 & 55.14 \\
\hline Rh-106 & $6.7 \mathrm{E}-05$ & $6.3 \mathrm{E}-05$ & $5.7 \mathrm{E}-05$ & $3.3 \mathrm{E}-05$ & $1.7 \mathrm{E}-05$ & $8.5 \mathrm{E}-06$ & $2.1 \mathrm{E}-06$ & $6.9 \mathrm{E}-08$ & $2.2 \mathrm{E}-09$ \\
\hline Ag- $108 \mathrm{~m}$ & $1.4 \mathrm{E}-06$ & $1.3 \mathrm{E}-06$ & $1.3 \mathrm{E}-06$ & $1.3 \mathrm{E}-06$ & $1.3 \mathrm{E}-06$ & $1.3 \mathrm{E}-06$ & $1.3 \mathrm{E}-06$ & $1.3 \mathrm{E}-06$ & $1.3 \mathrm{E}-06$ \\
\hline $\mathrm{Sb}-125$ & 6.73 & 6.62 & 6.36 & 5.26 & 4.10 & 3.19 & 1.94 & 0.56 & 0.15 \\
\hline $\mathrm{Te}-125 \mathrm{~m}$ & 0.08 & 0.08 & 0.08 & 0.07 & 0.06 & 0.05 & 0.02 & 0.01 & $2.2 \mathrm{E}-03$ \\
\hline Cs-134 & 25.47 & 24.79 & 23.45 & 18.20 & 13.00 & 9.29 & 4.74 & 0.89 & 0.17 \\
\hline Cs-137 & 344.86 & 344.21 & 342.91 & 337.01 & 329.29 & 321.79 & 307.24 & 273.72 & 243.86 \\
\hline Ba-137m & $5.3 \mathrm{E}-05$ & 5.3E-05 & 5.2E-05 & 5.2E-05 & $5.1 \mathrm{E}-05$ & $5.0 \mathrm{E}-05$ & 4.7E-05 & $4.1 \mathrm{E}-05$ & $3.8 \mathrm{E}-05$ \\
\hline Pr-144 & $2.7 \mathrm{E}-03$ & $2.6 \mathrm{E}-03$ & 2.2E- 03 & $1.1 \mathrm{E}-03$ & 4.6E-04 & $1.9 \mathrm{E}-04$ & $3.2 \mathrm{E}-05$ & $3.8 \mathrm{E}-07$ & $4.4 \mathrm{E}-09$ \\
\hline Sm-147 & 31.51 & 32.71 & 35.03 & 44.54 & 54.55 & 62.23 & 72.67 & 83.66 & 86.61 \\
\hline $\mathrm{Pm}-147$ & 54.57 & 54.70 & 52.61 & 43.12 & 33.11 & 25.42 & 14.99 & 4.00 & 1.06 \\
\hline $\mathrm{Sm}-151$ & 37.66 & 37.71 & 37.66 & 37.43 & 37.15 & 36.87 & 36.30 & 34.93 & 33.62 \\
\hline Eu-154 & 6.73 & 6.68 & 6.58 & 6.21 & 5.72 & 5.28 & 4.49 & 3.00 & 2.01 \\
\hline Eu-155 & 9.43 & 9.33 & 9.11 & 8.20 & 7.13 & 6.19 & 4.69 & 2.33 & 1.16 \\
\hline
\end{tabular}

4.5 Construction

\subsubsection{General Construction Requirements}

Preliminary estimates of construction requirements for the ABR plant are summarized in Table 26. Steel usage includes structural steel, component steel, furnishings, support systems such as fire protection and railroads, fences, and steel used in the HVAC and electrical systems. Water requirements include compaction of fill, dust control, fire protection, sanitary facilities, production of concrete, and other construction-related activities. See the discussion of Table 26 in Appendix A for further details regarding the basis for the estimates presented in the table.

\subsubsection{Construction Land Requirements}

Table 27 outlines the estimated land use needed to build an ABR. Details of how these estimates were obtained are given in Appendix A. Once an accident analysis of the ABR is completed and radioactivity release values are available, the total site area will be adjusted consistent with regulatory requirements governing releases at the site boundary. 


\subsubsection{Construction Wastes}

It is assumed that no low-level or mixed low-level radioactive wastes will be generated during the construction of the ABR plant. The estimated quantities of all hazardous and non-hazardous construction wastes are listed in Table 28. These wastes are assumed to scale with plant size. The information used to generate these waste estimates is provided in the discussion of Table 28 in Appendix A and in the spreadsheet tables listed in Appendix B.

\begin{tabular}{|c|c|c|c|}
\hline \multicolumn{4}{|c|}{$\begin{array}{r}\text { Table 26. Preliminary Construction Requirements for the } A \\
\text { ABR Power Capacity }\end{array}$} \\
\hline & 250 MWth & 1000 MWth & 2000 MWth \\
\hline $\begin{array}{l}\text { Construction Period (including } \\
\text { cold start-up) }\end{array}$ & 5 years & 5.5 years & 6 years \\
\hline \multicolumn{4}{|l|}{ Construction Employment } \\
\hline Total worker years & 2700 & 7000 & 11400 \\
\hline Peak workers $\left(4^{\text {th }}\right.$ or $5 t^{\mathrm{h}}$ year $)$ & 780 & 2050 & 3330 \\
\hline \multicolumn{4}{|c|}{ Materials/Resources Consumed During Construction Period } \\
\hline $\begin{array}{l}\text { Electrical Power required } \\
\text { (Peak) }\end{array}$ & $9 \mathrm{MWe}$ & $23 \mathrm{MWe}$ & $38 \mathrm{MWe}$ \\
\hline $\begin{array}{l}\text { Power available from back-up } \\
\text { generators }\end{array}$ & $2 \mathrm{MWe}$ & $6 \mathrm{MWe}$ & $12 \mathrm{MWe}$ \\
\hline Back-up generators, fuel type. & \multicolumn{3}{|c|}{ Internal combustion, diesel or natural gas } \\
\hline Concrete $\left(\mathrm{yd}^{3}\right)$ & 76,000 & 200,000 & 325,000 \\
\hline Steel (tons) & 9,900 & 24,700 & 39,200 \\
\hline Liquid fuel (gal.) & 60,000 & 144,00 & 243,000 \\
\hline Lube oil (gal.) & 700 & 1,700 & 2,900 \\
\hline Water (gal/day, max.) & 20,000 & 51,000 & 83,000 \\
\hline
\end{tabular}

\begin{tabular}{|l|c|c|c|}
\hline \multicolumn{4}{|c|}{ Table 27. Estimated ABR Construction Land Requirements } \\
\hline \multirow{3}{*}{\multicolumn{1}{c}{ Land Use }} & \multicolumn{3}{c|}{ ABR Power Capacity } \\
\cline { 2 - 4 } & 250 MWth & 1000 MWth & 2000 MWth \\
\cline { 2 - 4 } & Land Area (acres) & Land Area (acres) & Land Area (acres) \\
\hline Total Permanent Site & 1100 & 1400 & 1640 \\
\hline Facilities & 80 & 100 & 120 \\
\hline Plant & 3 & 4 & 5 \\
\hline Temporary Laydown Area & 60 & 160 & 250 \\
\hline Temporary Parking Lots & 5 & 12 & 20 \\
\hline Permanent Parking Lots & 2 & 2 & 3 \\
\hline
\end{tabular}




\begin{tabular}{|c|c|c|c|c|c|c|}
\hline Waste & & I ianid (all) & & & Solid & \\
\hline vraste & & & & & ONu & \\
\hline & $\begin{array}{c}250 \\
\text { MWth }\end{array}$ & $\begin{array}{l}1000 \\
\text { MWth }\end{array}$ & $\begin{array}{c}2000 \\
\text { MWth }\end{array}$ & 250 MWth & 1000 MWth & 2000 MWth \\
\hline Hazardous & 7,200 & 21,000 & 37,200 & $1.4 \mathrm{yd}^{3}$ & $4.1 \mathrm{yd}^{3}$ & $7.2 \mathrm{yd}^{3}$ \\
\hline $\begin{array}{l}\text { Non-hazardous } \\
\text { (sanitary): }\end{array}$ & - & - & - & 440 tons & 1,150 tons & 1,870 tons \\
\hline $\begin{array}{ll}\text { - } & \text { Liquid } \\
\text { waste } \\
\text { processed } \\
\text { on site }\end{array}$ & $23,000,000$ & $61,000,000$ & $99,000,000$ & - & - & - \\
\hline $\begin{array}{ll}\text { - } & \begin{array}{l}\text { Portable } \\
\text { toilets }\end{array}\end{array}$ & 196,000 & 518,000 & 841,000 & - & - & - \\
\hline $\begin{array}{l}\text { Non-hazardous } \\
\text { (other) }\end{array}$ & 82,000 & 217,000 & 352,000 & $32,400 \mathrm{yd}^{3}$ & $85,600 \mathrm{yd}^{3}$ & $139,000 \mathrm{yd}^{3}$ \\
\hline
\end{tabular}


References

[Cahalan, 1990] Cahalan, J. et al., "Performance of Metal and Oxide Fuels during Accidents in a Large Liquid Metal Cooled Reactor", Proc. 1990 Intl. Fast Reactor Safety Mtg., Snowbird UT, Vol. IV, p. 73, August, 1990.

[Chang, 2006] Chang, Y. I. et al., "Advanced Burner Test Reactor Preconceptual Design Report,” ANL-ABR-1 (ANL-AFCI-173), September 5, 2006.

[Caterpillar, 1990] Caterpillar Performance Handbook, $21^{\text {st }}$ edition.

[Cabell, 1980] Cabell, C. P., A Summary Description of the Fast Flux Test Facility, HEDL-400, Richland, Wash., 1980.

[CRBRP, 1982] Clinch River Breeder Reactor Preliminary Safety Analysis Report, Amendment 70, Project Management Corporation, 1982.

[CRBRP, 1977] Clinch River Breeder Reactor Plant Environmental Report, Vols. 2 and 3, Project Management Corporation, 1977.

[CRBRP, 1974] Clinch River Breeder Reactor Plant Reference Design Report, Vol. I, Westinghouse Electric Corporation, June 1974.

[Cutforth, 1971] Cutforth, D. C. and W. H. Perry, "Purity of EBR-II Primary Cover Gas," ANL/EBR-052, November 1971.

[Flores, 2007] Flores, Oscar E., San Onofre Nuclear Generating Station, Southern California Edison, private communication.

[IAEA, 2007] "Power Reactor Information System: United States of America," IAEA Power Reactor Information System home page

[http://www.iaea.org/programmes/a2/index.html].

[Kim, 2006a] Kim, T. K. and W. S. Yang, Argonne National Laboratory, private communication, December 20, 2006.

[Kim, 2006b] Kim, T. K., W. S. Yang, and R. N. Hill, Argonne National Laboratory, private communication, September 1, 2006.

[Kim, 2007a] Kim, T. K. and W. S. Yang, Argonne National Laboratory, private communication, June 2007.

[Kim, 2007b] Kim, T. K. and W. S. Yang, Argonne National Laboratory, private communication, June 2007.

[Lawson, 2007] Lawson, J., Spallation Neutron Source, private communication. 
[Lomperski, 2007] Lomperski, S. W., Argonne National Laboratory, private communication.

[MDNR, 2006] Missouri Department of Natural Resources website, December 18, 2006 [http://www.dnr.mo.gov/env/swmp/pubs-reports/Table101.htm].

[Mirant, 2007] "Zeeland Generating Plant," Mirant Corporation web site [http://www.mirant.com/our_business/where_we_work/zeeland.htm].

[NEF, 2005] National Enrichment Facility Safety Analysis Report, Rev. 7, Louisiana Energy Services, June 2005 [http://www.nrc.gov/materials/fuel-cycle-fac/licapp-envirrpts.html].

[Perry, 1997] Perry, R.H., D. W. Green, and J. O. Maloney, Perry's Chemical Engineers Handbook, McGraw-Hill, 1997, p. 27-9.

[PSAI, 2006] Portable Sanitation Association International, September 24, 2006 [http: //www.americanrestroom.org/contacts/PSAI\%20Extended\%20Chart\%20w_pics.pdf]

[Royl, 1990] Royl, P. et al., "Influence of Metal and Oxide Fuel Behavior on the ULOF Accident in 3500MWth Heterogeneous LMR Cores and Comparison with Other Large Cores," Proc. 1990 Intl. Fast Reactor Safety Mtg., Snowbird UT, Vol. IV, p. 83, August, 1990.

[Sienicki, 2007] Sienicki, J. and A. Moisseytsev, Argonne National Laboratory, private communication.

[Smith, 2002] Smith, D., "Adequate Cooling of Generators is Essential", Power Engineering, Vol. 106, part 9, pp. 42-47, September 2002.

[http://pepei.pennnet.com/articles/article_display.cfm?article_id=154893]

[Speranza, 2005] Speranza, J., "Continuous hydrogen replacement technique offers improved power plant electric generator efficiency and longevity," Technical Update from Proton Energy, January 2005.

[http://72.14.253.104/search?q=cache:rwJY2mqFdAAJ:www.protonenergy.com/data/Un sorted/H2Replen_v3-17411.pdf+\%22Mirant-

Zeeland+improves + operational+efficiency $\% 22 \&$ hl=en\&ct=clnk\&cd=1\&gl=us]

[Tawney, 2003] Tawney, R., Z. Khan, and J. Zachary, "Economic and Performance Evaluation of Heat Sink Options in Combined Cycle Applications," Proceedings of Turbo Expo: ASME/IGTI Turbo Expo, June 16-19, 2003.

[USDOE, 1988] Phase IX Update (1987) report for the Energy Economic Data Base Program, EEDB-IX, U.S. Department of Energy, DOE/NE-0091, 1988. 
[USEPA, 1999] U.S. Environmental Protection Agency, Biosolids Generation, Use, and Disposal in The United States, EPA530-R-99-009, September 1999 [http://www.epa.gov /epaoswer/non-hw/compost/biosolid.pdf].

[USNRC, 2005] Environmental Impact Statement for the Proposed National Enrichment Facility in Lea County, New Mexico, NUREG-1790, June 2005 [http://www.nrc.gov/ reading-rm/doc-collections/nuregs/staff/sr1790/ch4-10.pdf].

[USNRC, 2006] Code of Federal Regulations, Title 10, Part 20, Subpart C (sections 1201-1208), Nuclear Regulatory Commission

[http://www.access.gpo.gov/nara/cfr/waisidx_06/10cfr20_06.html]. 


\section{Appendix A: Bases for Data Presented}

As mentioned in Sec. 1, the datacall information presented in this report was derived from a number of information sources. Table A.1 identifies these sources with the particular data parameters to which each source contributed.

\begin{tabular}{|c|c|}
\hline \multicolumn{2}{|c|}{ Table A.1. Data Sources for Various Parameters } \\
\hline Data Source & Parameters \\
\hline $\begin{array}{l}\text { Clinch River Breeder Reactor Plant Environmental } \\
\text { Report [CRBRP, 1977] }\end{array}$ & $\begin{array}{l}\text { Employment estimates (construction and } \\
\text { operations), liquid radioactive waste effluent } \\
\text { activities, radionuclide gaseous emissions, } \\
\text { radioactive and hazardous wastes volumes, sanitary } \\
\text { liquid waste, plant power consumption, fossil fuel } \\
\text { usage (construction and operations), chemical usage } \\
\text { (sodium hypochlorite, sulfuric acid, sodium } \\
\text { hydroxide), water usage (construction and } \\
\text { operations), quantities of hazardous air pollutants, } \\
\text { concrete volume for construction, land } \\
\text { requirements, sanitary liquid wastes, plant electrical } \\
\text { requirements }\end{array}$ \\
\hline $\begin{array}{l}\text { Clinch River Breeder Reactor Preliminary Safety } \\
\text { Analysis Report [CRBRP, 1982] }\end{array}$ & Employment estimates \\
\hline $\begin{array}{l}\text { National Enrichment Facility Safety Analysis } \\
\text { Report [NEF, 2005] and Environmental Impact } \\
\text { Statement [USNRC, 2005] }\end{array}$ & Construction hazardous wastes \\
\hline $\begin{array}{l}\text { Missouri Department of Natural Resources [MDNR, } \\
2006 \text { ] }\end{array}$ & Construction solid sanitary wastes \\
\hline Energy Economic Data Base [USDOE , 1988] & $\begin{array}{l}\text { Construction sanitary and non-hazardous wastes, } \\
\text { steel usage }\end{array}$ \\
\hline $\begin{array}{l}\text { Caterpillar Performance Handbook [Caterpillar } \\
\text { 1990] }\end{array}$ & Construction liquid fuel and lube oil. \\
\hline ABTR Preconceptual Design Report [Chang, 2006] & $\begin{array}{l}\text { Plant power consumption, plant layout and building } \\
\text { dimensions, inert gases used, plant electrical } \\
\text { requirements, operations fossil fuel usage, process } \\
\text { gases }\end{array}$ \\
\hline $\begin{array}{l}\text { Fuel cycle analyses performed for the ABR [Kim, } \\
\text { 2006a], [Kim, 2006b], [Kim, 2007a], [Kim, 2007b] }\end{array}$ & $\begin{array}{l}\text { Fissile inventory, spent fuel discharge, decay heat } \\
\text { and isotopic masses of spent fuel. }\end{array}$ \\
\hline Spallation Neutron Source [Lawson, 2007] & Construction electrical requirements \\
\hline $\begin{array}{l}\text { San Onofre Nuclear Generating Station [Flores, } \\
\text { 2007] }\end{array}$ & $\begin{array}{l}\text { Process gases, chemical usage (hydrazine, } \\
\text { monoethanalomine }\end{array}$ \\
\hline $\begin{array}{l}\text { Zeeland Generating Plant [Mirant, 2007] and } \\
\text { [Speranza, 2005] }\end{array}$ & Hydrogen usage \\
\hline $\begin{array}{l}\text { Portable Sanitation Association International [PSAI, } \\
\text { 2006] }\end{array}$ & Construction liquid sanitary wastes \\
\hline $\begin{array}{l}\text { Power Engineering article on cooling of generators } \\
\text { [Smith, 2002] }\end{array}$ & Hydrogen usage \\
\hline
\end{tabular}


As indicated in Sec. 3.1, values for some operational parameters and some construction parameters are dependent upon reactor power, but not necessarily by a simple linear dependence. Table A.2 summarizes the various techniques used to adjust parameters for reactor power. Details of these adjustments are discussed in the explanations below of the calculations used for the data presented in each table.

\begin{tabular}{|c|c|}
\hline \multicolumn{2}{|c|}{ Table A.2. Approaches to Scaling for Reactor Power for Various Parameters } \\
\hline Parameters & Scaling Approach \\
\hline $\begin{array}{l}\text { Fissile inventory, spent fuel discharge, } \\
\text { spent fuel physics data }\end{array}$ & Fuel cycle analysis of candidate core designs \\
\hline Building and structure dimensions & Sized to fit equipment \\
\hline Low-level liquid waste & Linear with power \\
\hline Low-level solid waste & Linear with power for solidified liquid radwaste \\
\hline Mixed low-level solid waste & Linear with power for most components \\
\hline Hazardous liquid and solid wastes & Linear with power \\
\hline Sanitary liquid and solid wastes & Linear with power \\
\hline Solid non-hazardous waste & Linear with power \\
\hline Electrical demand for operations & $\begin{array}{l}\text { Linear scaling with power for sodium and water } \\
\text { pumps, } \mathrm{CO}_{2} \text { compressors (Brayton cycle } \\
\text { option), feedwater and condensate pumps } \\
\text { (Rankine cycle option) }\end{array}$ \\
\hline Emergeny generator fossil fuel use & Linear with generator capacity \\
\hline Grounds maintenance fossil fuel use & Scaled to facilities areas \\
\hline Process gases & Linear with power \\
\hline Process chemicals & Linear with power \\
\hline Operations employment & $\begin{array}{l}88 \% \text { of CRBRP for } 250 \text { MWth, } 112 \% \text { for } 2000 \\
\text { MWth }\end{array}$ \\
\hline Water usage & Linear with power \\
\hline $\begin{array}{l}\text { Activity of liquid waste effluent and } \\
\text { gaseous radionuclide emissions }\end{array}$ & Linear with power \\
\hline Hazardous air pollutants & Linear with power \\
\hline Construction time & Data on construction of existing plants \\
\hline Construction employment & $\left(\mathrm{P}_{\mathrm{ABR}} / \mathrm{P}_{\mathrm{CRBR}}\right)^{0.7}$ (take $\mathrm{P}_{\mathrm{CRBR}}$ to be $\left.1000 \mathrm{MWth}\right)$ \\
\hline Construction electrical power & Linear scaling \\
\hline Concrete & $\left(\mathrm{P}_{\mathrm{ABR}} / \mathrm{P}_{\mathrm{CRBR}}\right)^{0.7}$ (take $\mathrm{P}_{\mathrm{CRBR}}$ to be $\left.1000 \mathrm{MWth}\right)$ \\
\hline Steel & Primarily scaling by $\left(\mathrm{P}_{\mathrm{ABR}} / \mathrm{P}_{\mathrm{PWR}}\right)^{0.7}$ \\
\hline Construction liquid fuel and lube oil & $\begin{array}{l}\text { Proportional to land requirements and concrete } \\
\text { volume }\end{array}$ \\
\hline Construction water consumption & $\left(\mathrm{P}_{\mathrm{ABR}} / \mathrm{P}_{\mathrm{CRBR}}\right)^{0.7}$ (take $\mathrm{P}_{\mathrm{CRBR}}$ to be $\left.1000 \mathrm{MWth}\right)$ \\
\hline Land requirements & $\begin{array}{l}80 \% \text { of CRBRP for } 250 \text { MWth, } 120 \% \text { for } 2000 \\
\text { MWth }\end{array}$ \\
\hline Construction waste & Primarily scaling by $\left(\mathrm{P}_{\mathrm{ABR}} / \mathrm{P}_{\mathrm{PWR}}\right)^{0.7}$ \\
\hline
\end{tabular}




\section{Table 1 (fissile inventory):}

The maximum inventory of core fissile material is in the startup cores. Isotopes included are U-235, Pu-239, Pu-241, and Am-242m. Inventories for the $2000 \mathrm{MWth}$ core designs include an entire batch of discharged fuel assemblies in the in-vessel storage. BOEC inventories discussed in [Kim, 2006b] for a $250 \mathrm{MWth}$ ABR and in [Kim, 2007b] for a 1000 MWth ABR do not include in-vessel storage; therefore, the fissile discharge from a single batch (the annual discharge for the $1000 \mathrm{MWth}$ ABR; one-sixth of the annual discharge for the $250 \mathrm{MWth} A B R$, since fuel is discharged from the 250 MWth design every two months) was added to the BOEC inventory in order to make a consistent comparison with the inventories for the 2000 MWth plant.

In-vessel 2000 MWth metal fuel fissile inventory $=28.3+4536.5+42.6+0.1$

$$
\approx 4600 \mathrm{~kg} \text {. }
$$

(from Table 4.3, [Kim, 2006a])

$$
\begin{aligned}
\text { In-vessel 1000 MWth metal fuel fissile inventory }= & (17.4+1824.1+12.8)+ \\
& (2.6+396.3+5.8) \\
& \approx 2260 \mathrm{~kg}
\end{aligned}
$$

(from [Kim, 2007b])

$$
\begin{aligned}
\text { In-vessel 250 MWth metal fuel fissile inventory }= & (1.9+446.5+66.7+0.9)+ \\
& (0.7+173.6+25.5+0.7) / 6 \\
\approx & 550 \mathrm{~kg}
\end{aligned}
$$

(from Table 6.7, [Kim, 2006b])

The 2000 MWth oxide core discussed in [Kim, 2006a] has a higher TRU conversion ratio than the 2000 MWth metal core, and so, in order to estimate fissile inventory for the oxide core on the same basis as for the metal core, the oxide core must be adjusted as follows to achieve the same TRU conversion ratio as the metal core.

For a 2000 MWth oxide core,

oxide fissile discharge rate $=$ oxide fissile charge rate oxide fissile material consumption

If the oxide core achieves the same conversion ratio as the metal core, then

oxide core fissile material consumption $=$ metal core fissile material consumption

$=$ metal startup core fissile charge metal startup core fissile discharge $=(9.5+1314.3+8.7)-(4.7+943+18.8+0.1)$

(from Table 3.4, [Kim, 2006a])

$$
\approx 370 \mathrm{~kg} . / \mathrm{yr} \text {. }
$$

The oxide fissile charge rate is adjusted for the TRU conversion ratio as follows: 
(from Table 3.4, [Kim, 2006a])

oxide adj. fissile charge rate $=$ (oxide TRU charge rate at the orig. conv. ratio) $\mathrm{x}$ (metal fissile charge rate)/(metal TRU charge rate)

$=(1468.9)(9.5+1314.3+8.7) / 1422.1)$

$\approx 1380 \mathrm{~kg} . / \mathrm{yr}$.

The adjusted oxide fissile discharge rate is then

oxide adjusted fissile discharge rate $\approx 1380-370 \approx 1010 \mathrm{~kg} . / \mathrm{yr}$.

The adjusted BOEC oxide core fissile inventory, assuming that replacing the entire core requires three batches, can be found from

adj. oxide core fissile inv. $=($ adj. oxide core heavy metal $(\mathrm{HM})$ inv. $) \mathrm{x}$ (metal core fissile inventory)/(metal core HM inv.)

adj. oxide core HM inv. = (no. of batches $) \times($ (total metal HM charge $) /$ (total metal TRU charge))x(orig. oxide TRU charge) (oxide HM consumption)

$$
\begin{aligned}
& =(3) \times((6233.0) /(1422.1)) *(1468.9)-(4884.9-4209.4) \\
& \approx 18,640 \mathrm{~kg} .
\end{aligned}
$$

(from Table 3.4, [Kim, 2006a])

The metal core fissile inventory is the total BOEC fissile inventory minus the in-vessel storage, or

metal core fissile inventory $=\mathrm{BOEC}$ total fissile inventory

$$
\begin{aligned}
& - \text { BOEC in-vessel storage fissile inventory } \\
= & (28.3-4.7)+(4536.5-948.8)+(42.6-17.3)+0.1 \\
\approx & 3700 \mathrm{~kg}
\end{aligned}
$$

(from Table 4.3, [Kim, 2006a])

Therefore,

adj. oxide core fissile inv. $=(18,640) *(3700) /(2657.9+5848.2+9522.7)$

$$
\approx 3760 \mathrm{~kg} \text {. }
$$

(from Table 4.3, [Kim, 2006a])

The in-vessel fissile inventory for the 2000 MWth oxide core is therefore

In-vessel 2000 MWth oxide fuel fissile inventory $=$ core fissile inv. +

1 cycle discharge

$\approx 3760+(1010) / 1$

$=4770 \mathrm{~kg}$.

Making similar adjustments to the 250 MWth oxide core, 
(from Table 6.7, [Kim, 2006b])

oxide core fissile material consumption $=$ metal core fissile material consumption

$=$ metal startup core fissile charge metal startup core fissile discharge

$=(1.0+222.6+33.8)-$ $(0.7+173.6+25.5+0.7)$

$\approx 57 \mathrm{~kg} . / \mathrm{yr}$.

The oxide fissile charge rate is then adjusted for the TRU conversion ratio as

oxide adj. fissile charge rate $=($ oxide TRU charge rate at the orig. conv. ratio $) \mathrm{x}$ (metal fissile charge rate)/(metal TRU charge rate) $=(449.2)(1.0+222.6+33.8) / 431.0)$ $\approx 268 \mathrm{~kg} . / \mathrm{yr}$.

(from Tables 6.7 and 6.8, [Kim, 2006b])

The adjusted oxide fissile discharge rate is then

oxide adjusted fissile discharge rate $\approx 268-57 \approx 211 \mathrm{~kg}$. $/ \mathrm{yr}$.

The adjusted BOEC oxide core fissile inventory, assuming that the average fuel residence time is 2.25 batches, can be found from

adj. oxide core fissile inv. $=($ adj. oxide core heavy metal $(\mathrm{HM})$ inv. $) \mathrm{x}$ (metal core fissile inventory)/(metal core HM inv.)

adj. oxide core $\mathrm{HM}$ inv. $=($ no. of batches $) \times($ (total metal $\mathrm{HM}$ charge $) /$ (total metal TRU charge))x(orig. oxide TRU charge) (oxide HM consumption)

$=(2.25) \times((932.7) /(431.0)) *(449.2)-(1007.8-923.5)$

$\approx 2,103 \mathrm{~kg}$.

(from Tables 6.7 and 6.8, [Kim, 2006b])

The metal core fissile inventory is the BOEC fissile inventory, or

BOEC core fissile inventory $=1.9+446.5+66.7+0.9 \approx 516 \mathrm{~kg}$.

(from Table 6.7, [Kim, 2006b])

Therefore,

adj. oxide core fissile inv. $=(2,103) *(516) /(1984.6)$

$$
\approx 545 \mathrm{~kg} \text {. }
$$

(from Table 6.7, [Kim, 2006b])

The in-vessel fissile inventory for the 250 MWth oxide core is therefore 
In-vessel 250 MWth oxide fuel fissile inventory = core fis. inv. +1 cycle discharge

$\approx 545+(211) *(2 / 12 \mathrm{yr}$. $)$

$=580 \mathrm{~kg}$.

The 1000 MWth oxide and metal cores addressed in [Kim, 2007b] have very similar conversion ratios. Therefore, the in-vessel fissile inventory for the $1000 \mathrm{MWth}$ oxide core is calculated directly from the inventory and mass flow values given in [Kim, 2007b], or

$$
\begin{aligned}
\text { In-vessel } 1000 \text { MWth oxide fuel fissile inventory }= & \text { core fis. inv. }+1 \text { cycle } \\
& \text { discharge } \\
= & (16.2+2137.6+21.4)+ \\
& (1.8+362.8+8.6) \\
\approx & 2550 \mathrm{~kg} .
\end{aligned}
$$

Assuming the startup fuel is stored on-site indefinitely, the maximum fissile inventory at the plant can be estimated from the annual fissile discharge inventory over the sixty years of reactor operation, plus the beginning of equilibrium cycle (BOEC) core fissile inventory (total metal fuel fissile inventory, minus the spent fuel fissile inventory in the in-vessel storage). For a 2000 MWth metal core operating sixty years and discharging fuel annually,

Total discharge fissile inventory $=(60-($ cycle length $($ mo. $)) / 12)($ discharge inv. rate $)$

$$
=(60-(12 / 12) \text { yrs. })(4.7+943.0+18.8+0.1 \mathrm{~kg} / \mathrm{yr})
$$

(from Table 3.4, [Kim, 2006a])

BOEC core fissile inventory $=$ BOEC total fissile inventory

- BOEC in-vessel storage fissile inventory

$$
\begin{aligned}
& =(28.3-4.7)+(4536.5-948.8)+(42.6-17.3)+0.1 \\
& \approx 3600 \mathrm{~kg}
\end{aligned}
$$

(from Table 4.3, [Kim, 2006a])

Maximum 2000 MWth metal fissile inventory = Total discharge fissile inv.

+ BOEC core fissile inv.

$$
\begin{aligned}
& =57,000+3600 \\
& =60,600 \mathrm{~kg} .
\end{aligned}
$$

For a $1000 \mathrm{MWth}$ metal core operating sixty years and discharging fuel annually,

Total discharge fissile inventory $=(60-($ cycle length $($ mo. $)) / 12)($ discharge inv. rate $)$

$$
\begin{aligned}
& =(60-(12 / 12) \mathrm{yrs} .)(2.6+396.3+5.8 \mathrm{~kg} / \mathrm{yr}) \\
& \approx 23,900 \mathrm{~kg} .
\end{aligned}
$$

(from [Kim, 2007b]) 
BOEC core fissile inventory $=17.4+1824.1+12.8 \approx 1850 \mathrm{~kg}$.

(from [Kim, 2007b])

Maximum 1000 MWth metal fissile inventory $\approx 23,900+1850 \approx 25,700 \mathrm{~kg}$.

Finally, the maximum fissile inventory for a 250 MWth metal core ABR which discharges fuel every two months can be estimated as

Total discharge fissile inventory $=(60-(2 / 12) \mathrm{yr}).(0.7+173.6+25.5+0.7 \mathrm{~kg} / \mathrm{yr}$.

(from Table 6.7, [Kim, 2006b])

$$
\approx 12,000 \mathrm{~kg} \text {. }
$$

BOEC core fissile inventory $=1.9+446.5+66.7+0.9 \approx 500 \mathrm{~kg}$.

(from Table 6.7, [Kim, 2006b])

Maximum 250 MWth metal fissile inventory $\approx 12,000+500=12,500 \mathrm{~kg}$.

Using the adjusted oxide fissile discharge rate and the adjusted oxide core fissile inventory calculated above for a 2000 MWth oxide core, the maximum fissile inventory for a $2000 \mathrm{MWth}$ ABR oxide core plant operating 60 years is

$$
\text { Maximum } \begin{aligned}
2000 \text { MWth oxide fissile inventory } & \approx(60-(12 / 12) \mathrm{yr} .) *(1010 \mathrm{~kg} / \mathrm{yr} .) \\
& +3760 \mathrm{~kg} . \\
& \approx 63,400 \mathrm{~kg} .
\end{aligned}
$$

The maximum fissile inventory for a 1000 MWth ABR oxide core plant operating 60 years is calculated as

Total discharge fissile inventory $=(60-($ cycle length $(\mathrm{mo})) / 12).($ discharge inv. rate $)$

$$
\begin{aligned}
& =(60-(12 / 12) \mathrm{yrs} .)(1.8+362.8+8.6 \mathrm{~kg} / \mathrm{yr}) \\
& \approx 22,000 \mathrm{~kg} .
\end{aligned}
$$

(from [Kim, 2007b])

BOEC core fissile inventory $=16.2+2137.6+21.4 \approx 2200 \mathrm{~kg}$.

(from [Kim, 2007b])

Maximum 1000 MWth oxide fissile inventory $\approx 22,000+2200 \approx 24,200 \mathrm{~kg}$.

Finally, using the adjusted oxide fissile discharge rate and the adjusted oxide core fissile inventory calculated above for a 250 MWth oxide core, the maximum fissile inventory for a $250 \mathrm{MWth} \mathrm{ABR}$ oxide core plant operating 60 years is

$$
\begin{aligned}
\text { Maximum } 250 \text { MWth oxide fissile inventory } & \approx(60-(2 / 12) \mathrm{yr} .) *(211 \mathrm{~kg} / \mathrm{yr} .) \\
& +545 \mathrm{~kg} . \\
\approx & 13,200 \mathrm{~kg} .
\end{aligned}
$$


Table 3 (radioactive and hazardous wastes from operations):

Low-level liquid waste ([CRBRP, 1977], Secs. 3.5.1.2, 3.5.1.3). In the CRBRP design, there are two systems which produce low-level liquid waste: an intermediate activity level liquid process system, which processes aqueous effluent from cleaning residual sodium and radioactivity from components removed from the primary and intermediate sodium loops, and a low activity level liquid radwaste system, which processes liquid effluents from floor drains, shower drains, and laboratory drains. Both systems decontaminate liquids by filtration, evaporation, and demineralization. Both systems discharge liquid only after sampling and analysis confirm that the liquid meets release limits. The intermediate activity level liquid process system discharges 4,000 gal. of water per year, diluted by the cooling tower blowdown. The low activity level liquid radwaste system drains 850 gal./day into a discharge stream. Combined discharge is therefore

$$
[4000 \text { gal./yr. + (850 gal./day)x(365 days/yr. })]=3.14 \times 10^{5} \text { gal./yr. }
$$

Since the CRBRP power was nearly $1000 \mathrm{MWth}$, this is the value taken for the 1000 MWth ABR. To adjust for the power difference between CRBR and a $2000 \mathrm{MWth}$ $\mathrm{ABR}$, this quantity is doubled, so the total discharge is $6.3 \times 10^{5} \mathrm{gal} . / \mathrm{yr}$. To adjust for the power difference between CRBR and a $250 \mathrm{MWth} A B R$, this quantity is cut by a factor of four, so the total discharge is $7.9 \times 10^{4} \mathrm{gal} . / \mathrm{yr}$.

Low-level solid waste ([CRBRP, 1977], Sec. 3.5.3, Table 3.5-10). Includes compactible solids (rags, paper, seals - $200 \mathrm{cu}$. ft. after compaction, assuming compaction decreases volume by a factor of ten), non-compactible solids (low activity scrapped components and components metal from cutting operations, $572 \mathrm{cu}$. ft., and resins, $450 \mathrm{cu}$. ft.), and solidified liquid radwaste (concentrated material from the bottom of the low-level and intermediate level system evaporators which is drawn off and solidified, 1,000 cu. ft.). The solidified liquid radwaste quantity was assumed to scale linearly with ABR power. Therefore, for a $2000 \mathrm{MWth}$ ABR, the total volume of low-level solid waste is estimated as

$$
\left(200+572+450+2 \mathrm{x} 1000 \mathrm{ft}^{3} .\right) /\left(27 \mathrm{yd}^{3} . / \mathrm{ft}^{3} .\right)=119 \mathrm{yd}^{3} / \mathrm{yr} .
$$

For a $1000 \mathrm{MWth} \mathrm{ABR}$, the total volume of low-level solid waste is estimated as

$$
\left(200+572+450+1000 \mathrm{ft}^{3} .\right) /\left(27 \mathrm{yd}^{3} . / \mathrm{ft}^{3} .\right)=82 \mathrm{yd}^{3} / \mathrm{yr} .
$$

and for a $250 \mathrm{MWth}$ ABR, the total volume of low-level solid waste is estimated as

$$
\left(200+572+450+1000 \mathrm{ft}^{3} . / 4\right) /\left(27 \mathrm{yd}^{3} . / \mathrm{ft}^{3} .\right)=55 \mathrm{yd}^{3} / \mathrm{yr} .
$$

Mixed low-level solid waste ([CRBRP, 1977], Sec. 3.8.3 and Sec. 3.5.3, Table 3.510). Includes control rod assemblies and drive lines and radial shield assemblies, which are both radioactive and contaminated with sodium. Also, from Table 3.5-10, Sec. 3.5.3, includes 1) filters contaminated with radioactivity and sodium (165 cu. ft.), 
2) ex-vessel storage tank sodium (42 cu. ft.), and 3) sodium-bearing solids (235 cu. ft.).

According to Sec. 3.8.3 of [CRBRP, 1977], all nineteen CRBR control rods were to be replaced every year, nineteen drive lines were to be replaced every ten years, and shield assemblies were to be replaced as follows: 72 assemblies every three years for the first row, 78 assemblies every six years for the second row, 84 assemblies every twelve years for the third row, and 90 assemblies every twenty-four years for the fourth row. ANL has not yet optimized either the number of control rods or the control rod worths for the candidate ABR cores, nor has an evaluation been done to determine the frequency with which control rods, reflectors, and shields would be replaced. Therefore, the CRBR values given in [CRBRP, 1977] for waste from replacing in-vessel components are considered the best estimate available at present. Because these numbers are only a rough estimate, no scaling for the various candidate ABR power ratings has been used. As control rod requirements and in-vessel component replacement are evaluated, the mixed low-level solid waste estimate should be revised.

Assuming control rod assemblies and shield assemblies are the same length as a fuel rod, both have dimensions 115 in. long (Fig. 3.8-2, [CRBRP, 1977]) and a hexagonal cross-section 4.7 in. across the flats (Sec. 3.8.1.1, [CRBRP, 1977]). The assembly volume is approximately

$$
\begin{aligned}
& \mathrm{V}=\mathrm{A}(\mathrm{L}) \\
& \mathrm{L}=115 \mathrm{in} . \\
& \mathrm{A}=6(4.7 / 2)\left(4.7 /(2(\operatorname{SQRT}(3))) \mathrm{in}^{2}=19.1 \mathrm{in}^{2}\right.
\end{aligned}
$$

Therefore,

$$
\mathrm{V}=(19.1)(115)=2200 \mathrm{in}^{3}=4.7 \times 10^{-2} \mathrm{yd}^{3}{ }^{3}
$$

As described above, the number of assemblies shipped each year $=19+72 / 3+78 / 6+$ $84 / 12+90 / 24$, or just under 67 per year on average (e.g., 66 or 67 each year).

Control rod assembly lines are 30 feet long and have a 2 in. outside diameter, so the volume is

$$
\mathrm{V}=30(3.14)(1)(1) \text { in. }^{3}=94.3 \text { in. }^{3}=0.002 \text { yd. }^{3}
$$

The volume of waste from control rod assemblies, drive lines, and radial shield assemblies is then

$$
\mathrm{V}=67\left(4.7 \times 10^{-2}\right)+19(.002) / 10 \mathrm{yd}^{3}{ }^{3} \text {, or } 3.2 \mathrm{yd}^{3} / \text { year. }
$$

The volume of waste from filters, metallic sodium from fuel handling operations, and sodium-bearing solids (primary, intermediate, and ex-vessel storage tank cold traps ([CRBRP, 1974], Sec. 3.4, "Solid Radwaste System,") is 


$$
\left.165+42+235 \mathrm{ft}^{3}{ }^{3} \mathrm{yr} .\right) /\left(27 \mathrm{ft}^{3} / \mathrm{yd}^{3}=8.2 \mathrm{yd}^{3}{ }^{3} / \mathrm{yr}\right. \text {. }
$$

This waste volume should scale approximately linearly with reactor power, so for a 2000 MWth ABR, the volume of waste would be about $16.4 \mathrm{yd}^{3} / \mathrm{yr}$., and for a 250 MWth ABR, the volume of waste would be about $1.1 \mathrm{yd}^{3} / \mathrm{yr}$.

An upper bound on the total amount of solid mixed low-level waste can be estimated by assuming that sodium in all sodium-bearing components will be treated off site. In this case, the total solid mixed low-level waste would be

$$
\begin{aligned}
& 16.4+3.2=19.6 \mathrm{yd}^{3} / \mathrm{yr} \text {. for a } 2000 \mathrm{MWth} \text { ABR, } \\
& 8.2+3.2=11.4 \mathrm{yd}^{3} / \mathrm{yr} \text {. for a } 1000 \mathrm{MWth} \text { ABR, } \\
& 1.1+3.2=4.3 \mathrm{yd}^{3} / \mathrm{yr} \text {. for a } 250 \mathrm{MWth} \text { ABR. }
\end{aligned}
$$

The more likely option is that metallic sodium and some or all of the sodium-bearing solids and filters would be treated on-site. In this case, the volume of mixed low-level solid waste to be disposed of off-site would be reduced accordingly.

Hazardous liquid waste ([CRBRP, 1977], Sec. 3.3.4).

The CRBRP design chemical waste treatment system discharges effluent at about 35 gal./minute, or

$$
\text { (35 gal./min.)x(60 min./hr.)x(24 hr./day)x(365 days/yr.) }=1.84 \times 10^{7} \text { gal./yr., }
$$

so a 1000 MWth ABR plant would generate about $1.84 \times 10^{7}$ gallons of hazardous liquid waste per year. Assuming the effluent volume varies approximately linearly with plant power, a $250 \mathrm{MWth}$ plant would generate about $\left(1.84 \times 10^{7}\right) / 4=4.6 \times 10^{6}$ gallons of hazardous liquid waste per year, while a $2000 \mathrm{MWth}$ plant would produce about $\left(1.84 \times 10^{7}\right) \times 2=3.7 \times 10^{7}$ gallons per year.

Hazardous solid waste ([CRBRP, 1977], Sec. 10.4.1.1.1 and Table 10.4-2).

Hazardous solid waste estimates for CRBRP were based on processing solid wastes from the cooling tower basin, neutralizing and settling facility, and sludge dewatering beds. The estimated average solid waste stream from the CRBRP chemical waste treatment system is $1,000 \mathrm{lb} / \mathrm{day}$, or $3.65 \times 10^{5} \mathrm{lb} / \mathrm{yr}$. Wastes would be somewhat less if a Brayton cycle were used. Therefore, assuming that the waste produced is approximately linearly dependent on plant power, an upper bound for the hazardous solid waste from a $250 \mathrm{MWth}$ plant would be $\left(3.65 \times 10^{5}\right) / 4=9.1 \times 10^{4} \mathrm{lb}$./yr.; for a 1000 MWth ABR plant it would be $3.65 \times 10^{5} \mathrm{lb} / \mathrm{yr}$., and for a $2000 \mathrm{MWth}$ plant, it would be $\left(3.65 \times 10^{5}\right) \times 2=7.3 \times 10^{5} \mathrm{lb} . / \mathrm{yr}$.

\section{Table 4 (non-hazardous operations wastes):}

Sanitary liquid waste ([CRBRP, 1977], Sec. 5.5). 
Assume a liquid sanitary waste figure of 25 gal./day per operations staff member and that each staff member works about 250 days per year. Total number of workers employed by a $250 \mathrm{MWth}$ plant is estimated at 300, based on employment numbers given for CRBRP (see discussion of Table 6 in Appendix A for the basis for the number of workers). The annual liquid sanitary waste produced for a $250 \mathrm{MWth}$ plant would then be

$$
25 \times 250 \times 300 \approx 1.9 \times 10^{6} \text { gallons/year }
$$

The total employment for CRBRP was expected to be 344 workers (see the discussion in Appendix A of Table 6). Since CRBRP and the 1000 MWth ABR are comparable sized plants, this is also taken to be the total employment for the $1000 \mathrm{MWth}$ ABR. The annual liquid sanitary waste produced for a 1000 MWth plant would then be

$$
25 \times 250 \times 344 \approx 2.2 \times 10^{6} \text { gallons/year }
$$

For a 2000 MWth plant, total employment is estimated at 385 workers (see the discussion of Table 6 in Appendix A). The annual liquid sanitary waste produced for a 2000 MWth plant would then be

$$
25 \times 250 \times 385 \approx 2.4 \times 10^{6} \text { gallons/year }
$$

Sanitary solid waste ([USEPA, 1999].

The reference describes a water treatment plant which treats 11 million gallons of sanitary wastewater per day (MGD) and produces 7500 cubic yards of biosolids (sludge) per year. If a $250 \mathrm{MWth}$ ABR plant processed $1.9 \times 10^{6}$ gallons of wastewater per year (see above), the annual production of biosolids to be hauled away would be $7500 \times\left(1.9 \times 10^{6}\right) /(11 \times 365) /\left(10^{6}\right)$, or approximately 3.5 cubic yards. For a $1000 \mathrm{MWth}$ plant, the annual amount of biosolids would be $7500 \times\left(2.2 \times 10^{6}\right) /(11 \times 365) /\left(10^{6}\right)$, or approximately 4.0 cubic yards. For a $2000 \mathrm{MWth}$ plant, the annual amount of biosolids would be $7500 \times\left(2.4 \times 10^{6}\right) /(11 \times 365) /\left(10^{6}\right)$, or approximately 4.5 cubic yards.

\section{$\underline{\text { Other non-hazardous solid waste }}$}

During normal plant operation, non-hazardous solid waste (i.e., ordinary trash) is produced at a rate of about $1.5 \mathrm{yd}^{3}$ per 100 employees per day. Assuming the average employee works 250 days per year, the amount of trash generated annually for a 250 MWth plant (300 employees, see Table 6) would be about $300 \times 1.5 \times 250 / 100=1150$ $\mathrm{yd}^{3}$ per year. The amount for a 1000 MWth plant (344 employees from Table 6) would be about $344 \times 1.5 \times 250 / 100=1300 \mathrm{yd}^{3}$ per year. The amount for a $2000 \mathrm{MW}$ th plant (385 employees from Table 6) would be about $385 \times 1.5 \times 250 / 100=1450 \mathrm{yd}^{3}$ per year.

\section{Table 5 (electrical requirements):}

Electrical energy and peak electrical demand. 
In-plant power consumption for the CRBR plant was projected to be $30 \mathrm{MWe}$ ([CRBRP, 1977], Sec. 3.2.3). Some of this power consumption is independent of reactor power, but the power required for the three primary sodium pumps, the three intermediate sodium pumps, and the three water recirculation pumps would scale linearly with pump volumetric flow rate, and the flow rates of all three types of pumps are assumed to scale approximately linearly with reactor power. Each CRBR primary pump and each intermediate pump was designed with a 5000 HP main motor, while each recirculation pump was designed with a 2000 HP motor ([CRBRP, 1974], Sec. 3.1 ("Primary Pump") and Sec. 3.5, Table 3-9), so at full power, these pumps would require

$$
\mathrm{P}_{\text {pumps }}=(6 \times 5000+3 \times 2000 \mathrm{HP}) \times\left(746 \times 10^{-6} \mathrm{MW} / \mathrm{HP}\right)=26.9 \mathrm{MWe} .
$$

Therefore, the portion of the CRBR plant power consumption that would be independent of reactor power is estimated as

$$
\mathrm{P}_{\text {fixed }}=30-26.9=3.1 \mathrm{MWe}
$$

This estimate is used for the fixed portion of an ABR plant power consumption.

The 250 MWth, the $1000 \mathrm{MWth}$, and the 2000 MWth ABR plant designs all include four primary sodium pumps and two intermediate sodium pumps. Both centrifugal mechanical pumps and EM pumps have been considered for the primary pumps; only EM pumps have been considered for the intermediate pumps. For the $250 \mathrm{MWth}$ plant design [Chang, 2006], the centrifugal primary pump option specifies $0.34 \mathrm{MW}$ required per pump, while the EM pump option requires $0.61 \mathrm{MW}$ per pump. Therefore, the two primary pump options for a $250 \mathrm{MWth}$ ABR would require

$$
\begin{aligned}
& \mathrm{P}_{\text {primary cent. pumps, } 250 \mathrm{MWth}}=4 \mathrm{x} 0.34=1.36 \mathrm{MWe} \\
& \mathrm{P}_{\text {primary EM pumps, } 250 \mathrm{MWth}}=4 \times 0.61=2.44 \mathrm{MWe} .
\end{aligned}
$$

Assuming primary pump power scales approximately linearly with reactor power, the two primary pump options for a $1000 \mathrm{MWth}$ ABR would require

$$
\begin{aligned}
& \mathrm{P}_{\text {primary cent. pumps, } 1000 \mathrm{MWth}}=4 \times 1.36=5.44 \mathrm{MWe} \\
& \mathrm{P}_{\text {primary EM pumps, } 1000 \mathrm{MWth}}=4 \times 2.44=9.76 \mathrm{MWe},
\end{aligned}
$$

and the two primary pump options for a $2000 \mathrm{MWth}$ ABR would require

$$
\begin{aligned}
& \mathrm{P}_{\text {primary cent. pumps, } 2000 \mathrm{MWth}}=8 \times 1.36=10.9 \mathrm{MWe} \\
& \mathrm{P}_{\text {primary EM pumps, } 2000 \mathrm{MWth}}=8 \times 2.44=19.5 \mathrm{MWe} .
\end{aligned}
$$


The intermediate pump design discussed in [Chang, 2006] specifies a power requirement of $0.41 \mathrm{MWe}$ per pump. Therefore, the intermediate pumps for a 250 MWth ABR would need

$$
\mathrm{P}_{\text {int. pumps, } 250 \mathrm{MWth}}=2 \times 0.41=0.82 \mathrm{MWe} \text {, }
$$

the intermediate pumps for a $1000 \mathrm{MWth}$ ABR would need

$$
\mathrm{P}_{\text {int. pumps, } 1000 \mathrm{MWth}}=4 \times 0.82=3.28 \mathrm{MWe} \text {, }
$$

and the intermediate pumps for a 2000 MWth ABR would need

$$
\mathrm{P}_{\text {int. pumps, } 2000 \mathrm{MWth}}=8 \times 0.82=6.56 \mathrm{MWe},
$$

The circulating water pumps in the balance-of-plant system require $0.53 \mathrm{MWe}$ for a 250 MWth plant, 2.1 MWe for a 1000 MWth plant, and 4.3 MWe for a 2000 MWth plant [Lomperski, 2007].

If the supercritical $\mathrm{CO}_{2}$ Brayton cycle is used in the power conversion system, the $\mathrm{CO}_{2}$ compressors may add considerably to the plant electrical requirements, depending upon the design option used [Sienicki, 2007]. In option 1, the two compressors are on the same shaft as the turbine such that they are driven directly by the turbine and not by electric motors. Thus, there is no motor electric power requirement. However, an alternate design possibility (option 2) is to have the compressors and turbine on three separate shafts and drive each compressor with an electric motor rather than its own dedicated turbine (in which case, a larger generator is used to make up the difference in the net power provided by the plant). If option 2 is used, the main compressor requires 27.9 MWe and the recompressing compressor requires $27.1 \mathrm{MWe}$ for a 250 MWth plant. These power demands are assumed to scale approximately linearly with reactor power, so for a $1000 \mathrm{MWth} \mathrm{ABR}$, the main compressor requires $112 \mathrm{MWe}$ and the recompressing compressor requires $108 \mathrm{MWe}$, while for a $2000 \mathrm{MWth} \mathrm{ABR}$, the main compressor requires $223 \mathrm{MWe}$ and the recompressing compressor requires 217 MWe.

Using the value of 3.1 MWe evaluated above for the fixed portion of the ABR plant electrical demand, the peak electrical demand for a 250 MWth ABR using option 1 of the supercritical $\mathrm{CO}_{2}$ Brayton cycle is then estimated as

$$
\begin{aligned}
\mathrm{P}_{\text {peak, } 250 \mathrm{MW} \text { th, Brayton option 1, cent. prim. pumps }} & =3.1+1.36+0.82+0.53 \\
& =5.8 \mathrm{MWe} \\
\mathrm{P}_{\text {peak, 250 MWth, Brayton option 1, EM prim. pumps }} & =3.1+2.44+0.82+0.53 \\
& =6.9 \mathrm{MWe}
\end{aligned}
$$

If option 2 of the Brayton cycle is selected, the power requirements become

$$
\mathrm{P}_{\text {peak, } 250 \mathrm{MWth} \text {, Brayton option 2, cent. prim. pumps }}=3.1+1.36+0.82+0.53+27.9+27.1
$$




$$
\begin{aligned}
& =60.8 \mathrm{MWe} \\
\mathrm{P}_{\text {peak, 250 MWth, Brayton option 2, EM prim. pumps }} & =3.1+2.44+0.82+0.53+27.9+27.1 \\
& =61.9 \mathrm{MWe}
\end{aligned}
$$

For a Rankine cycle power conversion system, the feedwater pumps for a 250 MWth ABR would require approximately $2.1 \mathrm{MWe}$ and the condensate pumps approximately 0.31 MWe [Lomperski, 2007]. The power requirements would then be

$$
\begin{aligned}
\mathrm{P}_{\text {peak, } 250 \mathrm{MW} \text { th, Rankine, cent. prim. pumps }} & =3.1+1.36+0.82+0.53+2.1+0.31 \\
& =8.2 \mathrm{MWe} \\
\mathrm{P}_{\text {peak, } 250 \text { MWth, Rankine, EM prim. pumps }} & =3.1+2.44+0.82+0.53+2.1+0.31 \\
= & 9.3 \mathrm{MWe}
\end{aligned}
$$

For a 1000 MWth ABR, peak electrical demand for the two primary pump options and option 1 of the Brayton cycle is estimated as

$$
\begin{aligned}
\mathrm{P}_{\text {peak, } 1000 \mathrm{MW} \text { th, Brayton option 1, cent. prim. pumps }} & =3.1+5.44+3.28+2.1 \\
& =13.9 \mathrm{MWe} \\
\mathrm{P}_{\text {peak, } 1000 \mathrm{MWth}, \text { Brayton option 1, EM prim. pumps }} & =3.1+9.76+3.28+2.1 \\
& =18.2 \mathrm{MWe} .
\end{aligned}
$$

Peak electrical demand for a 1000 MWth ABR using option 2 of the Brayton cycle and either primary pump option would be

$$
\begin{aligned}
\mathrm{P}_{\text {peak, } 1000 \text { MWth, Brayton option 2, cent. prim. pumps }} & =3.1+5.44+3.28+2.1+112+108 \\
& =234 \mathrm{MWe} \\
\mathrm{P}_{\text {peak, } 1000 \mathrm{MW} \text { th, Brayton option 2, EM prim. pumps }} & =3.1+9.76+3.28+2.1+112+108 \\
& =238 \mathrm{MWe} .
\end{aligned}
$$

For a Rankine cycle, it is assumed that the feedwater and condensate pump powers scale linearly with reactor power, so the feedwater pumps for a 1000 MWth ABR would require approximately $2.1 \times 4=8.4 \mathrm{MWe}$, and the condensate pumps would require approximately $0.31 \times 4=1.24 \mathrm{MWe}$ [Lomperski, 2007]. Therefore, peak electrical demand for a 1000 MWth ABR using a Rankine cycle and either primary pump option would be

$$
\begin{aligned}
\mathrm{P}_{\text {peak, } 1000 \mathrm{MWth}, \text { Rankine, cent. prim. pumps }} & =3.1+5.44+3.28+2.1+8.4+1.24 \\
& =23.6 \mathrm{MWe} \\
\mathrm{P}_{\text {peak, } 1000 \text { MWth, Rankine, EM prim. pumps }} & =3.1+9.76+3.28+2.1+8.4+1.24 \\
& =27.9 \mathrm{MWe} .
\end{aligned}
$$


For a $2000 \mathrm{MWth}$ ABR, peak electrical demand for the two primary pump options and option 1 of the Brayton cycle is estimated as

$$
\begin{aligned}
\mathrm{P}_{\text {peak, } 2000 \text { MWth, Brayton option 1, cent. prim. pumps }} & =3.1+10.9+6.56+4.3 \\
& =24.8 \mathrm{MWe} \\
\mathrm{P}_{\text {peak, } 2000 \text { MWth, Brayton option 1, EM prim. pumps }} & =3.1+19.5+6.56+4.3 \\
& =33.4 \mathrm{MWe} .
\end{aligned}
$$

Peak electrical demand for a 2000 MWth ABR using option 2 of the Brayton cycle and either primary pump option would be

$$
\begin{aligned}
\mathrm{P}_{\text {peak, } 2000 \mathrm{MW} \text { th, Brayton option 2, cent. prim. pumps }} & =3.1+10.9+6.56+4.3+223+217 \\
& =465 \mathrm{MWe} \\
\mathrm{P}_{\text {peak, } 2000 \mathrm{MWth}, \text { Brayton option 2, EM prim. pumps }} & =3.1+19.5+6.56+4.3+223+217 \\
& =473 \mathrm{MWe} .
\end{aligned}
$$

For a Rankine cycle, the feedwater pumps for a 2000 MWth ABR would require approximately $2.1 \times 4=8.4 \mathrm{MWe}$, and the condensate pumps would require approximately $0.31 \times 4=1.24 \mathrm{MWe}$ [Lomperski, 2007]. Therefore, peak electrical demand for a 2000 MWth ABR using a Rankine cycle and either primary pump option would be

$$
\begin{aligned}
\mathrm{P}_{\text {peak, } 2000 \text { MWth, Rankine, cent. prim. pumps }} & =3.1+10.9+6.56+4.3+16.8+2.48 \\
& =44.1 \mathrm{MWe} \\
\mathrm{P}_{\text {peak, } 2000 \text { MWth, Rankine, EM prim. pumps }} & =3.1+19.5+6.56+4.3+16.8+2.48 \\
& =52.7 \mathrm{MWe} .
\end{aligned}
$$

Estimates for maximum annual power consumption for the various $250 \mathrm{MWth} A \mathrm{BR}$ options are then

$$
\begin{aligned}
\mathrm{P}_{\text {annual, 250 MWth, Brayton option 1, cent. prim. pumps }} & =(5.8 \mathrm{MWe})^{*}(8760 \mathrm{hr} . / \mathrm{yr}) \\
& =5.09 \times 10^{4} \mathrm{MWh} \\
& =(6.9 \mathrm{MWe})^{*}(8760 \mathrm{hr} . / \mathrm{yr}) \\
\mathrm{P}_{\text {annual, } 250 \mathrm{MW} \text { th, Brayton option 1, EM prim. pumps }} & =6.04 \times 10^{4} \mathrm{MWh} \\
& =(60.8 \mathrm{MWe})^{*}(8760 \mathrm{hr} . / \mathrm{yr}) \\
\mathrm{P}_{\text {annual, 250 MWth, Brayton option 2, cent. prim. pumps }} & =5.33 \times 10^{5} \mathrm{MWh} \\
& =(61.9 \mathrm{MWe})^{*}(8760 \mathrm{hr} . / \mathrm{yr}) \\
\mathrm{P}_{\text {annual, 250 MWth, Brayton option 2, EM prim. pumps }} & =5.42 \times 10^{5} \mathrm{MWh} . \\
\mathrm{P}_{\text {annual, 250 MWth, Rankine, cent. prim. pumps }}=(8.2 \mathrm{MWe}) *(8760 \mathrm{hr} . / \mathrm{yr}) & =7.20 \times 10^{5} \mathrm{MWh}
\end{aligned}
$$




$$
\begin{aligned}
\mathrm{P}_{\text {annual, } 250 \text { MWth, Rankine, EM prim. pumps }} & =(9.3 \mathrm{MWe})^{*}(8760 \mathrm{hr} . / \mathrm{yr}) \\
& =8.15 \times 10^{5} \mathrm{MWh} .
\end{aligned}
$$

Maximum annual power consumption for the various 1000 MWth ABR options is estimated as

$$
\begin{aligned}
\mathrm{P}_{\text {annual, } 1000 \mathrm{MW} \text { th, Brayton option 1, cent. prim. pumps }} & =(13.9 \mathrm{MWe})^{*}(8760 \mathrm{hr} . / \mathrm{yr}) \\
& =1.22 \times 10^{5} \mathrm{MWh} \\
\mathrm{P}_{\text {annual, } 1000 \mathrm{MW} \text { th, Brayton option 1, EM prim. pumps }} & =(18.2 \mathrm{MWe})^{*}(8760 \mathrm{hr} . / \mathrm{yr}) \\
& =1.59 \times 10^{5} \mathrm{MWh} \\
\mathrm{P}_{\text {annual, } 1000 \mathrm{MW} \text { th, Brayton option 2, cent. prim. pumps }} & =(234 \mathrm{MWe})^{*}(8760 \mathrm{hr} . / \mathrm{yr}) \\
& =2.05 \times 10^{6} \mathrm{MWh} \\
\mathrm{P}_{\text {annual, } 1000 \mathrm{MW} \text { th, Brayton option 2, EM prim. pumps }} & =(238 \mathrm{MWe})^{*}(8760 \mathrm{hr} . / \mathrm{yr}) \\
& =2.45 \times 10^{6} \mathrm{MWh} . \\
\mathrm{P}_{\text {annual, } 1000 \mathrm{MW} \text { th, Rankine, cent. prim. pumps }} & =(23.6 \mathrm{MWe})^{*}(8760 \mathrm{hr} . / \mathrm{yr}) \\
& =2.07 \times 10^{5} \mathrm{MWh} \\
\mathrm{P}_{\text {annual, } 1000 \mathrm{MWth}, \text { Rankine, EM prim. pumps }} & =(27.9 \mathrm{MWe})^{*}(8760 \mathrm{hr} . / \mathrm{yr}) \\
= & 2.44 \times 10^{5} \mathrm{MWh} .
\end{aligned}
$$

Maximum annual power consumption for the various 2000 MWth ABR options is estimated as

$$
\begin{aligned}
\mathrm{P}_{\text {annual, } 2000 \mathrm{MW} \text { th, Brayton option 1, cent. prim. pumps }} & =(24.8 \mathrm{MWe})^{*}(8760 \mathrm{hr} . / \mathrm{yr}) \\
& =2.17 \times 10^{5} \mathrm{MWh} \\
\mathrm{P}_{\text {annual, } 2000 \mathrm{MW} \text { th, Brayton option 1, EM prim. pumps }} & =(33.4 \mathrm{MWe})^{*}(8760 \mathrm{hr} . / \mathrm{yr}) \\
& =2.93 \times 10^{5} \mathrm{MWh} \\
\mathrm{P}_{\text {annual, } 2000 \mathrm{MW} \text { th, Brayton option 2, cent. prim. pumps }} & =(465 \mathrm{MWe})^{*}(8760 \mathrm{hr} . / \mathrm{yr}) \\
& =4.07 \times 10^{6} \mathrm{MWh} \\
\mathrm{P}_{\text {annual, } 2000 \mathrm{MW} \text { th, Brayton option 2, EM prim. pumps }} & =(473 \mathrm{MWe})^{*}(8760 \mathrm{hr} . / \mathrm{yr}) \\
& =4.15 \times 10^{6} \mathrm{MWh} . \\
\mathrm{P}_{\text {annual, } 2000 \mathrm{MW} \text { th, Rankine, cent. prim. pumps }}=(44.1 \mathrm{MWe})^{*}(8760 \mathrm{hr} . / \mathrm{yr}) & =3.86 \times 10^{5} \mathrm{MWh} \\
\mathrm{P}_{\text {annual, } 2000 \mathrm{MW} \text { th, Rankine, EM prim. pumps }} & =(52.7 \mathrm{MWe})^{*}(8760 \mathrm{hr} . / \mathrm{yr}) \\
= & 4.62 \times 10^{5} \mathrm{MWh} .
\end{aligned}
$$


Table 6 (operations data):

Emergency generator fossil fuel usage ([CRBRP, 1977], Tables 3.7-2 and 5.5-1; [CRBRP, 1974], Sec. 4.4, "Emergency Power System", and Sec. 3.1, "Primary Pump"; [Chang, 2006], Sec. 2.9.6)

The only fossil fuel usage identified for CRBR is for the two emergency diesel generators and the diesel fire pump. From [CRBRP, 1977], Table 5.5-1, fuel consumption for each is $95 \mathrm{lbs} . / \mathrm{hr}$ of No. 2 oil. Per [CRBRP, 1977], Table 3.7.2, each engine is run for 24 hours/year for testing. According to [CRBRP, 1974], Sec. 4.4, each diesel generator is rated at 3.3 MWe. The 250 MWth ABR plant design ([Chang, 2006], Sec. 2.9.6) includes two 1 MWe emergency generators and considers the option of making the generators either diesel or gas. If diesel generators were used, and if the fuel usage scales approximately linearly with generator size, the mass of fuel used per year for a $250 \mathrm{MWth}$ ABR plant would be

$$
\mathrm{M}=2(24 \mathrm{~h} . / \mathrm{yr} .)(95 \mathrm{lbs} / \mathrm{hr} \text {. for } 3.3 \mathrm{MWe}) / 3.3=1382 \mathrm{lbs} \text { No. } 2 \mathrm{oil} / \mathrm{yr} .
$$

The density of No. 2 oil is 7.05 lb./gal. [Perry, 1997]. Therefore, the volume of fuel used per year for emergency generator testing for a $250 \mathrm{MWth} A B R$ plant would be:

$$
\mathrm{V}=1382 \mathrm{lbs} / \mathrm{yr} /(7.05 \mathrm{lb} . / \mathrm{gal} .) \approx 200 \mathrm{gal} . / \mathrm{yr} .
$$

The ABR 1000 MWth design assumes that the emergency generator capacity consists of two $3 \mathrm{MWe}$ generators, or $6 \mathrm{MWe}$, so the volume of fuel used per year for a 2000 MWth ABR plant would be

$$
\mathrm{V} \approx(200 \text { gal./yr. }) \times 3=600 \text { gal./yr. }
$$

The ABR 2000 MWth design assumes that the emergency generator capacity consists of four $3 \mathrm{MWe}$ generators, or $12 \mathrm{MWe}$, so the volume of fuel used per year for a 2000 MWth ABR plant would be

$$
\mathrm{V} \approx(200 \text { gal. } / \mathrm{yr} .) \times 6=1200 \text { gal. } / \mathrm{yr} .
$$

Grounds maintenance fossil fuel usage

Assume that diesel powered equipment is used 25 times per year for grounds maintenance and that 5 gallons of fuel are consumed per hour by all the equipment used. Also, assume that maintenance can be completed on three acres each hour. From Table 27, a 250 MWth plant will have about 80 acres committed to landscaped facilities, so the amount of fossil fuel consumed in grounds maintenance per year would be about $80 \times 25 \times 5 / 3 \approx 3350$ gal./yr. For a 1000 MWth plant, Table 27 indicates 100 acres of landscaped facilities, so the fossil fuel consumption for grounds maintenance would be about $100 \times 25 \times 5 / 3 \approx 4200$ gal./yr. Finally, for a $2000 \mathrm{MWth}$ plant, Table 27 shows 120 acres of landscaped facilities, so the fossil fuel consumption for grounds maintenance would be about $120 \times 25 \times 5 / 3=5000$ gal./yr. 
Process gases ([Chang, 2006], Secs. II.10.1 and II.10.17).

Nitrogen. If the Rankine cycle option is selected for the power conversion system, nitrogen would be used for sparging in the steam generators. Sparging occurs when a steam generator is taken out of service either due to malfunction of a piece of equipment or for maintenance. Hydrazine would be injected into the water in the steam generator, then nitrogen gas would be blown in through the bottom of the steam generator to mix the hydrazine with the water and to blanket the water. A $6900 \mathrm{MWth}$ commercial nuclear plant (two 3450 MWth reactors) uses about 200,000 scf (one tanker truck) of nitrogen per year for steam generator sparging [Flores, 2007]. The quantity of nitrogen used will scale approximately linearly with plant power. A 250 MWth ABR would therefore require about $(200,000) \times(250 / 6900) \approx 7300$ scf of nitrogen annually, a 1000 MWth ABR plant would require about $(200,000) \times(1000 / 6900)=29,000$ scf of nitrogen annually, and a 2000 MWth ABR plant would require about $(200,000) \times(2000 / 6900)=58,000 \mathrm{scf}$ of nitrogen per year.

Hydrogen. Both 1000 and 2000 MWth ABR plants would probably use a generator cooled by hydrogen. Hydrogen flow and initial charge to such a generator are discussed in [Smith, 2002], which describes a GE Frame 7 gas turbine generator as taking an initial charge of 7,500 $\mathrm{ft}^{3}$ of hydrogen gas for purge and filling and requiring $21 \mathrm{ft}^{3}$ of hydrogen gas per hour for makeup. Hydrogen-cooled generators for the 903 MWe generating plant at Zeeland, Michigan are discussed in [Mirant, 2007] and [Speranza, 2005]. These three generators require a total of about $70 \mathrm{scf} / \mathrm{hr}$. of hydrogen makeup for cooling. Assuming each of these generators also takes an initial charge of about 7,500 scf of hydrogen gas, the Zeeland plant would require about $3 \times 7500+70 \times 24 \times 365=635,700$ scf of hydrogen per year. Assuming that hydrogen required would scale approximately linearly with total generator power, a rough estimate of the hydrogen requirements of a $1000 \mathrm{MWth}$ ABR plant generator (380 MWe, assuming 38\% efficiency) would be about $(380 / 903) \times 635,700=268,000$ scf/yr., while the hydrogen requirements of a $2000 \mathrm{MWth}$ ABR plant generator (760 MWe, assuming 38\% efficiency) would be about (760/903)x635,700 = 535,000 scf/yr. The volume ratio between hydrogen gas at $1 \mathrm{~atm}$. and liquid hydrogen is about 825 . Therefore, a 1000 MWth ABR generator would require about 268,000/825 = $325 \mathrm{ft}^{3}$ of liquid hydrogen per year., while a $2000 \mathrm{MWth}$ ABR generator would require about $535,000 / 825=650 \mathrm{ft}^{3}{ }^{3}$ of liquid hydrogen per year. If hydrogen is delivered to the site and stored on-site in tanks in liquid form, and assuming liquid hydrogen deliveries about five times per year, a reasonable quantity to store onsite for a $1000 \mathrm{MWth}$ plant would be about $70 \mathrm{ft}^{3}$, and for a $2000 \mathrm{MWth}$ plant about $150 \mathrm{ft}^{3}$. If a hydrogen generator is used to generate hydrogen continuously, only a reserve of a few days needs to be stored on site. Assuming a reserve for six days, about $(70 \times 24 \times 6) \times(380 / 903) / 825=5 \mathrm{ft}^{3}$ of liquid hydrogen would be stored on-site as reserve for a $1000 \mathrm{MWth} \mathrm{ABR}$, and about $(70 \times 24 \times 6) \times(760 / 903) / 825=10 \mathrm{ft}^{3}$ for a $2000 \mathrm{MWth}$ ABR. For a 1000 MWth ABR, approximately $(3 \times 7500) \times 380 / 903)=$ 9,500 scf of hydrogen gas would be required to purge and charge the generator, and for a 2000 MWth ABR, approximately $(3 \times 7500) \times(760 / 903)=19,000$ scf would be required. 
Carbon Dioxide. For the preconceptual design $250 \mathrm{MWth}$ ABR plant, the $\mathrm{CO}_{2}$ inventory in the $\mathrm{S}-\mathrm{CO}_{2}$ Brayton cycle is $10,800 \mathrm{~kg}$. There will also be a cryogenic storage tank or tanks located near to the turbine generator building holding additional $\mathrm{CO}_{2}$ needed for makeup to compensate for any losses and to recharge the system if it needs to be depressurized for maintenance or repair. The inventory in the storage $\operatorname{tank}(\mathrm{s})$ is estimated as four times the cycle inventory, or $43,200 \mathrm{~kg}$. Thus, the total $\mathrm{CO}_{2}$ onsite during normal operation is $(10,800+43,200)=54,000 \mathrm{~kg}$., or about $963,000 \mathrm{scf}$, since $\mathrm{CO}_{2}$ has a density of $1.98 \mathrm{~kg} / \mathrm{m}^{3}$ at standard temperature and pressure, or $0.056 \mathrm{~kg} / \mathrm{scf}$. There is a need for a flow of $\mathrm{CO}_{2}$ for the shaft seals on the turbomachinery. It is anticipated that this $\mathrm{CO}_{2}$ will be captured for reuse and not vented. It is also anticipated that leakages from the cycle will be negligible. These numbers should scale roughly linearly with the power level such that, for a 1000 MWth plant, there would be four times as much, or $216,000 \mathrm{~kg}$ (3.9 million scf) of $\mathrm{CO}_{2}$ onsite, while for a $2000 \mathrm{MWth}$ plant, there would be eight times as much, or $432,000 \mathrm{~kg}$ (7.7 million scf) of $\mathrm{CO}_{2}$ onsite. [Sienicki, 2007]

\section{Chemical Use ([CRBRP, 1977], Sec 3.6, Fig. 3.6-1)}

Sodium hypochlorite. The CRBRP design called for intermittent injection of sodium hypochlorite for bio-fouling control in the cooling tower water (maximum of 450 lb./day) and in the ground water intake (maximum of $180 \mathrm{lb}$./day), plus minor amounts to the sanitary system discharge. Thus, a 1000 MWth plant should require $450+180=630 \mathrm{lb}$. per day. Assuming the requirements for this chemical scale linearly with water volume, which should scale approximately linearly with plant power, a 250 MWth ABR would require a maximum daily addition of $(450+180) / 4 \approx 160 \mathrm{lb}$, while a 2000 MWth ABR would take at most $(450+180) \times 2=1260$ lb. per day.

Sulfuric acid. This chemical was to be added occasionally to the CRBRP cooling tower water and the chemical waste treatment system to control high $\mathrm{pH}$. A maximum of $3400 \mathrm{lb}$./day was specified, so a $1000 \mathrm{MWth}$ plant would need a maximum of 3400 lb./day. Scaling this quantity linearly with power would result in a $250 \mathrm{MW}$ th ABR plant requiring occasional addition of $3400 / 4=850 \mathrm{lb}$. of sulfuric acid per day, while a $2000 \mathrm{MW}$ th plant would receive $3400 \times 2=6800 \mathrm{lb}$.

Sodium hydroxide. The CRBRP chemical waste treatment system was expected to require a maximum of $2200 \mathrm{lb}$. of sodium hydroxide a day on an intermittent basis, so a 1000 MWth ABR would be expected to require occasional addition of at most 2200 lb per day. Adjusting linearly for power, a $250 \mathrm{MWth}$ ABR plant chemical waste treatment system would use $2200 / 4=550 \mathrm{lb}$. of sodium hydroxide per day on occasion, while a $2000 \mathrm{MWth}$ plant would periodically require $2200 \times 2=4400 \mathrm{lb}$./day.

Steam ([CRBRP, 1977], Sec. 3.2, Table 3.2-1)

Steam is used only if a steam generator is used in the power conversion system. In this case, steam would be the working fluid within the closed loop of the steam generator. For CRBR, steam flow to the turbine would be $3.34 \times 10^{6} \mathrm{lb} / \mathrm{hr}$., or 


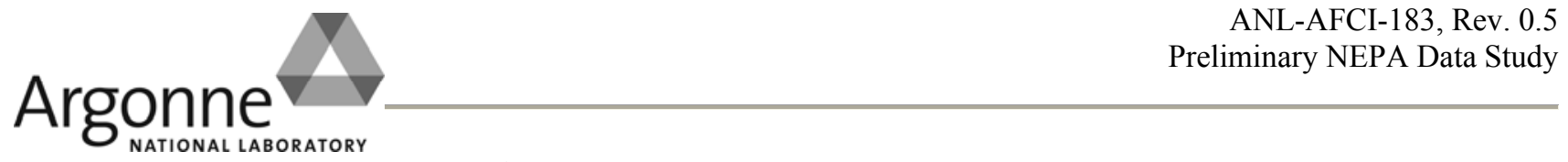

$\left(3.34 \times 10^{6} \mathrm{lb} / \mathrm{hr} . \times 24 \mathrm{hr} . /\right.$ day $\left.\times 365 \mathrm{~d} / \mathrm{yr}\right) /(2000 \mathrm{lb} /$ ton $)=1.46 \times 10^{7} \mathrm{ton} / \mathrm{yr}$.

Assuming steam produced varies approximately linearly with reactor power, then steam flow for a $1000 \mathrm{MWth}$ ABR would be $1.46 \times 10^{7}$ ton/yr., for a $2000 \mathrm{MW}$ th ABR, steam flow $=2.92 \times 10^{7} \mathrm{ton} / \mathrm{yr}$., and for a $250 \mathrm{MWth} \mathrm{ABR}$, steam flow $=3.66 \times 10^{6}$ ton/yr.

Hydrazine. If a Rankine cycle is used, hydrazine would be added to the feedwater as an oxygen scavenger. Hydrazine is used to control oxygen in the steam cycle at nearly all U. S. nuclear power plants. The quantity of hydrazine added scales approximately with reactor power. A $6900 \mathrm{MWth}$ nuclear plant (two $3450 \mathrm{MWth}$ reactors) requires 15,000 gal. of hydrazine per year and receives deliveries of the chemical three times per year [Flores, 2007]. A 250 MWth ABR would therefore require about $(15,000) \times(250 / 6900)=550$ gal. of hydrazine per year and would store at most 200 gal. at one time, a $1000 \mathrm{MWth}$ ABR would require about $(15,000) \times(1000 / 6900)=2,200$ gal. annually and would store at most 750 gal. at one time. and a $2000 \mathrm{MWth}$ ABR would require about $(15,000) \times(2000 / 6900)=4,400$ gal. annually and would store at most 1500 gal. at one time.

Monoethanolamine. If a Rankine cycle is used, the steam and water must be kept alkaline in order to control corrosion. An organic amine is added to the water to control pH; nearly all U. S. power plants use one of the following three: monoethanolamine, morpholine, or ammonia. Of these, monoethanolamine distributes best throughout the system and controls $\mathrm{pH}$ in the condensate the best. A $6900 \mathrm{MWth}$ nuclear plant requires 35,000 gal. of monoethanolamine per year and receives the chemical in eight shipments per year [Flores, 2007]. The plant therefore stores at most 4500 gal. at one time. The quantity of the chemical required scales approximately linearly with reactor power. A 250 MWth ABR would therefore require about 1300 gal. of monoethanolamine annually and, if it followed the same delivery schedule, would store less than 200 gal. at a time. A 1000 MWth ABR would use about 5,100 gal. annually and would store about 650 gal. at a time, and a 2000 MWth ABR would use about 10,200 gal. annually and would store about 1300 gal. at a time.

Employment. Values expected for the CRBRP are found in [CRBRP, 1977], Sec. 3.7.1, and_[CRBRP, 1982], Ch. 13, Figure 13.1-2: CRBRP Organizational Chart. It was expected that there would be 125 workers present on site at any one time during normal operations, with 210 workers on site at any one time during the annual service shutdown. Total employment of the plant was expected to be 344 workers. A certain number of these were rad workers, as describe in [CRBRP, 1982], Ch. 13, Figure 13.1-2: CRBRP Organizational Chart. Rad workers were taken to be all workers in health physics, engineering, operations, and plant maintenance, other than the following: Training, Shift Clerks, Janitor and Labor Services Supervisor. The total number of employees classified as rad workers would then be:

$$
69+(59-10)+15+59+35+4+21 \approx 250
$$


These numbers should be representative of employment at a $1000 \mathrm{MWth}$ ABR.

To reflect some economy of scale regarding plants of different sizes, the employment numbers for the $250 \mathrm{MWth}$ plant were taken as about $88 \%$ of those for the CRBRP, while the employment numbers for the $2000 \mathrm{MWth}$ plant were assumed to be about $112 \%$ of those for the CRBRP.

\section{Table 7 (makeup water usage):}

Water usage ([CRBRP, 1977], Sec. 3.3, Table 3.3-1 and Figure 3.3-1; [Tawney, 2003])

The CRBR plant was designed with a mechanical draft wet cooling tower, which represents most of the plant makeup water. The remainder of the water makeup goes to process waste treatment, which includes chemical waste treatment, radwaste systems, the potable water and sanitary waste systems, demineralizer regenerations, and the condensate polishing system, which treats condensate to maintain the feedwater chemistry needed by the steam generator. Systems other than the cooling tower require on average $67 \mathrm{gpm}$ of water, with a peak design capacity of $125 \mathrm{gpm}$ $\left(6.57 \times 10^{7}\right.$ gal. $/ \mathrm{yr}$. $)$. At $975 \mathrm{MWth}$, the cooling tower requires $7,050 \mathrm{gpm}\left(3.71 \times 10^{9}\right.$ gal./yr.) of makeup water, with $2,700 \mathrm{gpm}\left(1.42 \times 10^{9}\right.$ gal./yr. $)$ returned to the water source, $4,240 \mathrm{gpm}\left(2.23 \times 10^{9} \mathrm{gal} . / \mathrm{yr}\right.$. $)$ lost to evaporation, and $110 \mathrm{gpm}\left(5.78 \times 10^{7}\right.$ gal./yr.) lost to drift (droplets of water discharged from the system during operation). Waste water to be processed is therefore the sum of the water used in process waste treatment plus cooling tower blowdown, or $(125+2,700)=2,825 \mathrm{gpm}\left(1.49 \times 10^{9}\right.$ gal./yr.) The water requirements are assumed to vary linearly with reactor operating power and to be approximately independent of the type of wet cooling tower used, as shown in Table 7.

If dry cooling technology is used instead of a wet cooling system, no makeup water is required by the plant heat sink, and the makeup water requirements are limited to those for process water treatment, plus a minor amount to compensate for any leaks in the power conversion system if a Rankine cycle is used.

\section{Table 8 (spent fuel discharge):}

From Table 3.4 in [Kim, 2006a],

metal 2000 MWth startup core spent fuel discharge $\approx 5560 \mathrm{~kg}$. HM/yr.

From [Kim, 2007b],

metal $1000 \mathrm{MWth}$ startup core spent fuel discharge $\approx 3100 \mathrm{~kg}$. HM/yr.

From Table 6.7 in [Kim, 2006b],

metal 250 MWth startup core spent fuel discharge $\approx 850 \mathrm{~kg}$. HM/yr. 
As covered above in the discussion of Table 1, the 2000 MWth oxide core discussed in [Kim, 2006a] has a higher TRU conversion ratio than the $2000 \mathrm{MWth}$ metal core, and so, in order to estimate annual discharge for the oxide core on the same basis as for the metal core, the oxide core must be adjusted as follows to achieve the same TRU conversion ratio as the metal core.

For a 2000 MWth oxide core,

oxide HM discharge rate = oxide HM charge rate - oxide HM consumption

If the oxide core achieves the same conversion ratio as the metal core, then

oxide core HM consumption = metal core HM consumption

$$
\text { = metal startup core HM charge - }
$$
metal startup core HM discharge

(from Table 3.4, [Kim, 2006a])

$$
\begin{aligned}
& =6233.0-5558.5 \mathrm{~kg} . / \mathrm{yr} . \\
& \approx 675 \mathrm{~kg} . / \mathrm{yr} .
\end{aligned}
$$

The oxide HM charge rate is adjusted for the TRU conversion ratio as follows:

oxide adj. HM charge rate $=($ oxide TRU charge rate at the orig. conv. ratio) $\mathrm{x}$ (metal HM charge rate)/(metal TRU charge rate)

$$
\begin{aligned}
& =(1468.9) *(6233.0 / 1422.1) \\
& \approx 6440 \mathrm{~kg} / \mathrm{yr} .
\end{aligned}
$$

(from Table 3.4, [Kim, 2006a])

The adjusted oxide HM discharge rate is then

2000 MWth startup oxide core HM discharge rate $\approx 6440-675 \approx 5760 \mathrm{~kg}$. $/ \mathrm{yr}$.

Similarly, for a 250 MWth oxide core,

oxide $\mathrm{HM}$ discharge rate = oxide $\mathrm{HM}$ charge rate - oxide HM consumption

If the oxide core achieves the same conversion ratio as the metal core, then

oxide core $\mathrm{HM}$ consumption = metal core $\mathrm{HM}$ consumption

$$
\text { = metal startup core HM charge - }
$$$$
=932.7-848.2 \mathrm{~kg} . / \mathrm{yr} \text {. }
$$
metal startup core HM discharge

(from Table 6.7, [Kim, 2006b])

The oxide HM charge rate is adjusted for the TRU conversion ratio as follows: oxide adj. HM charge rate $=$ (oxide TRU charge rate at the orig. conv. ratio) $\mathrm{x}$ 
(metal HM charge rate)/(metal TRU charge rate)

$=(449.2) *(932.7 / 431.0)$

$\approx 973 \mathrm{~kg} / \mathrm{yr}$.

(from Tables 6.7 and 6.8, [Kim, 2006b])

The adjusted oxide HM discharge rate is then

250 MWth startup oxide core HM discharge rate $\approx 973-85 \approx 890 \mathrm{~kg} . / \mathrm{yr}$

The spent fuel discharge for the 1000 MWth oxide startup core is taken directly from [Kim, 2007b] as

1000 MWth startup oxide core HM discharge rate $\approx 2500 \mathrm{~kg}$. HM/yr.

Both metal and oxide 1000 MWth ABR cores contain 180 fuel assemblies and have a cycle length of one year. However, the fuel is dicharged in four batches for the metal core, and so the 1000 MWth metal ABR discharges 180/4 $=45$ assemblies per year, whereas the oxide core fuel is discharged in five batches, or 180/5 $=36$ assemblies per year.

\section{Table 11 (hazardous air pollutants):}

References: [CRBRP, 1977], Table 3.7-2; [Chang, 2006], Sec. 2.9.6.

Hazardous air pollutants would be released to the atmosphere during testing or emergency operation of the emergency generators and during use of diesel-powered equipment for grounds maintenance. Assuming the emergency generators are diesel powered, emissions can be estimated from data for CRBR plant diesel operation in [CRBRP, 1977], Table 3.7-2. CRBR diesels included the two 3.3 MWe emergency diesel generators and a diesel fire pump. Since no data on the diesel fire pump could be found, it was conservatively assumed that the total maximum air pollutants given in Table 3.7-2 could be attributed to testing of the two emergency generators. The total maximum pollutant releases given in Table 3.7-2 are

\begin{tabular}{|c|r|}
\hline Pollutant & Release, ton/yr. \\
\hline $\mathrm{SO}_{2}$ & 0.75 \\
\hline Hydrocarbons & 0.75 \\
\hline $\mathrm{NO}_{\mathrm{x}}$ & 7.5 \\
\hline $\mathrm{CO}$ & 1.5 \\
\hline
\end{tabular}

Assume that these releases are from testing of two 3.3 MWe generators and that 1) emissions scale approximately linearly with generator fuel usage and 2) fuel usage scales approximately linearly with generator power. The 250 MWth ABR plant design includes two 1.0 MWe emergency generators, the 1000 MWth design assumes two 3.0 MWe emergency generators, and the 2000 MWth plant design includes four 3.0 MWe emergency generators. Therefore, the maximum annual emissions for 
testing emergency diesel generators for both sizes of plant should be approximately as given in Table A.3 below.

\begin{tabular}{|c|c|c|c|c|}
\hline \multicolumn{5}{|c|}{$\begin{array}{l}\text { Table A.3. Approximate Annual Release of Hazardous Air Pollutants During } \\
\text { Emergency Diesel Generator Testing and Grounds Maintenance }\end{array}$} \\
\hline Pollutant & & Releas & ton/yr. & \\
\hline & Plant Size & Generator Testing & Grounds Maintenance & Total \\
\hline \multirow{3}{*}{$\mathrm{SO}_{2}$} & 250 MWth & $0.75 / 3.3=0.23$ & $0.23 \times(3350 / 200)=3.9$ & 4.1 \\
\hline & $1000 \mathrm{MW}$ th & $(0.75 / 3.3) * 3=0.68$ & $0.23 \times(4200 / 200)=4.8$ & 5.5 \\
\hline & 2000 MWth & $(0.75 / 3.3) * 6=1.36$ & $0.23 \times(5000 / 200)=5.7$ & 7.1 \\
\hline \multirow{3}{*}{ Hydrocarbons } & $250 \mathrm{MWth}$ & $0.75 / 3.3=0.23$ & $0.23 \times(3350 / 200)=3.9$ & 4.1 \\
\hline & 1000 MWth & $(0.75 / 3.3) * 3=0.68$ & $0.23 \times(4200 / 200)=4.8$ & 5.5 \\
\hline & $2000 \mathrm{MWth}$ & $(0.75 / 3.3) * 6=1.36$ & $0.23 \times(5000 / 200)=5.7$ & 7.1 \\
\hline \multirow{3}{*}{$\mathrm{NO}_{\mathrm{x}}$} & $250 \mathrm{MWth}$ & $7.5 / 3.3=2.3$ & $2.3 \times(3350 / 200)=39$ & 41 \\
\hline & $1000 \mathrm{MW}$ th & $(7.5 / 3.3) * 3=6.8$ & $2.3 \times(4200 / 200)=48$ & 45 \\
\hline & $2000 \mathrm{MWth}$ & $(7.5 / 3.3) * 6=13.6$ & $2.3 \times(5000 / 200)=57$ & 71 \\
\hline \multirow{3}{*}{$\mathrm{CO}$} & $250 \mathrm{MWth}$ & $1.5 / 3.3=0.46$ & $0.46 \times(3350 / 200)=7.7$ & 8.2 \\
\hline & $1000 \mathrm{MW}$ th & $(1.5 / 3.3) * 3=1.36$ & $0.46 \times(4200 / 200)=9.7$ & 11.0 \\
\hline & $2000 \mathrm{MWth}$ & $(1.5 / 3.3) * 6=2.73$ & $0.46 \times(5000 / 200)=11.4$ & 14.1 \\
\hline
\end{tabular}

Testing of the emergency generators for the 250 MWth ABR would consume about 200 gallons of diesel fuel per year (see discussion above of Table 6). Grounds maintenance would require about 3350 gallons of diesel fuel per year for the 250 MWth ABR, about 4200 gallons per year for the $1000 \mathrm{MWth}$ ABR, and about 5000 gallons per year for the $2000 \mathrm{MWth}$ ABR (again, see the discussion above of Table 6). Assuming the grounds maintenance equipment produces about the same amount of air pollutants per gallon of diesel fuel as the emergency generators, the air pollutants released annually from grounds maintenance would scale linearly with the amount of diesel fuel consumed. Therefore, grounds maintenance for each size of ABR plant would produce the quantities of pollutants shown in Table A.3.

\section{Table 12 (low-level waste):}

Information taken from [CRBRP, 1977], Table 3.5-11. One 55-gallon drum is eqiuivalent to $7.4 \mathrm{ft}^{3}$. The estimates of numbers of containers required per year given in [CRBRP, 1977] appear to also account for empty space within the drum for each waste type. The table combines filters, which are mixed low-level waste (due to sodium residue), with resins, which are low-level waste, so the quantity for resins was estimated by scaling the total value (100 55-gallon drums) using the annual volume numbers for resins (450 $\left.\mathrm{ft}^{3}\right)$ and filters $\left(165 \mathrm{ft}^{3}\right)$ from [CRBRP, 1977], Table 3.5-10. This gives

No. of drums containing resins $=100(450 /(450+165)=73$ drums 
The total number of drums of non-compactible solids is the sum of the number of drums of scrapped components ( 82 from Table 3.5-11) and the number of drums of resins, or $73+82=155$.

The only waste which scales with reactor power is the solidified liquid radwaste (140 drums for CRBR), so this value was scaled directly with candidate ABR power.

\section{Table 26 (construction requirements):}

Construction period: Figure A.1 plots construction time vs. plant power for 41 U.S. power reactors [IAEA, ]. The plot indicates that plants around $2000 \mathrm{MWth}$ took about six years to complete, so the construction time estimate for the 2000 MWth ABR has been taken as six years. This is an estimate for time during which construction activities are in progress; delays due to regulatory issues, etc., during which construction work may be suspended, are not included, since construction wastes, fossil fuel emissions, etc. will not be generated and thus the idle time will have little, if any, environmental impact.

Since construction employment is adjusted for plant size, construction time is not expected to vary much with plant size, since the larger the plant size, the more staff and equipment are available for tasks such as pouring concrete, installing electrical systems, etc. Therefore, it is estimated that a 250 MWth ABR would take perhaps a year less to build than a 2000 MWth plant, or five years and that a 1000 MWth ABR would take about 5.5 years to build.

Construction employment: CRBRP total employment and peak employment are taken from Sec. 8.2, Table 8.2-1, [CRBRP, 1977]. These values are then scaled by $\left(\mathrm{P}_{\mathrm{ABR}}\right) /\left(\mathrm{P}_{\mathrm{CRBR}}\right)^{0.7}$

Construction peak electrical requirements: This parameter has been estimated by looking at a comparable size of construction project, the Spallation Neutron Source. According to [Lawson, 2007], a 9 MWe line supplied the electrical needs of about 800 construction workers during the 6.5 year construction period, or about $11.25 \mathrm{~kW}$ per worker. Assuming this estimate is applicable to ABR construction, a 250 MWth plant would require about $780 \times 11.25 \approx 9$ MWe maximum during construction, while a 1000 MWth plant would need about $2050 \times 11.25 \approx 23$ MWe maximum and a 2000 MWth plant would need about $3330 \times 11.25 \approx 38 \mathrm{MWe}$ maximum during construction.

Diesel or gas generators would be used during construction ([Chang, 2006], Sec. 11.9.6). The current design calls for two 1 MWe back-up generators for the 250 MWth plant, two 3 MWe back-up generators for the 1000 MWth plant, and four $3 \mathrm{MWe}$ back-up generators for the 2000 MWth plant. Thus, either temporary generators would be needed during construction to supplement the permanent back-up generators, or a temporary power line would need to be installed for construction. 
Concrete used in construction: Concrete estimate from Sec. 4.3.3, [CRBRP, 1977] is $200,000 \mathrm{yd}^{3}$, so the amount of concrete needed to construct a $1000 \mathrm{MWth}$ ABR would be about $200,000 \mathrm{yd}^{3}$. If a volume-to-power factor of

$$
\left(\mathrm{V}_{\mathrm{ABR}}\right) /\left(\mathrm{V}_{\mathrm{CRBR}}\right)=\left(\mathrm{P}_{\mathrm{ABR}}\right) /\left(\mathrm{P}_{\mathrm{CRBR}}\right)^{0.7}
$$

is used, similar to that described in Appendices B and C, and using $\mathrm{P}_{\mathrm{CRBR}}=1000$ MWth, then the amount of concrete for a 250 MWth ABR can be estimated as

$$
250 \text { MWth ABR concrete }=200,000 \times(250 / 1000)^{0.7}=76,000 \mathrm{yd}^{3},
$$

while the amount for a 2000 MWth ABR would be estimated as

$$
2000 \text { MWth ABR concrete }=200,000 \times(2000 / 1000)^{0.7}=325,000 \mathrm{yd}^{3},
$$

Steel used in construction: Details used in making the steel estimates are given in the spreadsheet table provided in Appendix C.

Use of liquid fuel and lube oil during construction: The major tasks requiring liquid fuel and lube oil are site preparation, excavation, hauling, backfill, and site finishing. Table A.4 presents details of the assumptions and data taken from [Caterpillar, 1990] and applied to the estimated land requirements and concrete usage for the two bounding ABR designs to generate estimates for liquid fuel and lube oil requirements during construction.

Construction water usage: A construction water usage estimate is available for CRBRP from Sec. 4.1.2.1, [CRBRP, 1977]. This value is consistent with assuming 25 gallons of water used per day per worker. Peak daily construction water use can therefore be estimated by multiplying the anticipated number of workers in the peak year by 25 .

\section{Table 27 (construction land requirements):}

Land requirements are calculated from the CRBRP land requirements found in [CRBRP, 1977], Sec. 4.1 and Table 4.1-1. The CRBRP site was expected to cover 1,364 acres total, most of it natural wooded area. Table 4.1-1 of [CRBRP, 1977] provides a detailed breakdown of the types of land usage included in the laydown area during construction. Land usage for a 250 MWth plant is assumed to be $80 \%$ of that for CRBRP, while land for a 2000 MWth plant is assumed to be $120 \%$ of CRBRP, to a first approximation. Land usage for a 1000 MWth plant is taken as the CRBRP estimate, with the total site area rounded to 1400 acres.

Laydown area for the CRBRP is given as 156 acres in [CRBRP, 1977], Table 4.1-1. This value is rounded to 160 acres for the $1000 \mathrm{MWth} \mathrm{ABR}$ plant. The laydown area is scaled for reactor power by $\left(\mathrm{P}_{\mathrm{ABR}} / \mathrm{P}_{\mathrm{CRBR}}\right)^{0.7}$, so for the $250 \mathrm{MWth} \mathrm{ABR}$, the laydown area is calculated as $(156) \times(250 / 1000)^{0.7}$, or 60 acres, and for the $2000 \mathrm{MWth} A B R$, the laydown area is $(156) \mathrm{x}(2000 / 1000)^{0.7}$, or 250 acres. 


\section{Table A.4. Estimation of Liquid Fuel and Lube Oil Consumed During ABR Construction}

Supporting data from [Caterpillar, 1990]

\begin{tabular}{|l|l|l|l} 
Land clearing & 250 MWth & 1000 MWth & 2000 MWth
\end{tabular}

Assume light vegetation, level terrain, good footing, clay subsoil.

Assume area cleared is equal to Facilities, Laydown, and Temp parking areas (see Table 27).

Assume D7H, Weldco brush rake, medium duty load factor

\begin{tabular}{|l|r|r|r|}
\hline Area to be cleared (acres) (from Table 27) & 145 & 272 & 390 \\
\hline Hours per acre & 1.8 & 1.8 & 1.8 \\
\hline Gallons per hour & 9 & 9 & 9 \\
\hline Gallons per acre cleared & 16.2 & 16.2 & 16.2 \\
\hline Fuel for land clearing (gal) & $\mathbf{2 3 4 9}$ & $\mathbf{4 4 0 6}$ & $\mathbf{6 3 1 8}$ \\
\hline
\end{tabular}

Site preparation

Assume site prep includes construction of roads and preliminary utility work, drainage.

Assume site is nominally flat $(<10 \%$ grade), clay subsoil, with good footing.

Assume site prep work is equal to twice plant area (see Table 27).

Area to be prepped (acres)

Gallons per acre prepped

Fuel for site prep (gal)

\section{Excavation}

\begin{tabular}{|r|r|r|}
6 & 8 & 10 \\
\hline 255 & 255 & 255 \\
\hline $\mathbf{1 5 3 0}$ & $\mathbf{2 0 4 0}$ & $\mathbf{2 5 5 0}$ \\
\hline
\end{tabular}

Assume excavation volume is equal to four times the volume of concrete placed.

Assume excavation is by hydraulic excavator, hauling by articulated dump.

Concrete volume (yd. $\left.{ }^{3}\right)$ (from Table26)

Excavation volume (yd. $\left.{ }^{3}\right)(4 \mathrm{x}$ concrete volume)

Excavation productivity $\left(\mathrm{yd} .{ }^{3} / \mathrm{hr}\right)$

Excavation fuel consumption (gal/hr)

Excavation fuel (gal)

Hauling

Assume excavation spoil is hauled 0.3 miles for storage/reuse.

Haul/dump volume (yd. ${ }^{3}$ ) (excavation volume, see above)

Haul productivity $\left(\mathrm{yd}^{3} / \mathrm{hr}\right)$

Haul fuel consumption (gal/hr)

Haul/dump fuel (gal)

\section{Backfill}

\begin{tabular}{|r|r|r|}
\hline 76000 & 200000 & 325000 \\
\hline 304000 & 800000 & 1300000 \\
\hline 375 & 375 & 375 \\
\hline 14.5 & 14.5 & 14.5 \\
\hline $\mathbf{1 1 7 5 5}$ & $\mathbf{3 0 9 3 3}$ & $\mathbf{5 0 2 6 7}$ \\
\hline
\end{tabular}

Assume backfill/disposition requires same amount of fuel to load/haul/dump as Exc + Haul.

Backfill / disposition fuel (gal) Site finishing

Assume site finishing requires same amount of fuel as land clearing.

\begin{tabular}{|l|r|r|r|}
\hline Site finishing fuel (gal) & 2349 & 4406 & $\mathbf{6 3 1 8}$ \\
\hline & & & \\
\hline Fuel for misc equipment (gal) & 15000 & 30000 & $\mathbf{6 0 0 0 0}$ \\
\hline Total fuel (gal) & 59615 & $\mathbf{1 4 3 6 4 6}$ & $\mathbf{2 4 3 0 6 8}$ \\
\hline \multicolumn{3}{|r|}{} & \\
\hline Assume that lube oil and grease consumption is 1.2\% of fuel volume, per Caterpillar data. \\
\hline Lube oil and grease (gal) & $\mathbf{7 1 5}$ & $\mathbf{1 7 2 4}$ & 2917 \\
\hline
\end{tabular}


Permanent parking areas are calculated assuming 120 parking spaces per acre and 1.4 employees on average per car. Allowing for shift change overlap and temporary contract staff during shutdown periods, permanent parking for a $250 \mathrm{MWth}$ plant can be estimated from the total number of plant employees as 300/(120x1.4), rounded up to 2 acres. For a 1000 MWth plant, permanent parking can be estimated as $344 /(120 x 1.4)$, or about 2 acres. For a 2000 MWth plant, permanent parking can be estimated as $385 /(120 \times 1.4)$, rounded up to 3 acres.

Temporary parking lot size is estimated using the peak employment figures and the same assumptions as for permanent parking lots. Thus, temporary parking for a 250 MWth plant can be estimated as $780 /(120 \times 1.4)$, rounded up to 5 acres. For a 1000 MWth plant, temporary parking can be estimated as $2050 /(120 \times 1.4)$, or about 12 acres. For a $2000 \mathrm{MWth}$ plant, permanent parking can be estimated as 385/(120x1.4), rounded up to 20 acres.

\section{Table 28 (construction wastes):}

Hazardous liquid and solid wastes: see Appendix B, Table B.2.

Sanitary liquid and solid wastes ([CRBRP, 1977], Sec. 4.1.1.5 and Table 8.2-1; Appendix B, Table B.3)

These two references differ considerably in estimates of sanitary liquid waste. The CRBR report lists a capacity to process a peak of 61,250 gallons per day, comprised of normal domestic sanitary wastewater, including laundry wastes and sink and toilet wastes. Liquid sanitary wastes were planned to be treated in an on-site treatment system during both construction and operations, with sludge to be collected and disposed of off-site by a contractor. Very limited use was to be made of chemical toilets. Assuming liquid sanitary waste of $25 \mathrm{gal} / \mathrm{person} /$ day and the annual construction employment figures from Table 8.2-1, total liquid sanitary waste during construction would be

$$
365(150+450+1000+1500+1980+1483+450 / 4)=61,000,000 \text { gal. },
$$

which is a reasonable estimate of the liquid sanitary wastes during construction for a $1000 \mathrm{MWth}$ ABR plant. If the CRBR liquid sanitary wastes are scaled by a power factor, as described in Appendix B, then for construction of a 2000 MWth plant,

$$
\text { Liquid sanitary waste }=(61,000,000)^{*}(2000 / 1000)^{0.7} \approx 99,000,000 \text { gal } .
$$

and for construction of a $250 \mathrm{MWth}$ plant,

$$
\text { Liquid sanitary waste }=(61,000,000)^{*}(250 / 1000)^{0.7} \approx 23,000,000 \text { gal } .
$$

By contrast, the analysis presented in Table B.3 assumes sanitary liquid waste to be exclusively from waterless portable toilets, with this waste then transported off site to be processed. Because the ABR plant design has not yet developed to the point of 
addressing sanitary waste expected during construction, both approaches are included in this document.

Solid sanitary wastes are assumed to be generated primarily by lunch waste and hand cleaning. The analysis described in Appendix B, Table B.3 estimates the mass of these untreated wastes from ten years of data on per capita solid wastes generated in Missouri. No average density value is estimated, so the solid waste estimate is given in tons.

Other non-hazardous wastes: see Appendix B, Table B.4. 
Appendix B: ABR Construction Wastes Spreadsheet Tables

Construction wastes for an $\mathrm{ABR}$ plant have been estimated primarily based upon information from construction of an existing reactor power generating station. Information was organized in a spreadsheet which was then used to perform the necessary calculations. Tables B.1 through B.6 list each sheet in the spreadsheet. Table B.1 summarizes the assumptions and results of the evaluation. Tables B.2 through B.4 provide details of the calculations for hazardous wastes, sanitary wastes, and other nonhazardous wastes. Tables B.5 and B.6 provide information supporting the calculations.

\section{Table B.1. Summary of Waste Generated During Construction of a Commercial Scale Advanced Burner Reactor.}

\begin{tabular}{|c|c|c|c|c|c|c|}
\hline & \multicolumn{2}{|c|}{250 MWth } & \multicolumn{2}{|c|}{1000 MWth } & \multicolumn{2}{|l|}{2000 MWth } \\
\hline & Solid & Liquid & Solid & Liquid & Solid Liquid Units & Source/Factor \\
\hline Hazardous/Special Waste & 1.3 & 25.4 & 3.7 & 73.8 & 6.6130 .8 tons $c$ & omparable project est. \\
\hline Sanitary Waste & 436 & 750 & 1,150 & 1,980 & $1,8683,217$ tons $p$ & er capita-day \\
\hline Other Waste & 5,692 & 342 & 15,022 & 904 & $24,403 \quad 1,468$ tons $p$ & er trade hours \\
\hline
\end{tabular}

\section{Assumptions:}

Greenfield site - no prior structures to remove, no D\&D.

Estimates include only waste generated on site.

Soil spoil will be reused on site.

Landscape and land clearing debris (green wood materials) will be reused onsite.

Construction period - from site planning through initial commissioning.

Reasonable efforts will be made to reduce, reuse, reclaim, recycle.

No on-site residential workers.

Assume craft hours scale by PWR/ABR Cost Factor.

Reasonable efforts will be made to avoid specification and use of hazardous/special materials.

Wastewater will be separated from surface runoff.

Liquid sanitary wastes - assumed based on primary use of no-flush portable toilets.

(Same qty of sanitary waste would be generated w/wo ABR project.) ???

Sanitary wastes are similar to those generated if manpower were on another project or stayed home.

Waste generated will scale proportionate to ABR Cost Factor. Waste comes from purchased material (packaging, waste, scrap) and purchased labor hours, so a reasonable first-order assumption is that the amount of waste is proportional to dollar cost.

\begin{tabular}{|c|c|c|c|}
\hline \multicolumn{4}{|l|}{ Cost/Power Factor } \\
\hline \multicolumn{4}{|c|}{$\begin{array}{l}\text { Assume: }(\text { cost / COST })=(\text { power / POWER })^{\wedge} 0.7 \\
(\text { empirical correlation that compensates for economies of scale) }\end{array}$} \\
\hline & 250 MWth & 1000 MWth & 2000 MWth \\
\hline Power factor exponent & 0.7 & 0.7 & 0.7 \\
\hline PWR Power, MWe & 1144 & 1144 & 1144 \\
\hline ABR Power (Pth), MWth & 250 & 1000 & 2000 \\
\hline ABR Power effiency(Pe/Pth) & $39 \%$ & $39 \%$ & $39 \%$ \\
\hline ABR Power (Pe), MWe & 97.5 & 390 & 780 \\
\hline ABR/PWR cost factor & 0.18 & 0.47 & 0.76 \\
\hline
\end{tabular}

Note: Cost/Power factor was estimated from PWR information because this information was not available for CRBR, since CRBR was never actually built. 


\section{Argonne}

\section{Table B.2. ABR Construction Hazardous / Special Waste}

Includes:Oils, paints and thinners, cleaners, sealants, glues and adhesives, batteries, pesticides

\section{Hazardous Waste - Solid}

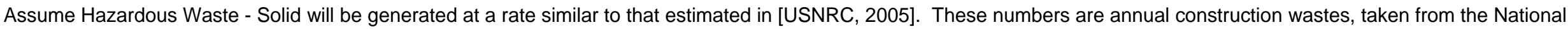

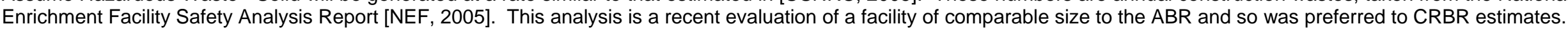

\section{MWth}

Adhesives, resins, sealers, caulking

Lead (batteries)

Estimated density of adhesives, etc. (varies from 1 to $2 \mathrm{~g} / \mathrm{cc}$; $1 \mathrm{~g} / \mathrm{cc}$

$=1 / 5.93 \mathrm{E}-04 \mathrm{lb} / \mathrm{cu}$. yd. $1 \mathrm{~g} / \mathrm{cc}$ chosen as a conservative value for density)

Density of lead (11.35 g/cc - CRC Handbook of Tables for Engineering Science)

Annual ABR Construction Hazardous Waste - Solid

Years for construction

Total ABR Construction Hazardous Waste - Solid

\begin{tabular}{|c|c|c|c|c|c|}
\hline \multicolumn{2}{|r|}{ vit } & & \\
\hline $466.5 \mathrm{lb} / \mathrm{yr}$ & $0.277 \mathrm{yd}^{3} / \mathrm{yr}$ & $1231.1 \mathrm{lb} / \mathrm{yr}$ & $0.730 \mathrm{yd}^{3} / \mathrm{yr}$ & $2000 \mathrm{lb} / \mathrm{yr}$ & $1.186 \mathrm{yd}^{3} / \mathrm{yr}$ \\
\hline $46.7 \mathrm{lb} / \mathrm{yr}$ & $0.002 \mathrm{yd}^{3} / \mathrm{yr}$ & $123.11 \mathrm{lb} / \mathrm{yr}$ & $0.006 \mathrm{yd}^{3} / \mathrm{yr}$ & $200 \mathrm{lb} / \mathrm{yr}$ & $0.010 \mathrm{yd}^{3} / \mathrm{yr}$ \\
\hline \multicolumn{6}{|l|}{$1,686 \mathrm{lb} / \mathrm{yd} .^{3}$} \\
\hline \multicolumn{6}{|l|}{$19,140 \mathrm{lb} / \mathrm{yd} .^{3}$} \\
\hline $\begin{array}{l}0.26 \text { ton/yr } \\
5.0\end{array}$ & $0.279 \mathrm{yd}^{3} / \mathrm{yr}$ & $\begin{array}{c}0.68 \text { ton/yr } \\
5.5\end{array}$ & $0.74 \mathrm{yd}^{3} / \mathrm{yr}$ & $\begin{array}{l}1.10 \text { ton/yr } \\
6.0\end{array}$ & $1.196 \mathrm{yd}^{3} / \mathrm{yr}$ \\
\hline 1.283 ton & 1.395 yd. $^{3}$ & 3.724 ton & $4.051 \mathrm{yd}^{3}$ & 6.6 ton & 7.179 yd. $^{3}$ \\
\hline
\end{tabular}

\section{Hazardous Waste - Liquid}

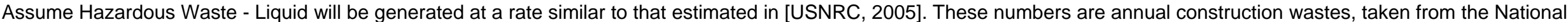
Enrichment Facility Safety Analysis Report [NEF, 2005].

Paints, solvents, thinners, organics

Petroleum products, oils, lubricants

Sulfuric acid (batteries)

Pesticides

\section{Annual ABR Construction Hazardous Waste}

- Liquid

Years for construction

Total ABR Construction Hazardous Waste -

Liquid

\begin{tabular}{rr}
\multicolumn{3}{c}{1000 MWth } \\
$12,927 \mathrm{lb} / \mathrm{yr}$ & $1,847 \mathrm{gal} / \mathrm{yr}$ \\
$12,927 \mathrm{lb} / \mathrm{yr}$ & $1,847 \mathrm{gal} / \mathrm{yr}$ \\
$492 \mathrm{lb} / \mathrm{yr}$ & $62 \mathrm{gal} / \mathrm{yr}$ \\
$492 \mathrm{lb} / \mathrm{yr}$ & $62 \mathrm{gal} / \mathrm{yr}$
\end{tabular}

13.42 ton/yr $3,817 \mathrm{gal} / \mathrm{yr}$ 5.5

\section{MWth}

$$
\begin{array}{rr}
21,000 \mathrm{lb} / \mathrm{yr} & 3,000 \mathrm{gal} / \mathrm{yr} \\
21,000 \mathrm{lb} / \mathrm{yr} & 3,000 \mathrm{gal} / \mathrm{yr} \\
800 \mathrm{lb} / \mathrm{yr} & 100 \mathrm{gal} / \mathrm{yr} \\
800 \mathrm{lb} / \mathrm{yr} & 100 \mathrm{gal} / \mathrm{yr}
\end{array}
$$

$21.80 \mathrm{ton} / \mathrm{yr} \quad 6,200 \mathrm{gal} / \mathrm{yr}$ 6.0

130.8 ton 


\section{Argonne}

\section{Table B.3. ABR Construction Sanitary Waste Generation}

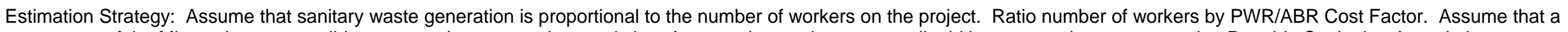

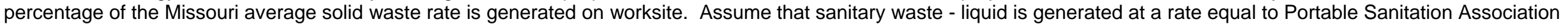
International data.

\section{Missouri Solid Waste Generation - Ten Year History [MDNR, 2006]}

\begin{tabular}{|c|c|c|c|c|c|c|c|c|c|c|c|}
\hline Year & 1990 & 1991 & 1992 & 1993 & 1994 & 1995 & 1996 & 1997 & 1998 & 1999 & 2000 \\
\hline Population & $5,117,073$ & $5,157,507$ & $5,193,872$ & $5,237,867$ & $5,281,280$ & $5,226,784$ & $5,358,692$ & $5,402,058$ & $5,438,559$ & $5,468,338$ & $5,595,211$ \\
\hline Missouri Solid Waste Generation (tons) & $7,540,000$ & $7,623,009$ & $7,844,367$ & $8,107,229$ & $8,411,596$ & $8,563,780$ & $8,771,303$ & $9,048,000$ & $9,227,853$ & $9,559,890$ & $10,288,232$ \\
\hline per capita ton/yr & 1.5 & 1.5 & 1.5 & 1.5 & 1.6 & 1.6 & 1.6 & 1.7 & 1.7 & 1.7 & 1.8 \\
\hline per capita Ib/day & 8.1 & 8.1 & 8.3 & 8.5 & 8.7 & 9.0 & 9.0 & 9.2 & 9.3 & $\begin{array}{r}9.6 \\
\text { AVG }\end{array}$ & $\begin{array}{r}10.1 \\
8.9\end{array}$ \\
\hline
\end{tabular}

ABR Construction Sanitary Waste - Solid

Assume daytime sanitary waste - solid will be a percentage of Missouri daily per capita average.

Primarily lunch waste and hand washing waste

\section{MWth 1000 MWth 2000 MWth}

Missouri daily avg per capita (lb)

Ratio - daytime factor

Craft man-hours, median, PWR

ABR/PWR cost factor

Craft man-hours, median, ABR

Sanitary Waste - Solid (Ib.)

Sanitary Waste - Solid (ton)

\section{ABR Construction Sanitary Waste - Liquid}

Primarily toilet waste - Assume predominantly waterless portable toilet

Assume liquid waste is proportionate to labor hours.

$\begin{array}{rrr}250 \text { MWth } & 1000 \text { MWth } 2000 \text { MWth } \\ 4.90 \mathrm{E}+05 & 1.29 \mathrm{E}+06 & 2.10 \mathrm{E}+06 \\ 3.1 & 3.1 & 3.1 \\ 1.50 \mathrm{E}+06 & 3.96 \mathrm{E}+06 & 6.43 \mathrm{E}+06 \\ 750 & 1,980 & 3,217 \\ \mathbf{1 . 9 6 E}+05 & \mathbf{5 . 1 8 E + 0 5} & \mathbf{8 . 4 1 E + 0 5}\end{array}$

Craft man-days, median, ABR Avg daily per capita SW-L (lb) Sanitary Waste - Liquid (lb.)

Sanitary Waste - Liquid (ton) Sanitary Waste - liquid (gal.)
$2.30 \mathrm{E}+06 \quad 3.74 \mathrm{E}+06$

1,868
Craft man-days, median, ABR

PORTABLE SANITATION ASSOCIATION INTERNATIONAL -800-822-3020 • (952) 854-8300 - Fax: (952) 854-7560 • E-mail: portsan U.S.A.

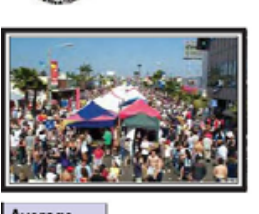

SPECIAL EVENT EXTENDED CHART BREAKDOWN Number of Units required when no pumping service is provided
$50 / 50$ Mix of Men \& Women One unit provides approximately 200 use with 4 hours between uses

\begin{tabular}{|c|c|c|c|c|c|c|c|c|c|c|}
\hline \multirow{2}{*}{\begin{tabular}{|l|}
$\begin{array}{l}\text { Average } \\
\text { Crowd } \\
\text { Size }\end{array} \mid$ \\
\end{tabular}} & \multicolumn{10}{|c|}{ AVERAGE HOURS AT THE EVENT } \\
\hline & $\Rightarrow 1$ & 2 & 3 & 4 & 5 & 6 & 7 & 8 & 9 & 10 \\
\hline 500 & 2 & 4 & 4 & 5 & 6 & 7 & 9 & 9 & 10 & 12 \\
\hline 1,000 & 4 & 6 & 8 & 8 & 9 & 9 & 11 & 12 & 13 & 13 \\
\hline 2,000 & 5 & 6 & 9 & 12 & 14 & 16 & 18 & 20 & 23 & 25 \\
\hline 3,000 & 6 & 9 & 12 & 16 & 20 & 24 & 26 & 30 & 34 & 38 \\
\hline 4,000 & 8 & 13 & 16 & 22 & 25 & 30 & 35 & 40 & 45 & 50 \\
\hline 5,000 & 12 & 15 & 20 & 25 & 31 & 38 & 44 & 50 & 56 & 63 \\
\hline 10,000 & 15 & 25 & 38 & 50 & 63 & 75 & 88 & 100 & 113 & 125 \\
\hline
\end{tabular}

gallons each unit

pound per gallon
20 number of users/day

7.65

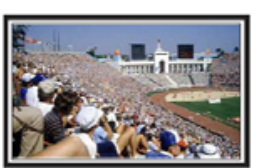

2000

3.06 


\title{
Argonne
}

\section{Table B.4. Other ABR Non-Hazardous Construction Waste}

Construction waste generated on site will be similar in nature and volume to waste generated during construction of a similar sized industrial facility.

\author{
Other Waste - Solid \\ material trimmings \\ packaging materials \\ spoiled materials \\ rebar scraps \\ crates, skids \\ carpet scraps \\ drywall scraps
}

Assume generation rates by craft man-hours, see Table B.5.

Assume waste generation scales by cost factor.

\begin{tabular}{|c|c|c|c|c|c|c|}
\hline & \multicolumn{2}{|c|}{250 MWth } & \multicolumn{2}{|c|}{1000 MWth } & \multicolumn{2}{|c|}{2000 MWth } \\
\hline PWR Other & 31906 ton & $1.82 \mathrm{E}+05 \mathrm{yd}^{3}$ & 31906 ton & $1.82 \mathrm{E}+05 \mathrm{yd}^{3}$ & 31906 ton & $1.82 \mathrm{E}+05 \mathrm{yd}^{3}$ \\
\hline WR cost factor & 0.178 & 0.178 & 0.471 & 0.471 & 0.765 & 0.765 \\
\hline ABR Other Waste - Solid & 5,692 ton & $3.24 \mathrm{E}+04 \mathrm{yd}^{3}$ & 15,022 ton & $8.56 \mathrm{E}+04 \mathrm{yd}^{3}$ & 24,403 ton & $1.39 \mathrm{E}+05 \mathrm{yd}^{3}$ \\
\hline
\end{tabular}

\section{Other Waste - Liquid}

Water from washing and cleaning (density $=1 \mathrm{~kg} / \mathrm{m} .{ }^{3}$ )

Assume generation rates by craft man-hours, see Table B.5.

Assume waste generation scales by cost factor.

PWR Other Waste - Liquid

ABR/PWR cost factor

ABR Other Waste - Liquid

\begin{tabular}{cc}
\multicolumn{3}{c}{ 250 MWth } \\
1919 ton & $4.60 \mathrm{E}+05$ gal. \\
0.178 & 0.178 \\
$\mathbf{3 4 2}$ ton & $\mathbf{8 . 2 1 E + 0 4}$ gal.
\end{tabular}

1000 MWth

$\begin{array}{cc}1919 \text { ton } & 4.60 \mathrm{E}+05 \mathrm{gal} . \\ 0.471 & 0.471 \\ \mathbf{9 0 4} \text { ton } & \mathbf{2 . 1 7 E + 0 5 ~ g a l .}\end{array}$

2000 MWth

$\begin{array}{lc}1919 \text { ton } & 4.60 \mathrm{E}+05 \mathrm{gal} . \\ 0.765 & 0.765 \\ \mathbf{1 , 4 6 8} \text { ton } & \mathbf{3 . 5 2 E + 0 5} \text { gal. }\end{array}$




\section{Table B.5. Man-hours to Construct a Power Station}

Per [USDOE, 1988] -

Direct Craft Man-hours for 1144MWe PWR Power Generating Station.

\begin{tabular}{|c|c|c|c|c|c|c|}
\hline Craft & $\begin{array}{l}\text { Median Man- } \\
\text { hours }\end{array}$ & $\begin{array}{l}\text { Better Man- } \\
\text { hours }\end{array}$ & $\begin{array}{l}\text { week, in } \mathrm{p} \\
\text { pounds }\end{array}$ & $\begin{array}{l}\text { Project, in } \\
\text { tons }\end{array}$ & $\begin{array}{l}\text { week, In } \\
\text { pounds }\end{array}$ & $\begin{array}{l}\text { project, in } \\
\text { tons }\end{array}$ \\
\hline Boiler Makers & 951,041 & 667,062 & 100 & 1189 & 5 & 59 \\
\hline Bricklayers & 340,127 & 215,368 & 350 & 1488 & 10 & 43 \\
\hline Carpenters & $1,718,442$ & $1,322,745$ & 200 & 4296 & 5 & 107 \\
\hline Electricians & $3,817,045$ & $2,201,879$ & 90 & 4294 & 2 & 95 \\
\hline Ironworkers & $2,276,271$ & $1,314,267$ & 100 & 2845 & 5 & 14 \\
\hline Laborers & $2,469,131$ & $1,587,579$ & 125 & 3858 & 10 & 3 \\
\hline Millwrights & 241,073 & 192,938 & 100 & 301 & 5 & 15 \\
\hline Operating Engineers & $1,635,640$ & 903,182 & 50 & 1022 & 2 & 41 \\
\hline Painters & 744,695 & 292,610 & 100 & 931 & 20 & 18 \\
\hline Pipe Fitters & $6,904,749$ & $3,025,010$ & 125 & 10789 & 10 & 86 \\
\hline Sheet Metal Workers & 359,071 & 160,302 & 100 & 449 & 10 & \\
\hline Teamsters & 355,036 & 154,652 & 50 & 222 & 2 & \\
\hline \multirow[t]{3}{*}{ All Others } & 177,453 & 150,412 & 100 & 222 & 2 & \\
\hline & & & Sum & 31906 & Sum & 1919 \\
\hline & $21,989,774$ & $12,188,006$ & & & & \\
\hline
\end{tabular}

\section{Table B.6. Weight to Volume Conversions}

\begin{tabular}{|c|c|c|}
\hline Material & $\begin{array}{r}\text { Conversion Rate } \\
300.0\end{array}$ & $\begin{array}{l}\text { Units } \\
\text { Ibs./yd. }{ }^{3}\end{array}$ \\
\hline \multirow[t]{2}{*}{ Wood } & 6.7 & $\mathrm{yd} .^{3} /$ ton \\
\hline & $30-100$ & lbs./yd. ${ }^{3}$ \\
\hline \multirow[t]{2}{*}{ Cardboard (loose) } & $20-50$ & yd. ${ }^{3} /$ ton \\
\hline & 400.0 & lbs./yd. ${ }^{3}$ \\
\hline \multirow[t]{2}{*}{ Drywall } & 5.0 & yd. $/$ ton \\
\hline & 350.0 & lbs./yd. ${ }^{3}$ \\
\hline Mixed Waste & 5.7 & yd. $/$ ton \\
\hline
\end{tabular}




\section{Argonne}

Appendix C: ABR Plant Steel Requirements Spreadsheet Table

Table C.1 below shows the spreadsheet table assembled to estimate steel usage in constructing an ABR plant. Estimates are given for a 250 MWth, a 1000 MWth, and a 2000 MWth plant. Estimates are based on an actual PWR because it was felt that steel usage would be better estimated from actual detailed construction information on a commercial PWR than from much less detailed information on CRBR, which was never constructed.

Table C.1. Advanced Burner Reactor Steel Requirements

\begin{tabular}{|c|c|c|c|c|c|c|c|c|c|}
\hline \multirow[b]{2}{*}{ Structures per ABR Plans } & \multirow[b]{2}{*}{$L(f t)$} & \multirow[b]{2}{*}{ W (ft) } & \multicolumn{2}{|c|}{2000 MWth } & \multicolumn{2}{|c|}{1000 MWth } & \multicolumn{2}{|c|}{250 MWth } & \\
\hline & & & Area (SF) & Roofed & Area (SF) & Roofed & Area (SF) & Roofed & \\
\hline Security Gate House & 30 & 30 & 900 & 900 & 900 & 900 & 900 & 900 & \\
\hline Control Bldg, 1000 and 2000 & 131 & 96 & 12576 & 12576 & 12576 & 12576 & & & \\
\hline Control Bldg, 250 & 89 & 71 & & & & & 6319 & 6319 & \\
\hline BOP Bldg, 1000 and 2000 & 260 & 161 & 41860 & 41860 & 41860 & 41860 & & & \\
\hline BOP Bldg, 250 & 72 & 46 & & & & & 3312 & 3312 & \\
\hline Reactor Bldg, 1000 and 2000 & 204 & 204 & 41616 & 41616 & 41616 & 41616 & & & \\
\hline Reactor Bldg, 250 & 89 & 89 & & & & & 7921 & 7921 & \\
\hline Fuel Handling Facility, all & 100 & 60 & 6000 & 6000 & 6000 & 6000 & 6000 & 6000 & \\
\hline Fuel Storage Facility, 1000 and 2000 & 307 & 187 & 57409 & 57409 & 57409 & 57409 & & & \\
\hline Fuel Storage Facility, 250 & 250 & 125 & & & & & 31250 & 31250 & \\
\hline RW/Maint Facility, 1000 and 2000 & 120 & 200 & 24000 & 24000 & 24000 & 24000 & & & \\
\hline RW/Maint Facility, 250 & 100 & 60 & & & & & 6000 & 6000 & \\
\hline Switch Yard & 100 & 89 & 8900 & & 8900 & & 8900 & & \\
\hline BOP Services Bldg, 1000 and 2000 & 100 & 90 & 9000 & 9000 & 9000 & 9000 & & & \\
\hline BOP Services Bldg, 250 & 50 & 45 & & & & & 2250 & 2250 & \\
\hline Cooling Tower, 2000 (two) & 156 dia & & 38227 & & & & & & \\
\hline Cooling Tower, 1000 & 156 dia & & & & 19113 & & & & \\
\hline Cooling Tower, 250 (four) & 48.5 & 48.5 & & & & & 2352 & & \\
\hline
\end{tabular}




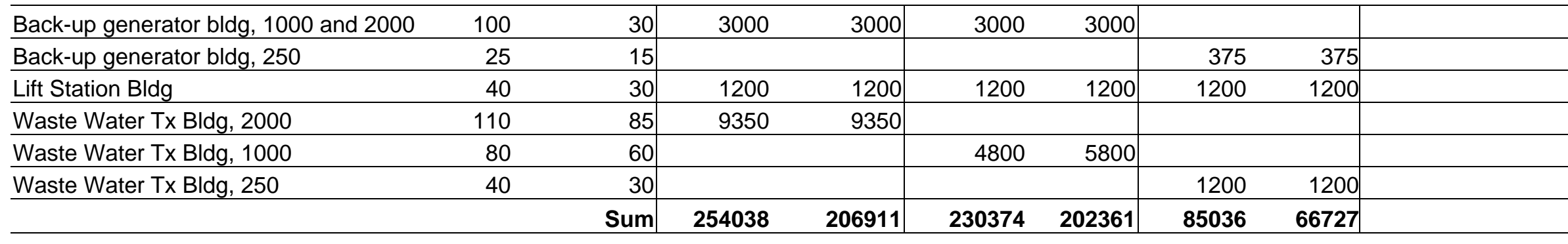

\section{Volume/Power factor to scale various size facilities.}

Data derived from 1144 MWe PWR

Convert to 250,1000 , and 2000 MWth

\section{Volume/Power Factor}

Assume: (volume / VOLUME) $=(\text { power / POWER })^{\wedge} 0.7$

\begin{tabular}{|l|r|r|r|}
\hline & $\mathbf{2 5 0} \mathbf{~ M W}$ & $\mathbf{1 0 0 0} \mathbf{~ M W}$ & $\mathbf{2 0 0 0} \mathbf{~ M W}$ \\
\hline Volume factor exponent & 0.7 & 0.7 & 0.7 \\
\hline PWR Power, MWe & 1144 & 1144 & 1144 \\
\hline ABR Power, MWth & 250 & 1000 & 2000 \\
\hline ABR Power efficiency (Pe/Pth) & $39 \%$ & $39 \%$ & $39 \%$ \\
\hline ABR Power, MWte & 97.5 & 390 & 780 \\
\hline ABR/PWR cost factor & $\mathbf{0 . 1 7 8}$ & $\mathbf{0 . 4 7 1}$ & $\mathbf{0 . 7 6 5}$ \\
\hline 250/2000 cost factor & $\mathbf{0 . 2 3 3}$ & & \\
\hline $\mathbf{1 0 0 0 / 2 0 0 0 ~ c o s t ~ f a c t o r ~}$ & $\mathbf{0 . 6 1 6}$ &
\end{tabular}

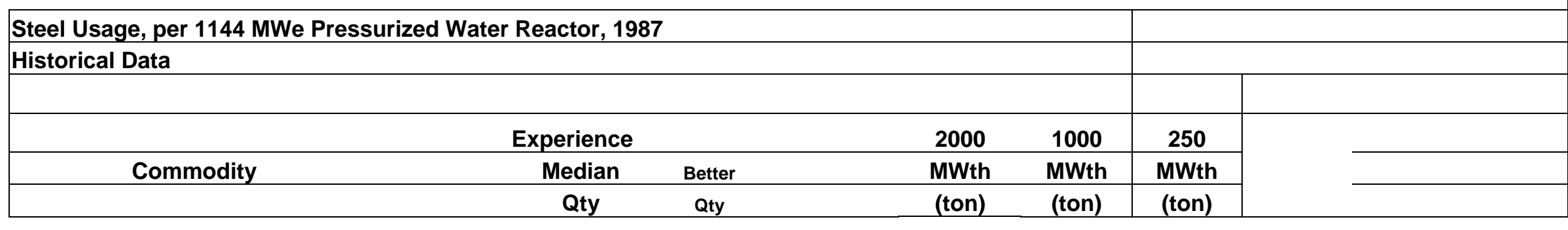

Advanced Burner Reactor Facility 


\section{Reinforcing steel}

Embedded steel

Structural steel

Carbon steel piping (NS)

Stainless steel piping (NS)

Carbon steel piping (NNS)

Stainless steel piping (NNS)

\begin{tabular}{|llllllll|}
\hline Sum(ton) & 43,845 & 33,186 & Sum(ton) & 33534 & 20643 & 7822 \\
\hline
\end{tabular}

NS - Nuclear Safety Grade

NNS - Non-Nuclear Safety Grade

\section{Steel Used in Reactor}

\section{Equivalent Volumes and Masses}

by rectangular approximations, at $2000 \mathrm{MWth}$, adjusted to 250 and $1000 \mathrm{MWth}$.

\begin{tabular}{|c|c|c|c|c|c|c|c|}
\hline & Qty & $\mathbf{L}$ & $\mathbf{W}$ & $\mathbf{T}$ & v & Density & Steel Weight \\
\hline & & in & in & in & in^3 & Ib/in^3 & Tons \\
\hline Primary Vessel & 1 & 1319 & 688 & 2 & 1814944 & 0.29 & 263.2 \\
\hline Secondary Vessel & 1 & 1400 & 700 & 1 & 980000 & 0.29 & 142.1 \\
\hline Core \& support & 1 & 100 & 100 & 50 & 500000 & 0.29 & 72.5 \\
\hline Redan & 1 & 1450 & 435 & 1 & 630750 & 0.29 & 91.5 \\
\hline Cover & 1 & 1000 & 1000 & 3 & 3000000 & 0.29 & 435.0 \\
\hline $\mathrm{IHX}$ & 4 & 1150 & 150 & 0.5 & 345000 & 0.29 & 50.0 \\
\hline Primary Pump/Motor & 4 & 1500 & 16 & 16 & 1536000 & 0.29 & 222.7 \\
\hline Sample service equipment & 1 & 1200 & 60 & 1 & 72000 & 0.29 & 10.4 \\
\hline Secondary Piping & 1 & 1200 & 31.4 & 0.6 & 22608 & 0.29 & 3.3 \\
\hline \multirow[t]{4}{*}{ Miscellaneous } & 1 & 100 & 25 & 25 & 62500 & 0.29 & 9.1 \\
\hline & & & & & & Sum & 1300 tons \\
\hline & & & & 1000 & 2000 & 250 & \\
\hline & & & & MWth & MWth & MWth & \\
\hline
\end{tabular}




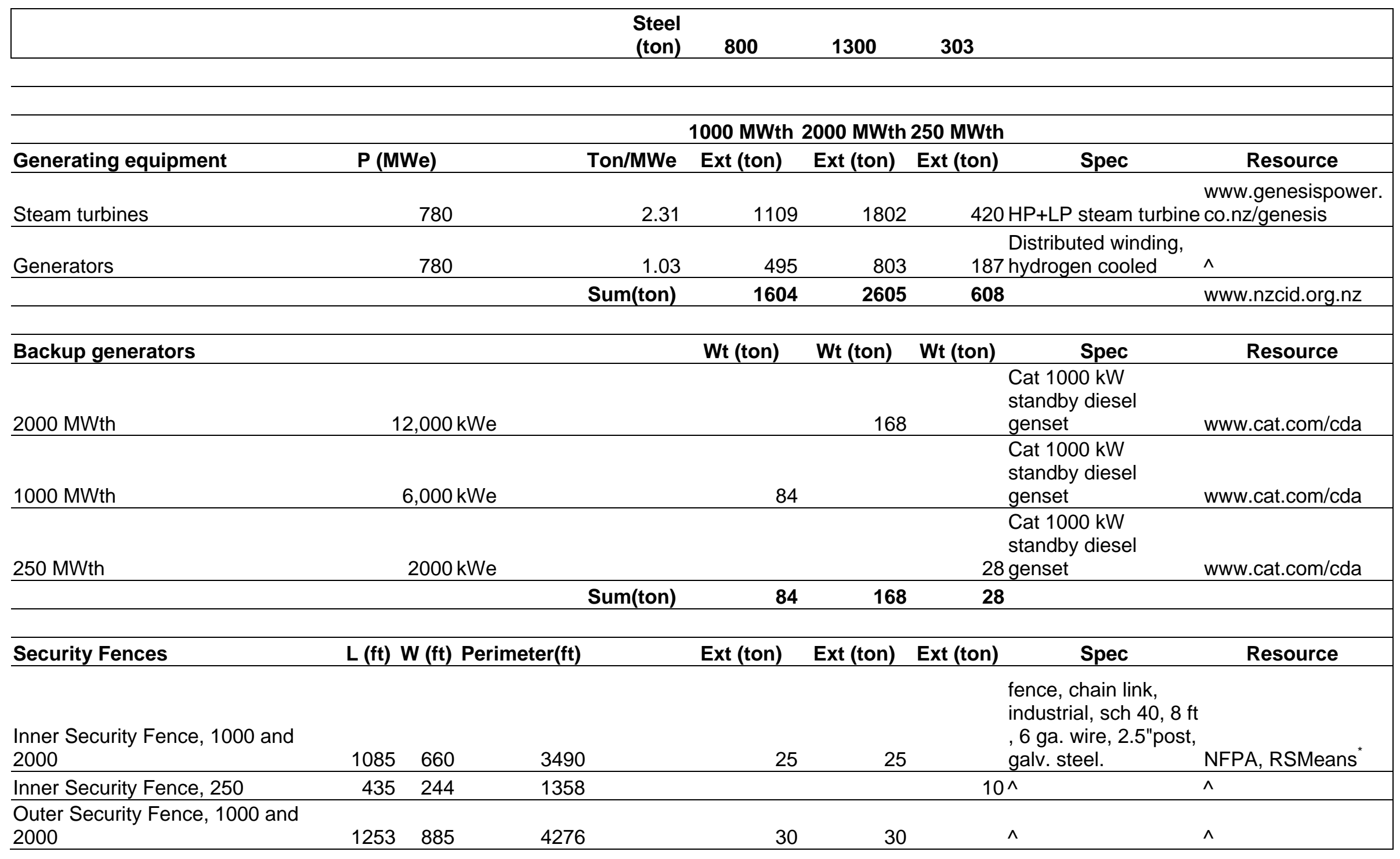


ANL-AFCI-183, Rev. 0.5

Argonne

Outer Security Fence, 250

$\begin{array}{rrr}616 & 394 & 2020 \\ 50 & 89 & 278\end{array}$

278

\begin{tabular}{|c|c|c|c|}
\hline & & & $14^{\wedge}$ \\
\hline & 2 & 2 & $2^{\wedge}$ \\
\hline um(ton) & 57 & 57 & 26 \\
\hline
\end{tabular}

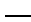

\begin{tabular}{|c|c|c|c|c|c|c|c|}
\hline Railroad spurs & 3.5 miles & ton/mile & & Ext (ton) & Ext (ton) & Ext (ton) & Resource \\
\hline Rail & 3.5 miles & ton/mile & 202 & 707 & 707 & $\begin{array}{r}\text { RE115 rail, pla } \\
707 \text { spikes,splices }\end{array}$ & www.akrailroad.com/ \\
\hline Plates & 3.5 miles & ton/mile & 33 & 116 & 116 & $116^{\wedge}$ & $\wedge$ \\
\hline Joints & 3.5 miles & ton/mile & 12.8 & 45 & 45 & $45^{\wedge}$ & $\wedge$ \\
\hline Bolts & 3.5 miles & ton/mile & 1.6 & 6 & 6 & $6^{\wedge}$ & $\wedge$ \\
\hline \multirow[t]{2}{*}{ Spikes } & 3.5 miles & ton/mile & 4.06 & 14 & 14 & $14^{\wedge}$ & $\wedge$ \\
\hline & & & Sum(ton) & 887 & 887 & 887 & \\
\hline
\end{tabular}

\begin{tabular}{|c|c|c|c|c|c|c|}
\hline Fire Protection & & & Ext (ton) & Ext (ton) & Ext (ton) & Resource \\
\hline Fire protect system, internal, 2000 & $206911 \mathrm{ft}^{2}$ & $0.92 \mathrm{lb} / \mathrm{ft}^{2}$ & & 95 & $\begin{array}{l}\text { Dry valve system, } \\
\text { extra hazard, }\end{array}$ & NFPA, RSMeans \\
\hline Fire protect system, internal, 1000 & $202361 \mathrm{ft}^{2}$ & $0.92 \mathrm{lb} / \mathrm{ft}^{2}$ & 93 & & $\wedge$ & $\wedge$ \\
\hline Fire protect system, internal, 250 & $66727 \mathrm{ft}^{2}$ & $0.92 \mathrm{lb} / \mathrm{ft}^{2}$ & & & $31^{\wedge}$ & $\wedge$ \\
\hline $\begin{array}{l}\text { Fire hydrant system, external, } 1000 \\
\text { and } 2000\end{array}$ & $6000 \mathrm{ft}$ & $24.5 \mathrm{lb} / \mathrm{ft}$ & 74 & 74 & $\begin{array}{l}12 " \text { main, hydrants, } \\
\text { PIV }\end{array}$ & $\wedge$ \\
\hline \multirow[t]{2}{*}{ Fire hydrant system, external, 250} & $3000 \mathrm{ft}$ & $24.5 \mathrm{lb} / \mathrm{ft}$ & & & $\begin{array}{l}\text { 12" main, hydrants, } \\
37 \text { PIV }\end{array}$ & $\wedge$ \\
\hline & & Sum(ton) & 167 & 169 & 67 & \\
\hline HVAC and Electrical & & & Ext (ton) & Ext (ton) & Ext (ton) & Resource \\
\hline Heating, 2000 & $206911 \mathrm{ft}^{2}$ & $1.12 \mathrm{lb} / \mathrm{ft}^{2}$ & & 116 & $\begin{array}{l}\text { hydronic, tube-fin, } \\
\text { electric boiler }\end{array}$ & RSMeans \\
\hline Heating, 1000 & $202361 \mathrm{ft}^{2}$ & $1.12 \mathrm{lb} / \mathrm{ft}^{2}$ & 113 & & $\begin{array}{l}\text { hydronic, tube-fin, } \\
\text { electric boiler }\end{array}$ & RSMeans \\
\hline Heating, 250 & $66727 \mathrm{ft}^{2}$ & $1.12 \mathrm{lb} / \mathrm{ft}^{2}$ & & & $\begin{array}{l}\text { hydronic, tube-fin, } \\
37 \text { electric boiler }\end{array}$ & RSMeans \\
\hline
\end{tabular}

Advanced Burner Reactor Facility 


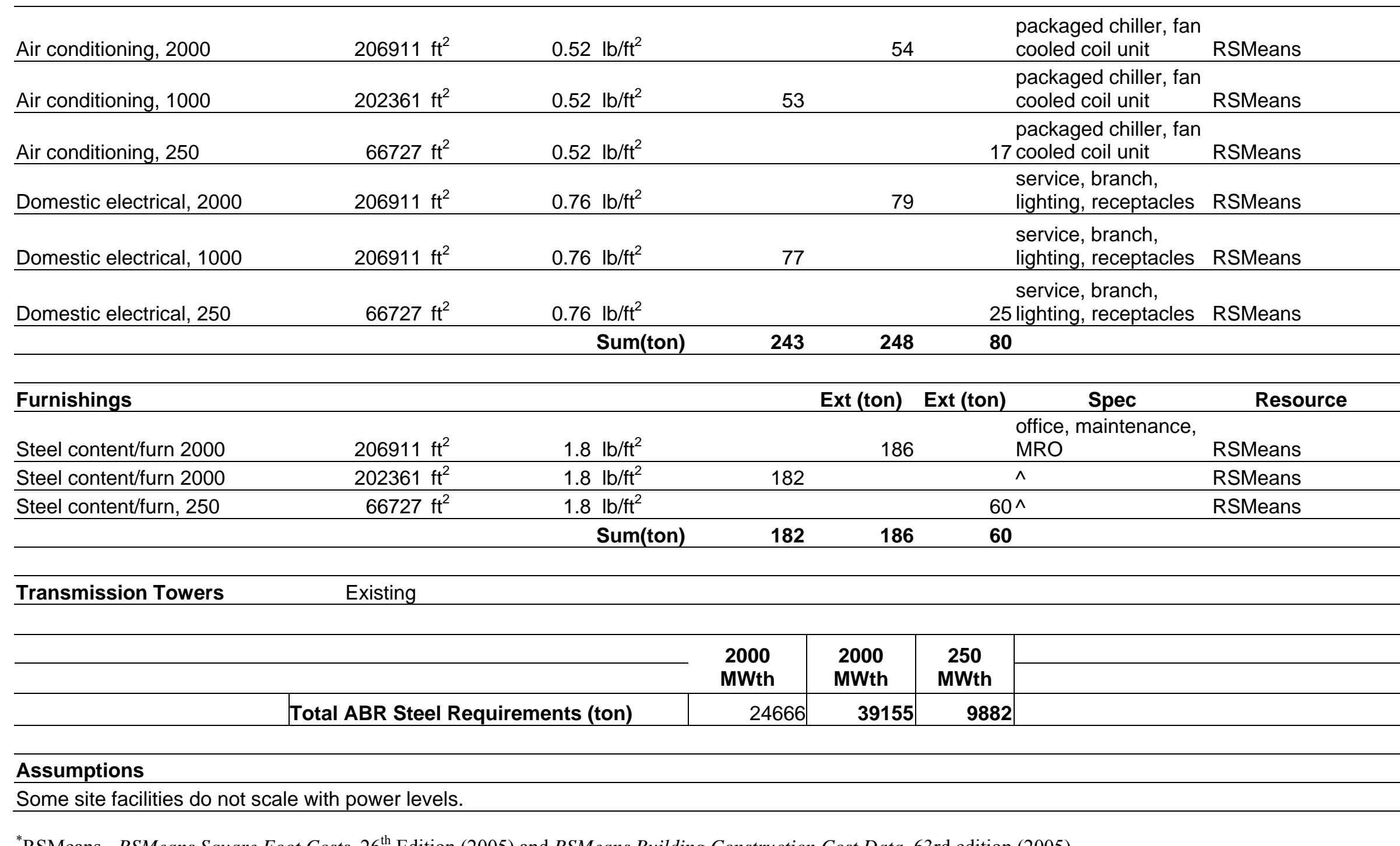

${ }^{*}$ RSMeans - RSMeans Square Foot Costs, $26^{\text {th }}$ Edition (2005) and RSMeans Building Construction Cost Data, 63rd edition (2005) 


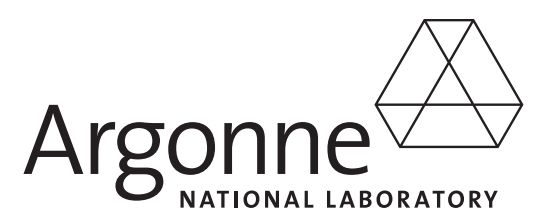

Nuclear Engineering Division

Argonne National Laboratory

9700 South Cass Avenue, Bldg. 208

Argonne, IL 60439-4842

www.anl.gov 